\title{
A BONA FIDES COMO ORIGEM DA BOA-FÉ OBJETIVA DO DIREITO BRASILEIRO•
}

\author{
Flávio Rubinstein \\ Mestrando em Direito Econômico-Financeiro pela \\ Faculdade de Direito da Universidade de São Paulo.
}

Resumo:

O presente trabalho analisa a teoria romana da bona fides. com o objetivo de fundamentar a tese de que hàveria verdadeiro princípio de boa-fé objetiva no Direito Romano, que pode ser considerado como origem da boa-fé objetiva do Direitu brasileiro.

Abstract:

This essay attempts to provide a comprehensive analysis of the roman theory of bona fides, in order to demonstrate that Roman Law had already foreseen a contractual good faith principle, which shall be regarded as the source of the Brazilian Law contractual good faith.

Unitermos: boa-fé objetiva; princípio jurídico; fides; bona fídes; bonac fídei iudicia; Direito Romano.

Keywords: good faith; fides; bona fides; bonac fidei iudicia; Roman Law.

I. Introdução.

A compreensão da boa-fé objetiva no Direito brasileiro encontra relevância acentuada nos dias atuais, em face da recente reestruturação do Direito privado pátrio, decorrente das implicações, ainda incipientes, do início da vigência do CC 2002.

Ademais, a proliferação no país de decisões judiciais que se valem do princípio da boa-fé objetiva, para fundamentar as soluções conferidas aos litígios.

- Monografia premiada como a melhor "Tese de Láurea", de 2004, do Departamento de Direito (ivil da FDUSP. Este trabalho foi recumendado a ser publicado nesta Revista pelo Professor Titular e Diretor desta Faculdade, Doutor Eduardo César Silveira Vita Marchi. 
coloca-se ao lado das alterações legislativas como fundamento para impulsionar o estudo do tema ora proposto.'

O exame do principio da boa-fé objetiva no Dircito privado desperta no espírito do estudioso, desde logo, três grandes preocupações: (i) a precisa delimitação de seu conteúdo; (ii) a determinação de sua operatividade, com a compreensão do papel do juiz. na sua aplicação; e (iii) a sua dimensão principiológica.

Propomo-nos, no presente estudo, a proceder a uma revisão históricodogmática da teoria romana da bona fides, ${ }^{2}$ princípio jurídico de criação romana que regia determinadas relações obrigacionais, tuteladas por juizos de boa-fé (bonae fidei iudicia).

Tal revisão visa a fundamentar a tese que defenderemos, qual seja a de que haveria verdadeiro princípio de boa-fé objetiva no Direito romano, em muitos aspectos semelhante ao princípio do Direito contemporâneo brasileiro, e que poderia ser considerado como fons et origo deste.

A compreensão da boa-fé objetiva romana, bem como de sua relação com a boa-fé objetiva pátria, poderá iluminar a discussão das quatro grandes preocupações acima referidas.

Importa observar que não se procederá à análise das questões práticas acerca do princípio da boa-fé objetiva no Direito pátrio, senão de maneira incidental e com o intuito de trazer luz à compreensão da dimensão romana da boa-fé objetiva.

Após a presente introdução (capítulo I), iniciaremos o estudo examinando a norma de boa-fé objetiva (capitulo II), passando à análise do princípio da

1. Dentre outras, podem ser citadas a título ilustrativo as seguintes decisões do Superior Tribunal de Justiça: ERESP n ${ }^{\circ} 168207 / S P, 24 / 04 / 2003$, Rel. Fernandu Gonçalves, DJ de 05/05/2003, p. 214; RESP n. 35682 1/RJ, 23/04/2002, Rel. Nancy Andrighi, DJ de 05/08/2002, p. 334; RESP n. 417927/SP, 21/05/2002, Rel. Nancy Andrighi, DJ de 01/07/2002, p. 339; RESP n. 272739/MG;, 01/03/2001, Rel. Ruy Rosado de Aguiar, RSTJ 150/398; ROMS n. 6183/MG, 14/11/1995, Rel. Ruy Rosado de Aguiar, LEXSTJ 82/90; AGA 47901/SP, 12/09/1994, Rel. Ruy Rosado de Aguiar, RSTJ 66/20; e RESP n. 32890/SP, 14/1 1/1994. Rel. Ruy Rosado de Aguiar, RSTJ 73/227.

2. Consoante será demonstrado no cap. IV infra, a boa-fé objetiva romana encontra-se desigrada nas fontes tanto como bona fides quanto como fides bona, conforme se fizesse refercincia, respectivamente, a uma noção jurídica substancial ou a uma cláusula do processo fonmular. Tendo em vista que em ambos os casos parece-se estar diante de uma mesma significação. apenas verificada cm contuxtos distintos, o uso de um ou outro termo seria equivalente. Optamos pela adoção uniforme de bona fides, porquanto esta denominação aproxima-se mais daquelas modernamente utilizadas nos países de idiomas latinos: boa-fe, bonne foi, buona fede e buena fe. 
boa-fé objetiva no Direito brasileiro (capítulo III) e da boa-fé no Direito romano (capítulo IV), de modo a fornecer subsídios para a conclusão (capítulo V).

II. Norma de boa-fé objetiva.

1. Contornos gerais.

Para que se proceda ao exame de a hipótese da origem da boa-fé objetiva moderna residir no Direito romano, é mister que se façam algumas considerações de cunho propedêutico acerca da concepção da noção ${ }^{3}$ de boa-fé objetiva.

A boa-fé objetiva caracteriza-se como produto do Direito, porquanto traduz um modo de decidir próprio de certa ordem sócio-jurídica. ${ }^{4}$ Entretanto, a referida noção deve ser compreendida como um dado da realidade valorado pelo Direito, e não meramente como criação arbitrária e puramente técnica deste.

Trata-se de algo presente também no tecido das relações sociais e apreciado pelo Direito para atribuir-lhe certos efeitos juridicos, por meio de matizes técnico-juridicas mais precisas, as quais implicam determinadas limitações. ${ }^{5}$

Dessa forma, não haveria que se falar em uma criação original do legislador, tampouco em uma absorção automática de dada realidade fática, mas em uma profunda conexão entre o Direito e a realidade orgânica na qual este se aplica, de modo a produzir uma noção jurídica com substrato real. A boa-fé objetiva coloca-se como elemento das relações humanas, o qual, ao incorporar-se ao Direito, recebe uma carga adicional que resulta das precisões técnicas necessárias. ${ }^{6}$

3. Parece ser apropriada a designação "noção", e não "conceito", uma vez que, conforme observa Eros R. Gral'. O Direito Posto e o Direito Pressuposto, 4. ed., São Paulo, Malheiros, 2002, p. 195-205, os conceitos são idéias universais e atemporais. enquanto as noções são idéias temporais e históricas, homogêneas ao desenvolvimento das coisas e. portanto, passiveis de interpretação.

4. Cf. A. M. R. Menezes Cordeiro, Da Boa-fé no Direito (ivil, Coimbra, Almedina, 2001, p. 18.

5. Cf. P. BONFANTE, Essenza della "bona fides" e suo rapporto colla teoria dell'errore in Scritti Giuridici Varii, vol. II, Torino, Unione Tipografico, 1916. p. 708 ss: J. DE LOS MOZOS, El principio general de la buena fe - Sus aplicaciones prácticas en el derecho civil español, Barcelona, Bosch, 1965, p. 15.

6. Cf. D. M. Ferreira RuBio, La Buena Fe El principio general en el derecho civil, Madrid, Montecorvo, 1984, p. 80. Dessa forma, a norma de boa-fé objetiva assemelhar-se-ia a outras incorporaçäex da realidade pelo Direito que recebem matizes técnico-juridicas, tal qual sucede com a "morte cerebral", marco juridico que confere à noção de "morte" um diferente signficado, matizado para permitir a prática de transplantes de órgàos. 
Assim, não obstante seja a boa-fé objetiva dotada de natureza jurídica, ela apresenta uma profunda vinculação com fatores éticos, morais e axiológicos, campos nos quais há uma marcada disparidade de critérios ${ }^{7}$

Nesse contexto, evitam-se, em geral, tentativas de apresentar uma definição lapidar da noção de boa-fé objetiva, conduta justificada em face da riqueza e do alcance que apresenta. ${ }^{8}$

Com efeito, a boa-fé objetiva não é definida de modo preciso pelo ordenamento jurídico, sendo encontrada quando a lei remete para os "princípios" "ditames" ou "limites" da boa-fé ou, simplesmente, determina que o indivíduo proceda "de boa-fe"

Em que pese a complexidade da noção de boa-fé objetiva, podem sur apontadas na doutrina manifestações que buscam descrever seu conteúdo. notadamente no âmbito do Direito das obrigações.

De modo geral, parece correto afirmar que a norma de boa-fé objetiva compreende um conjunto de prestações, direitos e deveres que, nos planos do conteúdo do contrato e da execução da obrigação, incumbe às partes, com base na exigência genérica de comportamento segundo um critério de retidão. ${ }^{9}$

Dessa forma. a atuação conforme à boa-fé objetiva pressupõe que a parte de uma relação contratual observe comportamento que corresponda à legítima expectativa do outro contratante. ${ }^{10}$

7. ('f. D. M. Ferreira Rubio, La Buena Fe cit. (nota 7 supra), p. 77; Cf. P. Bonfantz Esserza cit. (nota 6 supra), p. 718 ;

8. Cf. A. M. R. Menezes Cordeiro, Da Boa-fé cit. (nota 5 supra), p. 18:D. M. Ferreira Rubio. La Buena Fe cit. (nota 7 supra), p. 77. No mesmo sentido, CAIO MÁRIO DA SII VA PEREIRA, Boa-fe-I in ESD II (1977). p. 487. afirma sobre a boa-fé que "se ninguèm Ihe contesta a existência na quasetotalidade dos atos da vida civil, se ninguèm lhe nega os efeitos - ao apurá-la e defini-la, vinga certa inconsistência"

9. Cf. M. T AL.AMANCA, Lu 'bonu fides' nei giuristi romani: "Leerformel» e valori dell 'ordenamento in Il ruolo della buona fede oggetiva nell' esperienza giuridica storica e contemporanea. vol. IV, Luigi Garofalo (org.), Padova, CEDAM, 2003, p. 17-19; ORL.ANDO GOMES, Obrigaçōes, 12. ed., Rio de Janeiro. Forense, p. 89-90. Parte da doutrina costuma apontar no conteúdo desse princípio a presença de dois deveres, um positivo e um negativo. O primeiro seria um dever de lealdade (sentido negativo), que impediria comportamentos desleais das partes, e o segundo um dever de cooperaçào entre os contraentes (sentido positivo). Nesse sentido. Francisco Amaral. A Boa-fé no Processo Romano in R'vista de Direito Civil 78 (1996), p. 196.

10. Cf. ORLANDO GOMES, Obrigações cit. (nola 10 supru), p. 90. 
O princípio da boa-fé objetiva teria uma função de auxílio à prática judicial. traduzindo-se como critério de orientação para a interpretação e integração dos contratos. Teria, ainda. o papel de limitar o exercício dos direitos subjetivos, em contraposição ao princípio da autonomia das partes. ${ }^{11}$

Com base nessas linhas iniciais já é possivel constatar que a boa-fé objetiva distingue-se da chamada "boa-fé subjetiva", presente, sobretudo nas relações de direitos reais. ${ }^{12}$

Nesse sentido, M. Talamanca afirma que não parece ser atualmente discutível - nem no plano da lógica do sistema do Direito e das categorias que o compõem. nem sob o ponto de vista da aplicação concreta - que a boa-fé subjetiva c a boa-fé objetiva sejam dois esquemas operativos diversos. A primeira poderia ser caracterizada como o estado psicológico de um sujeito que age (por meio de um comportamento), ou encontra-se em uma determinada posição jurídica, ignorando lesão (efetiva ou potencial) a um interesse alheio juridicamente protegido; seria, em essência. o contraposto da má-fé. ${ }^{13}$

A boa-fé objetiva, por seu turno, caracteriza-se como regra de conduta cujo estado psicológico é irrelevante. Esta boa-fé desenvolve-se de modo dinâmico, podendo ser compreendida como "norma de correção", não guardando relação alguma. portanto. com o modelo da boa-fé subjetiva, o qual se coloca de modo estático no plano da consciência do sujeito. ${ }^{14}$ Trata-se de algo exterior ao sujeito, que se lhe impõe, nada tendo a ver, assim, com estados relativos ao sujeito de direitos. ${ }^{15}$

Por fim. cumpre observar que a contraposição entre boa-fé objetiva e boa-fé subjetiva não se confunde com uma outra, entre boa-fé psicológica e ética. uma

11. Cf. Francisco amaral., A Boa-fé cit. (nota 10 supra), p. 196.

12. Cf. ORLANDO GOMES, Obrigações cit. (nota 10 supra), p. 90; M. TALAMANCA, La 'bona fides cit. (nota 10 supra), p. 9 ss; e A. M. R. MENEzES CORDI IRO. Da Boa-fé cit. (nota 5 supra). p. 24.

13. Cf. La 'bona fides' cit. (nota 10 supra), p. 9-10. No mesmo sentido posiciona-se A. M. R. MENEZES CORDFiro, Da Boa-fé cit. (nola 5 supra), p. 24.

14. Cf. M. TAL AMANCA, La 'bona fides' cit. (nola 10 supra), p. 14-15.

15. Cf. A. M. R. MENEzes CORdeiro. Da Boa-fé cit. (nola 5 supra). p. 24. Em relação ao fato de os ordenamentos juridicos comumente se valerem de remissões genéricas à boa-fé objetiva, cl. tb. M. TalamanCA, La 'bona fides' cit. (nota 10 supra). p. 12. 
vez. que ambos estes vetores estão presentes na boa-fé subjetiva. ${ }^{16} \mathrm{O}$ primeiro traduz um estado fático de mera ignorância, e o segundo um estado de ignorância valorado pelo Direito, com reflexos práticos em que releva, apenas, se for desculpável. ${ }^{17}$

\section{Dimensão principiológica.}

Com base nas considerações acerca da boa-fé objetiva acima apresentadas, proceder-se-á ao exame do enquadramento da referida noção como princípio jurídico. Para tanto, faz-se mister expor breves considerações propedêuticas relativas ao papel dos princípios no sistema do Direito.

Inicialmente, cumpre apontar que, consoante demonstra G. CARRIÓ, a expressão "princípio jurídico" é polissêmica, podendo-se apresentar nada menos do que 11 distintas significações para tal expressão. ${ }^{18} \mathrm{~A}$ doutrina, nesse cenário, tem demonstrado intensas preocupações com a conceituação e aplicação dos princípios, apontando a relevância desta categoria normativa para o ordenamento juridico. ${ }^{19}$

Para os fins deste estudo, é despicienda a análise das diversas siginificações de "princípio" bastando reconhecer a importância dos princípios como "fins imanentes da ordem juridica e social, reguladores teleológicos da atividade interpretativa" ${ }^{20}$ e identificá-los como espécie do gênero "norma jurídica" 21

Resulta claro o papel fundamental exercido pelos princípios no sistema do Dircito, uma vez que são eles elementos inerentes à coerência e racionalidade deste

16. A inclusão dos prismas psicológico e ético na boa-fé subjetiva é defendida, dentre outros, por Otávio Moreira Guimarāes, A Boa Fé no Direito Civil Brasileiro, São Paulo. RT, 1938, p. 25-28. Em sentido contrário: NELSON NERY JÚNIOR, Contratos no Código Civil Apontamentos (jerais in O Nowo Código Civil - Estudos em Homenagem ao Professor Miguel Reale. Domingos Franciulli Netto, Gilmar Ferreira Mendes e Ives Gandra da Silva Martins Filho (orgs.), São Paulo, LTr, 2003.

17. Cf. A. M. R. Menezes Cordeiro, Da Boa-fé cit. (nola 5 supra), p. 24.

18. Cf. Nolas sobre derecho y lenguage, 4. ed., Buenos Aires. Abeledo-Perrot, 1994, p. $210-12$.

19. Cf. HI 'MBerto ÁvILA, Teoria dos Principios - Da definição à uplicução dos principios juridicos, São Paulo. Malheiros, 2003; e EROS. R. GRAU, Ensaio e Discurso sobre a Interpretação/Aplicação do Direito, São Paulo, Malheiros, 2003.

20. Cf. Tércio Sampaio Ferraz JR., Introdução ao Éstudo do Direito - Técnica, Decisão, Dominação, 2" ed., São Paulo, Atlas, 1994, p. 292.

21. Cf. Eros R. GRAu, Ensaio sobre a Interpretação/Aplicação do Direito, 2. ed., São Paulo, Valheiros, 2003 p. 45 . O autor apresenta extensas considerações acerca das diferenças entre regras e principios. 
sistema, bem como vetores de direcionamento da interpretação das demais normas que o constituem.

Todavia, o reconhecimento da importância e do papel dos princípios no ordenamento não basta para diferenciá-los das regras jurídicas. Para proceder a esta distinção, a doutrina costuma apontar que o princípio jurídico é dotado, dentre outras, das seguintes particularidades: (i) generalidade própria, porquanto comporta uma série indefinida de aplicações; (ii) aplicação dependente da ponderação do conteúdo que apresenta; (iii) convivência conflitual, e não antinômica; (iv) permissão do balanceamento de valores e interesses; e (v) conteúdo composto por standards (parâmetros). ${ }^{22}$

Parece correto afirmar que a boa-fé objetiva apresenta as particularidades caracterizadoras dos princípios. De fato, tal noção jurídica é estabelecida para regular situações indetermináveis, e não apenas determinados atos ou fatos previstos na norma. Seu conteúdo, ademais, é composto por standards que remetem a padrões de comportamento segundo critérios de retidão e lisura, de modo que no caso concreto deve ser considerado e sopesado o conjunto de interesses e valores presentes. Como resultado, a norma de boa-fé objetiva deve ser aplicada com base na ponderação do referido conteúdo, devendo-se em cada caso concreto examinar sc é ou não justificada tal aplicação e, em caso afirmativo, de que modo isso deve ser feito. ${ }^{23}$

Essa dimensão principiológica traz como relevante implicação a inviabilidade de falar-se em uma boa-fé objetiva em sentido absoluto ${ }^{24}$ compreendida

22. Cf. EROS R. GRAL, Ensuio cit. (nola 22 supra), p. 163 ss.

23. Com efeito, a boa-fé objetiva tem sido amplamente reconhecida como principio jurídico pela doutrina. Nisse sentido posicionam-se R. CARDILLI, La buona fede come principio di diritto dei contrati in Roma e America - Dirillo romano comune 13 (2002), p. 185; D. M. FERREIRARUBIO, La buenafe cit. (nota 7 supra), p. 147; MARIA HElEna DINIZ, Curso de Direito Civil Brasileiro, vol. III, 17. ed., São Paulo, Saraiva, 2002, p. 39; Francisco Amaral, A Boa-fé cit. (nota 8 supra), p. 199; e ORLANdo GOMES, Obrigações cit. (nota 10 supra), p. 90. Em sentido contrário posiciona-se NELSON NERY JÚNYUR, Contratos cit. (nota 17 supra), p. 430, para quem a boa-fé objetiva caracteriza-se como regra jurídica.

24. Nesse sentido, M. TALAMANCA, La 'buna fides cit. (nola l0 supra), p. 18; J. DELOSMOzos, El principio cit. (nota 6 supra), p. 16 ss; LUIz OLAVO BAPTISTA, A Boa-fé nos Contralos Internacionais in Revista de Direito Bancário, do Mercado de Capitais e da Arbitragem 20 (2003), p. 28; Em sentido contrário posiciona-se D. M. Ferreira RuBlo, La Buena Fe cil. (nota 7 supra), p. 137 ss. 
como um princípio geral e universal, tendo em vista que os princípios jurídicos de cada ordenamento jurídico são próprios de tal ordenamento. ${ }^{25}$

De fato, conforme observa M. Talamanca, a boa-fé objetiva compreende valores que não são fixados ab aeterno e in aeternum, o que comprovaria se tratar de principio resultante de determinada experiência histórica e, sobretudo, do trabalho dos cultores do Direito. ${ }^{26}$

Estar-se-ia diante de critérios que são essencialmente variáveis, seja sobre a base das diferentes valorações subjetivas - presentes na sociedade - em relação à conduta de retidão, seja em função das mutações do caso concreto, quando um comportamento idêntico é colocado em cenários completamente diversos. ${ }^{27}$

Dessa forma, a norma de boa-fé objetiva prevê um modelo de comportamento esperado de um sujeito correto, leal e honesto (o bonus et diligens paterfamilias da tradição romanística). ${ }^{28}$ consoante o entendimento de uma dada sociedade em certo momento histórico. ${ }^{29}$

Assim, há que se estudar cada ordenamento jurídico para determinar se consta a inclusão de princípio da boa-fé objetiva, razão pela qual se justifica um atento exame do Direito pátrio, o qual será realizado abaixo. ${ }^{30}$

3. Relevância do estudo da boa-fé do Direito romano.

A boa-fé objetiva está, atualmente, envolta em um quadro de mitificação. Não obstante seja objeto de utilização alargada, apresenta contornos pouco conhecidos,

25. Com efeito, conforme observa EROS R. GRAU, Direito cit. (nota 4 supra), p. 71, não deve ser reconhecida a existência de princípios gerais de Direito, senão apenas de princípios gerais do Direito. pois eles são descobertos ou não no interior de cada ordenamento jurídico.

26. C.f. I.a 'bona fides'cit. (nota 10 supra), p. 19.

27. Cf. M. TAlamanCA, La 'bona fides'cit. (nota 10 supra), p. 19.

28. Cf. M. TALAMANCA, La 'bona fides' cit. (nota 10 supra), p. 13; e ORLANDOGOMES, Obrigaç̃óes cit. (nota 10 supra), p. 90.

29. Cf. J. C. Moreira Alves, O Novo Código Civil Brasileiro e o Direito Romano - Seu Exame quanto às Principais Inovações no tocante ao Negócio Jurídico in O Novo Código Civil - Estudas em Homenagem ao Professor Miguel Reale, Domingos Franciuli Netto, Gilmar Ferreira Mendes e Ives Gandra da Silva Martins Filho (orgs.), São Paulo. LTr. 2003, p. 121.

30. O referido exame será apresentado no cap. III infra. 
caracterizando-se como noção vaga, carregada de história e rica em implicações emotivas. $^{31}$

Esse vácuo tende a ser preenchido lingüisticamente, com metáforas sucessivas destinadas a suplantar as carências substanciais que a noção de boa-fé objetiva apresenta. Nesse diapasão, não faltam tentativas de assimilá-la a inúmeras locuções juridicas também dotadas de ampla abstração, como "justiça" "eqüidade" e "equilibrio" De outra parte, também por vezes procura-se ver na boa-fé objetiva uma remissão a complexos ordenadores metajurídicos, como a Ética, a Moral e o Direito Natural. $^{32}$

Importa observar que a natureza juscultural da boa-fé objetiva traz a necessidade de assumi-la como criação humana, fundada, dimensionada e explicada em termos históricos. $^{33}$

As investigações científicas realizadas a partir do início do século XX revelam uma cristalização do debate acerca da boa-fé em teorias que transpõem para a História, de modo significativo, muitas das questões ainda hoje acolhidas ao instituto. Dentre estas teorias, destacar-se-ia, precisamente, a que busca na bona fides os alicerces da boa-fé objetiva contemporânea. ${ }^{34}$

Esse quadro revela a necessidade de compreender, a partir da criação da bona fides como realidade jurídica no Direito Romano, os componentes históricos que a marcaram. O estudo da bona fides pode fornecer valiosos elementos necessários à correta delineação do conteúdo. alcance e finalidade de tal instituto no sistema jurídico pátrio.

Nesse passo. cumpre reproduzir a sugestão de F D. Busnelli, concernente a "un saluduble buño em las aguas incontaminadas del derecho romano para depurar el concepto de buena fe de todas las escorias que lo han hecho ambiguo y recuperar plena concienciu de los contenidos irrenunciables de su nucleo" 35

31. Cf. A. M. R. MENezes Cordeiro, Da Boa-fé cit. (nota 5 supra). p. 41.

32. Cf. A. M. R. MEnezes Cordeiro, Da Boa-fé cit. (nota 5 supra). p. 45.

33. Cf. A. M. R. MEnezes Corneiro, Da Boa-fé cil. (nola 5 supra). p. 18.

34. Cf. A. M. R. MEnezes Cordeiro, Da Boa-fé cit. (nota 5 supra). p. 54.

35. Cf. Notas em tema de buena fe y equidad, in Roma e America Dirito romano comunc $13(2002)$. p. 120. 
O recurso à disciplina da boa-fé no Direito Romano não visa à elaboração de um histórico exaustivo da boa-fé objetiva brasileira, mas apenas a identificar na tradição romanista uma dada contiguração do instituto que se pretende demonstrar ser a origem deste.

III. Princípio da boa-fé objetiva no Direito privado brasileiro.

1. Breve histórico normativo.

A legislação de Direito privado do Império e do primeiro centenário da República foi marcada pela ausência de normatização explícita de uma cláusula geral de boa-fé objetiva aplicável em matéria contratual.

No curso desse longo período, merece destaque a tímida iniciativa intentada pelo legislador do Código Comercial, de 1850, que trouxe disposição acerca da boa-fé como princípio interpretativo dos contratos comerciais. Com efeito, dispunha o art. 131 deste diploma que "sendo necessário interpretar as cláusulas do contrato, a interpretação, além das regras sobreditadas, será regida sobre as seguintes bases: Ia inteligência simples e adequada, que for mais conforme à hoafé e ao verdadeiro espirito e natureza do contrato, deverá sempre prevalecer à rigorosa e restrita significação das palavras (...)" A amplitude deste dispositivo, todavia, jamais teria sido reconhecida pela doutrina e pela jurisprudência, tendo em vista que sua aplicação como critério de intepretação dos contratos comerciais foi demasiadamente escassa. ${ }^{36}$

Subseqüentemente, o CDC prestigiou a norma da boa-fé objetiva em diversos dispositivos. ${ }^{37}$ transformando-a em norma de conduta apta a abandonar de vez

36. Cf. Cibele Pinheiro Marçal Cruz e TuCCl, Teoria Geral da Bna-Fé Ohjetiva in Revista do Advogado 68 (2002), p. 107.

37. O art. $4^{\circ}$, III, do CDC incluiu expressamente a boa-fé objetiva entre os principios básicos do Direito do consumidor. Ademais, pelo art. 5I, incisos I a XVI, deste diploma. havendo relação de consumo serão nulas de pleno direito quaisquer cláusulas leoninas, abusivas ou desleais. Outrossim, podem ser consideradas referências implicitas à boar fé objetiva os arts. 30 (dever de incluir na oferta toda informação ou publicidade suficientemente precisa), 46 (dever do fornecedor de assegurar ao consumidor cognoscibilidade e compreensibilidade prévias do conteúdo do contrato) e 48 (exigência da continuidade da ofirta de componentes e peças de reposição, após o contrato de aquisição do produto). 
o subjetivismo que representava um obstáculo insuperável à efetiva tutela dos direitos do consumidor. ${ }^{38}$

No campo da codificação do Díreito Civil pátrio, é no Esbôço de Teixeira de Freitas (1855) que se percebe a presença do princípio da boa-fé objetiva pela primeira vez. ${ }^{39}$ Apesar dos antecedentes históricos, o CC 1916 contemplou apenas a boa-fé em sua acepção subjetiva, não possuindo dispositivo expresso cuidando de norma geral de boa-fé objetiva, mencionada somente de forma incidental.

Com efeito, as numerosas remissões expressas à boafé existentes no CC $1916,{ }^{40}$ salvo algumas esparsas e casuísticas exceções, ${ }^{41}$ importam uma apreciação subjetiva da conduta. Isto explica, aliás. o fato de a boa-fé ter sido, nas décadas que sucederam à promulgação de tal diploma. examinada preponderantemente em relação aos Direitos Reais.

A partir da década de 1940. os doutrinadores incumbidos de elaborar projetos de reformulação da legislação de Direito privado passaram a propor a adoção pelo Direito pátrio de expressa menção à boafé objetiva. Neste sentido, as iniciativas de resgate de referido princípio podem ser constatadas no Anteprojeto de Código das Obrigações de 1941, no Projeto de Código das Obrigações de 1965 e no Anteprojeto de Código Civil de $1972 .^{42}$

38. Nesse sentido manifesta-se A. JUNQueIRA DE AzEVEDo, A Boa Fé na Formação dos Contratos in Revista de Direito do Consumidor 3 (1992), p. 79, para quem "(...) a recente lei de proteção ao consumidor, que, por sua amplitude é denuminada 'Código de Proteção do Consumidor (Lei $n^{a} 8$. 078/90) tem o principio da boa fé refletido em inúmeros de seus artigos. Aqui, Irata-se, na verdade, da boa fé objetiva que interessa à formulação do contrato, isto é. a boa fé como regra (objetiva) de conduı" Partilham da mesma opinião MARIA HELENA DINIZ, Curso cit. (nola 24 supra), p. 39; e ORLANDOCOMES, Obrigações cit. (nota 10 supra), p. 90.

39. De fato, o art. 1.954 do Esboço previa a exigência de boa-fé como regra de conduta.

40. Neste sentido, observem-se as disposiçóes dos arts. 109, 112, 221, 255, 490, 491, 500, 510, 511 , $514,516,549,550,551,612,619,622,933,935,968,1.002,1.072,1.073,1.045,1.272,1.318 .1 .321$. $1.382 .1 .404,1.443,1.477$ e 1.507 .

41. O diploma de 1916 fazia menção à boa-fé objetiva no art. 1.404, o qual disciplinava o contrato de sociedade ("A renúncia de um dos sócios só dissolve a socicdade quando feita de boa-fé, em tempo oportuno e notificada aos sócios dois meses antes"), e no art. 1443, que regulava o contrato de seguro ("O segurado e segurador são obrigados a guardar no contrato a mais estrita boa-fé e veracidade, assim a respeito do objeto, como das circunstâncias e declarações a eles concernentes). Ademais, como bem aponta A. JUNQUEIRA DE AZEVEDO, A Boa-fé cit. (nota 39 supra), p. 81 . o art. 94 trazia a contrcoio senszh, uma regra concernentc ao dever de informar sobre fato ou qualidade essencial, norma esta que poderia ser vista como um desdobramento especifico do princípio da boa-fé objetiva.

42. C. Miguel Reale, A Boa-fé no Código Civil in Revista de Dircito Bancário, do Mercado de Capitais e da Arbitragem 21 (2003), p. 11. 
Foi a redação final do Projeto de Lei n. 634-B ("Projeto de Código Civil" o qual, após sucessivas revisões e décadas de tramitação no Congresso, foi promulgado em janeiro de 2002, por meio da Lei n. 10.406) que conferiu à boa-fé objetiva a amplitude expressiva de sua normatização sob a forma de um princípio geral. $^{43}$

No C.C 2002, o princípio é uma constante, observado com nitidez em três momentos distintos: no art. 113, ${ }^{44}$ exercendo função interpretativa; no art. $187,{ }^{45}$ com função de controle dos limites do exercício de um direito; e no art. $422,{ }^{46}$ no qual consubstancia exigência genérica de retidão na relações obrigacionais. Há, ainda, outras menções incidentais ao principio, como aquela feita pelo art. $765^{47}$ o qual acentua e qualifica a boa-fé objetiva na contratação do seguro.

Especial relevo merece o conteúdo do art. 422, o qual prevê a chamada "cláusula geral da boa-fé" admitindo o alcance do princípio aos comportamentos in contraendo (celebração contratual, abrangendo os comportamentos que a anteccdem) e post factum finitum (execução do contrato, com todos os comportamentos resultantes da natureza deste). ${ }^{48}$

De qualquer forma, parece correto afirmar que os mencionados dispositivos do CDC e do C.C. 2002, não obstante as matizes que apresentam, fazem semılhante referência a uma exigência genérica de conduta de boa-fé objetiva pelas partes nas relações obrigacionais. Esta exigência deve tomar por parâmetros os usos e costumes da sociedade contemporânea brasileira, no que concerne à retidão esperada do homem médio em suas condutas.

43. CI. TERESA P. DL A. T. NEGREIROS, Fundamentos para uma Interpretaçâo Constitucional do Principio da Boa-Fé, Rio de Janeiro, Renovar, 1998, p. 74.

44. "Os negócios juridicos devem ser interpretados conforme a boa-fé e os usos do lugar de sua celubração"

45. "Também comete ato ilicito o titular de um direito que, ao exercê-lo, excede manifestamente os limites impostos pelo seu fím cconômico ou social, pela boa-fí ou pelos bons costumes"

46. "Os contratantes são obrigados a guardar, assim na conclusão do contrato, como em sua execução, os principios de probidade e boa-fé"

47. "O segurado e o segurador são obrigados a guardar na conclusão e na execução do contrato a mais estrita boa-fé e veracidade, tanto a respeito do objeto como das circunstâncias e declarações a ele concurnentes" O conteúdo deste dispositivo é análogo ao do art. 1.443 do CC 1916.

48. Cf. Paulo luiz Netto Lobo, Princípios Sociais dos Contratos no Código de Defesa du Consumidor e no Novo Código Civil in Revista de Direito do Consumidor 42 (2002), p. 194. 
2. Natureza e conteúdo.

Consoante se pode depreender do histórico normativo acima apresentado, encontra-se atualmente positivada no Direito privado brasileiro verdadeira norma de boa-fé objetiva, geradora de um dever de retidão do tráfego negocial. ${ }^{49}$

Essa normatização, parece assentado admitir, teria adotado a estrutura de princípio jurídico, tendo em vista que prescreve aplicações genéricas e dependentes da ponderação de valores e interesses, compondo-se por parâmetros interpretativos. ${ }^{50}$

A dimensão principiológica da boa-fé objetiva do Direito brasileiro confere-lhe a caracteristica de consubstanciar verdadeira medida do conjunto de regras juridicas aplicáveis às obrigações, existindo ao mesmo tempo como cânone hermenêutico e como norma criadora de deveres e limitações ao exercício de direitos subjetivos. $^{51}$

Em sua função hermenêutica, a boa-fé objetiva atua como critério de interpretação de todos os momentos e fases do vínculo obrigacional, permitindo que as peculiaridades do caso concreto sejam consideradas, de modo a flexibilizar a vontade das $_{\text {partes. }}{ }^{52}$ Esta flexibilização implica a prevalência da intenção, inferida da declaração de vontade das partes, sobre o sentido literal da linguagem. ${ }^{53}$

Outrossim, o papel hermenêutico da boa-fé objetiva também apresenta um prisma integrativo, colocando-se como cânone hábil ao preenchimento de lacunas

49. Cf. JUDITH H. MARTINS-COSTA, O Adimplemento e o Inadimplemento das Obrigações no Novo Código Civil e o seu Sentido Ético e Solidarista in O Novo Código Civil - Estudos em Homenagem ao Professor Miguel Reale, Domingos Franciulli Netto, Gilmar Ferreira Mendes e Ives Gandra da Silva Martins Filho (orgs.), São Paulo, LTr, 2003. p. 351 ss.

50. Acerca da caracterização dos princípios jurídicos, cf. cap. 1.2 supra.

51. Cf. Judith H. Martins-Costa, A Boa-fé no Direito Privado. Sistema e Tópica no Processo Obrigacional, São Paulo, RT, 1999, p. 427 ss. O referido papel ambivalente do princípio da boa-fé objetiva é ressaltado também por EROS R. GRAU no prefácio à obra da autora.

52. Cf. Judith H. Martins-Costa, A Boa-fé cit. (nota 52 supra). p. 429.

53. Este papel da boa-fé objetiva encontra-se expressamente previsto no art. 113 do CC 2002 , transcrito no cap. III.I supra. 
nas relações contratuais, tendo em vista que estas representam situações e eventos jurídicos e fáticos - nem sempre previstos ou previsiveis pelas partes. ${ }^{\varsigma 4}$

Desse modo, nota-se que o princípio da boa-fé objetiva no Direito brasileiro está intimamente ligado à interpretação contratual e ao interesse social de segurança nas relações jurídicas. ${ }^{55}$

No que concerne à atuação da boa-fé objetiva voltada à criação de deveres jurídicos. observe-se que estes se referem à adoção de determinados comportamentos por ambas as partes. os quais são indispensáveis ao exato processamento da relação obrigacional. Estes comportamentos. variáveis em conformidade com as circunstâncias do caso concreto, possibilitam a satisfação dos interesses globais de ambas as partes. Como exemplos, podem ser citados os seguintes deveres: (i) de aviso e esclarecimento; (ii) de cuidado, previdência e segurança; (iii) de informação; (iv) de omissão e segredo; e (v) de proteção e cuidado com a pessoa e o patrimônio da contraparte. ${ }^{56}$

Em relação ao papel de limite ao exercício de direitos subjetivos, deve-se notar que a boa-fé objetiva apresenta-se como norma que não admite condutas dotadas do condão de contrariar o mandamento de as partes agirem com retidão. A referida limitação ao exercício de direitos contrários à boa-fé objetiva mostra-se particularmente operante no campo da resolução contratual. ${ }^{57}$

Ambos esses papéis da boa-fé objetiva - de criação de deveres e de limitação de direitos podem ser compreendidos como prismas de uma mesma exigência, qual seja a de as partes agirem com retidão. De fato, parece correto afirmar que a conduta esperada do bonus pater familias prevê deveres e limitações a direitos. porquanto se fundamenta em parâmetros comportamentais voltados ao êxito da relação obrigacional em benefício das duas partes.

54. Cf. Judith H. Martins-Costa, A Boa-fé cit. (nota 52 supra), p. 428. Conforme ubserva a autora. a boa-fé objetiva permite qualificar comportamentos que não resultam nem das cláusulas pactuadas e nem de expressa e cogente disposição legal, comportamentos estes que são essenciais à própria salvaguarda do pressuposto fáticu do contrato e à plena produção dos efeitos que a este correspondem.

55. Cf. Maria Helena Diniz, Curso cit. (nota 24 supra), p. 39.

56. Cf. Judith H. MARTins-CosTa, A Boa-fé cit. (nola 52 supra), p. 437 ss: e Maria Hi LENA DNIZ. Curso cit. (nota 24 supra), p. 39.

57. Cf. Judith H. MARTINS-CostA, A Boa-fé cit. (nola 52 supra), p. $455 \mathrm{ss.}$ 
Conforme inserida no ordenamento jurídico pátrio, a norma de boa-fé objetiva, para que seja fixado o conteúdo preciso da conduta esperada do bonus paterfamilias, pressupõe a atuação da atividade judicante no caso concreto. ${ }^{58}$

Com efeito, deve o juiz, ao examinar o caso concreto, estabelecer a conduta que seria adotada pelo homem médio brasileiro contemporâneo, tendo em vista as circunstâncias e nuances presentes no caso. Uma vez estabelecido esse modelo criado pelo magistrado para a situação sob análise, cumpre confrontá-lo com o comportamento efetivamentc apresentado pelas partes: havendo contrariedade. estar-sea diante de uma conduta ilícita. pois em desacordo com a boa-fé objetiva. ${ }^{59}$

Uma vez apresentado esse breve exame dos contornos do princípio da boa-fé objetiva do Direito pátrio, proceder-se-á ao estudo da bona fides, o qual terá como início a análise da noção de fides.

IV. Boa-fé do Dircito romano.

1. "Fides"

1.1. Considerações iniciais.

A origem da noção da boa-fé romana está envolta em uma névoa de mistério até os dias de hoje. Em que pese a dificuldade de apontar uma teoria prevalecente em relação ao tema, parece correto afirmar que os especialistas, majoritariamente, concordam acerca do fato de ser a boa-fé romana herdeira - sob os pontos de vista lingüístico e conceitual - de uma noção mais vasta e antiga, porém menos precisa, qual seja a da fides. ${ }^{60}$

O exame da natureza primitiva e das linhas subseqüentes de evolução da fides, portanto, deve ser considerado como inerente ao estudo da boa-fé romana. Não

58. Cf. RUY ROSADO AGI'IAR JÚNIOR, Extinção dos Contratos por Incumprimento do DevedorRésolução, 2. ed., Rio de Janeiro, Aide, 2003, p. 247-248.

59. Cf. RUY ROSADO Agl'IAR JÚNIOR, Extinção cit. (nota 59 supra), p. 247-248.

60. Cf. P. D. SENN, Buona fede nel dirillo romano in Civ. 2 (1998), p.130; FrANCTSCOAMARAL, A Boa-fé cit. (nota 8 supra). p. 196; e M. KASER, Das römisches Privatrecht, 1968, trad. Pont. de Samuel Rodrigues e Ferdinand Hämmerle. Direito Privado Romano, Lisboa, Fundação Calouste Gulbenkian, 1999 , p. 50 ss. 
obstante, consoante observa A. M. C. Menezes Cordeiro, tal exame tem merecido um certo desinteresse científico, motivado pela escassa documentação histórica dos períodos romanos arcaico e pré-clássico. ${ }^{61}$

Cientes dos obstáculos que marcam o exame da fides, procuraremos traçar os principais contornos desta noção, notadamente no que concerne à sua significação, aplicação e natureza. Para tanto, tomaremos como ponto de partida a constatação da relevância da fides na cultura romana.

Sob a ótica de M. Bretone, a prática e o cultivo de todas as formas de virtude teriam permitido ao povo romano a evolução verificada entre uma modesta origem e a grandeza que acabou por marcá-lo. Neste cenário, destacar-se-ia, em comparação com qualquer outra virtude, a fides, cultivada maximamente e considerada sagrada, tanto nas relações privadas quanto nas públicas. ${ }^{62}$

Ademais, Francisco Amaral nota que as idéias morais e políticas do povo romano, em parte herdadas dos gregos, são a contribuição cultural mais significativa por ele legada. Para o romanista, poder-se-ia afirmar que o mundo contemporâneo define seus próprios padrões comportamentais por meio da adesão ou rejeição - tácitas ou implícitas - àqueles valores. Uma das principais idéias de tal natureza seria, precisamente, a fides. ${ }^{63}$

Nesse cenário, não causa surpresa o fato de a fides ter sido uma idéia central - com multiplicidade de matizes - do pensamento político, jurídico e social romano, constituindo um dos valores mais genuínos e operantes para o homem romano. $^{64}$

61. Cf. Da Boa-fé cit. (nora 5 supra), p. 53 . O autor entende. inclusive, que o tema está condenado a palco de discussões herméticas e especulativas, reservadas a iniciados, crescentemente se distanciando da problemática atual da boa-fé.

62. Cf. Storia del diritto romano, 1987, trad. port. de Isabel Teresa Santos e Hossein Seddighzadeh Shooja, História do Direito Romano, Lisboa, Estampa, 1990, p. 104.

63. Cf. A Boa-fé cit. (nola 8 supra), p. 199.

64. Cf. J. PARICIO, Historia y fuentes del derecho romano, Madrid, Centro de Fstúdios Ramon Areces, 1988, p. 97. 


\subsection{Significação.}

Consuante afirma A. Carcaterra. a análise etimológica do termo fides indica que este teria bases na língua grega, siginificando "liame" ou "vínculo" Ao lado deste significado objetivo há um outro subjetivo, com referência seja a quem está vinculado, seja a quem espera o respeito ao vínculo. ${ }^{65}$

D. Nörr observa que a noção de fides é tradicionalmente traduzida por "confiança", "honradez", "lealdade", "fidelidade" "garantia" "crédito" "confiabilidade" etc. Para o autor, haveria dois motivos que fundamentariam ser "confiança" a tradução mais adequada. Primeiramente, esta seria a análise filológica mais convincente, consoante apontado por especialistas. Ademais, esta palavra evocaria aos juristas modernos o princípio da confiança (Vertrauensgrundsatz), de estrutura muito semelhante à fides romana. ${ }^{66}$

Este entendimento, contudo, é incompatível com o de P. Bonfante, para quem seria impossível defender que a fides apresentava, na linguagem verdadeiramente romana, o sentido do termo alemão Glaube (confiança), o qual somente surgiria com o advento do Cristianismo e do Direito Canônico. Para o romanista, não seria Glaube a significação fundamental da noção, mas sim Treue (lealdade), motivo pelo qual a primeira designação deve ser evitada, de modo a não provocar confusão conceitual. ${ }^{67}$

De outra parte, V. Arangio-Ruiz, ao verter a obra clássica de F. Schulz para o italiano, prefere usar a palavra fedeltà, considerando-a a mais apropriada para denotar os diversos significados da fides. como fídúcia, fé e a própria "fidelidade" 68

P Bonfante critica também essa posição, afirmando que se deve rejeitar a conveniência de traduzir fides por "fé" ou outras noções similares, pois a palavra fé não teria conservado o significado pleno do termo fides. A expressão "prestar fé" não

65. Cf. Intorno ai bonac fidei iudicia, Napoli, Jovene, 1964, p. 194-195.

66. Cf. Die Fide im römischen Völkerrecht. 1991, trad. usp. de R. Domingo, La fides en el derecho internacional romano, Madrid, Fundacion Seminario de Derecho Romano Ursicino Alvarez, 1996, p. 16.

67. Cf. P. BONFANTE, Essenza cit. (nota 6 supra), p. 719. No mesmo sentido, F. SCHULZ, Prinzipien des römischen Rechts, 1934, trad. it. de Vicenzo Arangio-Ruiz, I principii del diritto romano, Finenze, Sansori, 1946, p. 193.

68. Cf. 1:. SCHuL7, Prinzipien cit. (nola 68 supra). p. 193. 
corresponderia a fidem preastare e, tampouco, "perder fé" equivaleria a fidem perdere. ${ }^{69}$

Assim, observa-se na doutrina romanística clara discrepância provocada pelas diversas tentativas de tradução de fides. Tendo em vista essa realidade, preferimos usar a expressão original latina em lugar de procurar substituí-la por alguma palavra do léxico pátrio, a qual, ademais, dotar-se-ia de denotação apenas aproximada ao significado original da fides.

Em verdade, pensamos que buscar as possíveis interpretações para o alcance de fides importa mais do que almejar equipará-la a termos modernos. Nesse diapasão, intentaremos apresentar as diferentes interpretações que o termo romano comporta.

Antes que se proceda a tal exame. contudo, releva apresentar a advertência de D. Nörr acerca da interpretação da noção de fides. A correta determinação desta, de forma semelhante à que caracteriza as noções contemporâneas, requer a consideração de uma pluralidade de elementos. ${ }^{70}$

Assim, deve-se atentar para a extrema complexidade da fides, a qual, no atual estado das conhecimento científico, não pode ser reduzida a uma noção unitária ${ }^{71}$ Qualquer definição da fides apenas plantaria uma significação elementar do termo, tendo em vista que haveria outras tantas, impossibilitando qualquer propósito de exaurir seu sentido. ${ }^{72}$

1.3 Prismas semânticos.

O problema da extrema complexidade da noção de fides encontra em diversos estudos romanísticos uma interessante solução voltada à compreensão de seu

69. Cf. P. Bonfante. Essenza cit. (nota 6 supra), p. 719.

70. Cf. Die Fide cit. (nota 67 supra), p. 36.

71. Cf. P. D. SFNn, Buona fede cil. (nolu 61 supra), p. 130; e J. GAL DEMET, 'Fides 'e 'buna fides' in Labeo 9 (1963), p. 240.

72. Cf. F. SCHUlZ, Prinzipien cil. (nora 68 supra), p. 193. 
conteúdo: a idéia de que a fides apresenta diversos prismas semânticos, os quais devem ser analisados de forma complementar, uma vez que interagem entre si. ${ }^{73}$

Os diversos prismas semânticos da fides basear-se-iam em elementos históricos, a revelar distintos aspectos relacionados à vida romana. Fstes aspectos referir-se-iam, nomeadamente: (i) à religião; (ii) ao poder; c (iii) à manutenção da palavra dada. ${ }^{74}$

A presente análise iniciar-se-á pelo estudo do prisma semântico relativo à religião.

De início, importa notar que a fides, como os demais institutos e idéias motrizes da época originária romana, é fortemente marcada por um elemento religioso.

Esse elemento, conforme observa A. M. C. Menezes Cordeiro, estaria documentado em latitudes diversas, quais sejam: (i) na XII Tab., ${ }^{75}$ ao cominar sanções de cunho religioso ao patrão que defraudasse a fides do cliente; (ii) no culto da deusa Fides; e (iii) na análise dos poderes extensos atribuídos ao pater e nas fórmulas iniciais da sua limitação. ${ }^{76}$

Dentre as latitudes apontadas, pode-se considerar como mais relevante e, portanto, merecedora de exame mais detido - aquela do culto à deusa Fides, a qual representava a fides e era reconhecida tanto pelos cidadãos romanos (cives), quanto pelos peregrinos (non cives). ${ }^{77}$

73. Cf. A. M. R. MENEzes Cordeiro, Da Boa-fé cit. (nota 5 supra), p. 54 ss; J. PARiClo, Historia cit. (nola 65 supra), p. 97 ss; P. D. SENN, Buona fede cit. (nota 61 supra), p. 130 ss; Franclsco AMARAI, A Boa-fé cit. (nota 8 supra). p. $199 \mathrm{ss;}$ M. KASER, Das römisches cit. (nola 61 supra), p. 50 s; G. Grosso, Buona fede (premesse romanistiche) in ED 5 (1959), p. 661 ss: e J. GAUDEMET, 'Fides' cit. (nota 72 supra), p. 242-243.

74. Em que pese o fato - presumivel em si de as denominaçöes dos prismas semânticos da fides diferirem de autor para autor, de modo geral revolvem em torno dos três aspectos apontados. Cf. Franciscu AmARAL, A Boa-fé cit. (nola 8 supra), p. 199 ss; A. M. R. MENeZes CoRDEIRO, Da Boa-fé cit. (nota 5 supra), p. 55 ss; P. D. SFNN, Buona fede cit. (nota 6/ supra), p. 130-131; e J.GAUDEMET, 'Fides cit. (nota 72 supra), p. 241.

75. 8,21 .

76. Cf. Da Boa-fé cit. (nota 5 supra), p. 55.

77. Cf. Francisco Amaral, A Boa-fé cit. (nota 8 supra). p. 199, M. KASER, Das römisches cit. (nota 61 supra), p. 50. 
Ainda que o fato de a primeira manifestação da fides remontar à origem de Roma scja consenso entre os estudiosos, certos autores, como é o caso de L. Lombardi Vallauri, recusam-se a reconhecer um nexo entre a fides e o antiquíssimo culto da deusa Fides, e por isso não concedem muito espaço ao clemento religioso da noção. ${ }^{78}$ A communis opinio, entretanto, reconhece uma relação precisa entre o referido culto e a noção da fides. ${ }^{79}$

A deusa Fides, invocada na celebração de negócios entre cidadãos e entre cidadãos e peregrinos, velava pelo bom cumprimento de tais negócios, protegendo os cumpridores e castigando os faltosos ${ }^{80}$

Conforme relata D. Nörr, o culto à deusa Fides era inicialmente celebrado como uma parte do culto a Júpiter, o deus dos juramentos. Mais tarde, já na fase de personificação do deuses (em meados do séc. III a.C.), erigiu-se uma estátua da Fides, e a ela se dedicou um templo próprio no ('apitolium, ${ }^{81}$ em cujas paredes eram colocados tratados internacionais. ${ }^{82}$ A cada ano, três sacerdotes, em um carro puxado

78. Cf. Recensão a Dieter Nörr, Die Fides im röınischen Volkerrecht in IURA 62 (1991), p. 183.

79. C. A. CARCATERRA, Dea Fides e 'fides - Storia d'una laicizzazione in SDHI 50 (1984), pp.199 ss; J. GAudemet, 'Fides cit. (nota 72 supra), p. 241 ; A. M. R. MENEZES CorderRo. Da Boa-fé cit. (nota 5 supra), p. 55; D. NÖRR, Die Fide cit. (nota 67 supra), p. 61; G. Grosso, Buona fede cit. (nota 74 supra), p. 66I; J. PARICIO, Historia cit. (nota 65 supra), p. 97: e P. D. SINN, Buona fede cit. (nota 61 supra), p. I 30 .

80. Cf. Francisco Amaral, A Bou-fé cit. (nota 8 supru), p. 199.

81. Cf. Cic. De off. 3, 29, 104. No mesmo sentido posicionam-se G. Grosso, Buonafede (premesse romanistiche) in ED 5 (1959), p. 661; e A. M. R. MENEZES CORDEIRO, Da Boa-fécit. (nota 5 supra), p. 54. De outra parte, A. CARCATERRA, Dea Fides cit. (nota 80 supra), p. 202-207, discorda desta alegada autonomia. Para o autor, o culto à deusa Fides fazia parte do mito de Numa Pompilio (antigo rei de Roma, cuja existência não pôde ainda ser verdadeiramente comprovada), o qual representava um arquétipo contraposto ao de Rômulo, conhecido por ser belicoso e fratricida - de um Estado construído sobre os fundamentos da pax (paz) e da concordia (harmonia).

82. A relação entre a fides e os tratados internacionais merecerá considerações mais aprofundadas no cap. IV.I .6 infra, quando se examinará o prisma funcional da fides relativo às relações externas de Roma 
por dois cavalos, eram levados para realizar um sacrificio a Fides, ${ }^{83}$ no qual se cobria a mão direita (manus dextera) ${ }^{84}$ da estátua, símbolo máximo da lealdade à palavra dada. ${ }^{85}$

Nesse passo, resta claro que o ius iurandum (fórmula sacral) do ritual da Fides invocava a deusa para testemunhar em favor da veracidade dos vínculos assumidos pelo povo Romano, fossem estes próprios de tempos de guerra ou de paz, de modo a assegurar que as condutas dos indivíduos se adequassem à palavra por eles dada. $^{86}$

Nessa referência estava implícita - na instauração de uma relação - uma discricionariedade e, juntamente, no ato de apertar a mão, um vínculo desta discricionariedade, a qual, segundo afirma G. GROSSO, apresenta vastas oscilações. Estas vão desde a discricionariedade pura, que é caracteristica do se dedere in fidem, como rendição à discrição -.. e que, em certas interpretações, parece admitir e justificar até uma crueldade desumana - até uma garantia de benevolência generosa e o respeito a certos limites, que vinculavam precisamente à própria fides, ao antigo fidei numen, promessa e garantia. ${ }^{87}$

A concepção religiosa da fides teria se desenvolvido em duas linhas: nas relações internacionais entre Estados ou entre cidadãos de Estados distintos (fides

83. Cf. D. NORR, Die Fide cit. (nota 67 supra), p. 61. Consoante relata A. CARCATERRA, Dea Fides cit. (nota 80 supra), p. 208 ss, a carruagem, ao levar os três sacerdotes lado a lado, simbolizava a união destes em torno do ideal de respeito aos liames instaurados pelos romanos, ideal este tão bem divinizado na Fides. Cada sacerdote (sacerdos) representava um de três códigos rituais distintos: o sacerdas martialis era o emblema da guerra vitoriosa, mas não agressiva; o sacerdos quirinalis era o símbolo da riqueza econômica; e o sacerdos dialis caracterizava-se como uma figura representativa da imagem divina. A celebração conjunta dos três sacerdotes, e dos fins político-religiosos que eles simbolizavam, indicava que se tratava de um ritual marcado pela paz e harmonia. Quanto ao fato de serem dois os cavalos que puxavam a carruagem dos saccrdotes, estar-se-ia diante do emblema da convivência de valores opostos, como conquista bélica e paz.

84. Dai o hábito dos contratantes de dar um aperto das mãos direitas (dextrarum porrectio) para conferir solenidade à promessa, gesto que, mesmo após o desaparecimento do culto à deusa Fides, permaneceu como sinal de confiança mútua, origem remota e significado da forma de cumprimento comumente adotada pelos povos ocidentais. Cf. FRANCISCO AMARAL, A Boa-fécit. (nota 8 supra), p. 199.

85. Cf. G. Grosso, Buona fede cit. (nota 74 supra), p. 661: e J. PARIClO, Historiacit (nota 65 supra), p. 97. Já A. CARCATERRA, Dea Fides cit. (nota 80 supra), p. 211-212, discorda dessa afirmação, observando que, nas cerimônias religiosas. eram os sacerdotes yue tinham de estar com as mãos direitas cobertas com tecidos de lã branca, de forma a simbolizar idéias de paz. (daí a coloração neutra dos tecidos e o material destes, proveniente de ovelhas) e evitar contatos impuros com a estátua. A mão direita da Fides, por seu turno, deveria ustar descoberta, precisamente por ser o seu símbolo máximo.

86. Cf. A. CarCaTl-RRA, Dea Fides cit. (nota 80 supra), p. 214.

87. Cf. Buona fede cit. (nota 74 supra), p. 661. 
publica, fides populi Romani) e nas relações privadas. Nas duas perspectivas, para F. Amaral, a fides atuava como poder. ${ }^{88}$ Cumpre, nesse passo, examinar o prisma semântico da fides relacionado à noção de poder.

Esse aspecto da fides manifustava-se, sobretudo, na proteção ao mais fraco. Todavia, desenvolvia-se também em relações de igualdade, quando passava a exprimir o respeito ao cumprimento das promessas e à palavra dada, a fidelidade ao convencionado. ${ }^{89}$

Surge na fides, assim, a noção de poder, uma virtude própria do individuo mais forte em uma relação jurídica. A propósito, poderiam ser apontadas a fides do tutor, a fides do juiz e a fides do patrono; o pupilo, os litigantes e o cliente, respectivamente, estavam submetidos ao poder dos sujeitos precitados. ${ }^{90}$

A. M. C. Menezes Cordeiro, relativamente ao prisma semântico em tela (denominado "fides-fato" pclo autor), observa que seria ele despido de conotações religiosas ou morais, podendo ser identificado como uma noção de garantia, associada a alguns institutos (como o da clientela). ${ }^{91}$

J. Gaudemet traça interessante plano evolutivo do prisma semântico de poder da fides. A plebe, insatisfeita com a discricionariedade da fides dos patrícios, engajou-se em vitoriosa luta contra ela, levando-a ao declínio e à conseqüente substituição por uma "fides melhor" 92 Esta luta teria sido marcada pcla XII Tab., que limitou os poderes do tutor e do patrão ${ }^{93}$ e, posteriormente, pela lei Poetelia-Papiria

88. Cf. A Boa-fé cit. (nota 8 supra), p. 199. No mesmo sentido posiciona-se P. D. SENN, Buona fede cit. (nota 6l supra), p. 130.

89. Cf. Cic. De off. 1, 7, 23. No mesmo sentido. cf. FrAncisco Amaral. A Boa-fécit. (nota 8 stpra), p. $199-200$

90. Cf. J. PARICIO, Historia cit. (nota 65 supra), p. 97.

91. Cf. Da Boa-fé cit. (nota 5 supra), p. 55.

92. Uma das causas das lutas internas presentes desde o início da história de Roma era, precisamente, o poder sobre o cidadão-cliente que o magistrado e o patrono rucebem $\mathrm{um}$ virtude da fides.CF. P.D.SENN, Buona fede cit. (nola 61 supra), p. 130. A relaçĩo de clientela será melhor explorada no cap. IV.I.5 infra.

$93.8,21$. 
(326 a.C.), a qual suprimiu os rigores do nexum. ${ }^{94}$ De outra parte, a arbitrariedade da fides teria persistido por muito mais tempo nas relações entre povos. ${ }^{95}$

Dessa forma, do sentido original, o prisma do poder, no início caracterizado por ser teoricamente discricionário, brevemente passou a significar proteção, e logo fidelidade e lealdade (com especial referência ao "mais forte"). ${ }^{96}$ Esta evolução, como já observado, teria primeiramente se processado no plano interno, mais tarde estendedo-se às relações internacionais.

De outra parte, a referência à noção de "poder" no conteúdo da fides é considerada inaceitável por A. Carcaterra. Os exemplos adotados pelos autores que defendem tal inclusão seriam, em sua opinião, interpretações equivocadas das fontes. Assim, a fides não poderia ser considerada uma noção que tradu $\measuredangle$ uma situação de total dependência, de modo que poder e fides seriam elementos conceitualmente distintos. ${ }^{97}$

A fides, para o referido romanista, indicaria verdadeiro dever, até no caso da tutela. Neste sentido, várias fontes poderiam ser citadas, com destaque para a seguinte: "fidei ac verecundiae curatorum convenit" 98 Substancialmente, a fides ("in fidem venire" "in fide esse"), não significaria somente "estar em poder". nem apenas "potestas"; significaria, antes, "estabelecer uma relação de confiança" 9y

Entendemos que os posicionamentos dos romanistas acima apontados não são incompatíveis entre si, podendo ser harmonizados. De fato, parece correto aceitar a referência à noção de poder na fides em algumas situações da vida dos

94. O nexum era um empréstimo, realizado por um ato formal per aes et libram (ato em que, na presença das partes, do objeto e de 5 testemunhas, bem como de uma balança e de seu portador, pronunciavam-se certas palavras solenes e praticavam-se outros atos simbólicos), no qual se transfere a propriedade do objeto - normalmente dinheiro emprestado - e cria-se para o devedor a obrigação de devolver outro tanto do mesmo gênero, qualidade e quantidade. O devedor passa a responder pessoalmente, inclusive com o próprio corpo, pulo débito. Cf. THOMAS MARKY, Curso Elementar de Direilo Romano, $8^{a}$ ed., São Paulo, Saraiva, 1995, p. 199-120.

95. Cf. J. GAUDEMET, 'Fides' cit. (nota 72 supra), p. 242.

96. Cf. J. PARICIO, Historia cil. (nola 65 supra), p. 97.

97. Cf. Paul. 38 ad ed., D. 26, 1, 1, pr. Em relação ao tema, cf. A. CARCATERRA, Intomo cit. (nota 66 supra), p. 195. J. GAUDEMET, 'Fides' cit. (nota 72 supra), p. 243, por seu tumo, admite a aplicabilidade do prisma semântico de poder referente à fides, mas reconhece que a diferença fundamental entré tal prisma e outras relações de poder não resta muito evidente.

98. Cí. Ulp. 35 ad ed., D. 26, 7, 5, 6 .

99. Cf. A. CARCATERra, Intorno cit. (nota 66 supra), p. 196. 
romanos. não como representação delimitada de seu conteúdo, mas como um dos prismas semânticos inerentes à fides.

Assim, tal referência à noção de poder, não obstante surgida com o sentido de submissão discricionária, teria evoluído para traduzir o estabelecimento de relações de proteção e fidelidade, entre o "mais forte" e o "mais fraco", implicando verdadeira garantia. Estas considerações podem ser comprovadas por meio da análise dos prismas funcionais da fides nas relações internas e externas de Roma, a qual consta abaixo. $^{100}$

Uma vex examinados os prismas semânticos da fides referentes à religião e ao poder, passaremos a estudar o terceiro e último prisma, talvez o mais significativo de todos em relação à formação da boa-fé objetiva romana. Trata-se da noção de manutenção da palavra dada.

Mais do que mero fato, a exigência de manutenção da palavra dada seria sintoma de um desenvolvimento conceitual incipiente, implicando o sentido de dever, ainda quando não recebida pelo Direito. Desde o momento em que a "garantia" expressa pela noção de poder passou a residir na qualidade de uma pessoa, a fides passou a ser dotada também de matizes morais. ${ }^{101}$

Diferentemente das relações de poder, passa-se a estar diante de um curso histórico particular nas relações privadas, no qual. ao contrário, acentuar-se-iam os limites que expressavam o respeito à fides. Nascia, assim, um princípio ético que se desenvolvia por meio de relações estabelecidas sob um plano de igualdade. ${ }^{102}$

$\mathrm{Na}$ base deste novo valor da fides, afirmava-se o prisma semântico da fides que, consoante observa Francisco Amaral, poderia ser compreendido como a lealdade à palavra dada, considerado a idéia central do pensamento político-jurídico das relações do Direito. ${ }^{103}$ Assim, de acordo com M. Kaser, o fundamento da fides seria o dever de cumprir a palavra que vale para todos os homens, sem disitinção de nacionalidade. ${ }^{104}$

100. Cf. caps. IV.1.4 a IV.1.5 infra.

101. Cf. A. M. R. Menezes Cordeiro, Da Boa-fé cit. (nota 5 supra), p. 56.

102. Cf. G. Grosso. Buona fede cit. (nota 74 supra), p. 661.

103. Cf. A Boa-fé cit. (nota 8 supra), p. 199.

104. Cf. Das römisches cit. (nola 6I supra), p. 50. 
Este fundamento, nas palavras de P. Bonfante, era para o romano aquilo que para nós são a honra e a virtude -- valores diversos, pois mais extrínsecos e materiais, do que honor c virtur - e signiticava a mais austera observância do próprio dever na relação com os semelhantes. ${ }^{105}$

Analogamente, F. Schulz, ao afirmar que a fides era definida na Antigüidade como a existência de palavra dada (fit quod dicitur). coloca-a como uma das facetas da constantia (invariabilidade), que na visão dos romanos perfaria a virtude central do homem. Para ilustrar seu raciocínio, o romanista transcreve uma expressão do idioma inglês, a qual corresponderia ao referido sentido da fides: take a course and stick to it! (escolha um caminho e atenha-se a ele). ${ }^{106}$

As fontes literárias confirmam a relação, tão cara para os romanos, entre a ficles e a manutenção da palavra dada. ${ }^{107}$ De fato, Cícero afinna categoricamente que a fundação da iustitia é a fides, a qual são a verdade e a fidelidade a promessas e acordos, motivo pelo qual os romanos deveriam seguir o caminho dos estóicos - que diligentemente investigavain a etimologia das palavras - e aceitar sua declaração de que a fides assim se chama porque o que é prometido deve ser cumprido. ${ }^{108}$ Assim, para Cícero, o fundamento da fides reside na atitude perseverante e veraz em relação a tudo quanto foi dito e convencionado.

A exigência de manutenção da palavra dada pode ser compreendida como a necessidade de respeitar vínculos ou promessas, tendo em vista que está na base dos juramentos e das estipulações da vida romana. ${ }^{109}$

Com efeito, P. D. Senn observa que o dever de ater-se à palavra dada pode ser considerado tanto como designação do liame instaurado por uma promessa (in

105. Cf. Essenza cit. (nota 6 supra), p. 719. Opinião semelhante é apresentada por A. MONIEL, Buona fede in $N N D 2$ (1998), p. 602, o qual cita numerosas fontes literárias romanas.

106. Cf. F. SCHulz, Prinzipien cit. (nota 68 supra), p. 193-194.

107. Cf. D. NÖRR, Die Fide cit. (nola 67 supra), p. 18: e A. CARCATERRA, Intorno cit. (nola 66 supra), p. 195.

108. Cf. De off. I, 7, 23, "Fundamentum autem est iustitiae fides, id est dictorum conventorumque constantia et veritas. Ex quo. quamquam hoc videbitur forlasse cuipiam durius, tamem audeamus imitari Stoicos, qui studiose exquirunt, unde verba sint ducta, credamusque. quia Fiat, quod dictum est, appellatain fidem"

109. Cf. J. PARICIU. Historia cit. (nota 65 supra). p. 97. 
fide stare, fidem frangere) quanto como respeito pelo vinculo obrigacional instaurado (dictorum conventorumque constantia et veritas). ${ }^{110}$

De qualquer forma, o prisma semântico da fides de manutenção da palavra dada demonstra, conforme nota $F$. Schulz. a seríssima responsabilidade com a qual as promessas e vínculos cram ainda adotados em uma época histórica em que o sentimento religioso já havia perdido parte de seu peso originário. Mesmo quando o homem incauto não mais temia a pena divina, continuava ele a estar vinculado pela fides. ${ }^{111}$

Esta constatação encontra-se comprovada nos textos de Cícero, quando este afirma que a fides, inclusive a dos juramentos, deveria ser observada ainda quando extraída com uso de violência, ${ }^{12}$ bem como mantida freqüentemente frente aos inimigos. $^{113}$

Relevante notar que no mundo antigo o recurso à palavra era muito mais freqüente do que nós seríamos capazes de admitir. O texto escrito desempenhava um papel apenas secundário, realidade bem representada na metáfora - sugerida por $M$. Bretone da partitura de uma sinfonia. ${ }^{114}$

Pode-se adotar como sintese do prisma semântico de manutenção da palavra dada da fides a afirmação de F. Schulz, para quem a fides implicaria o respcito ao vínculo assumido, tanto em relação à manutenção da palavra dada, quanto ao comportamento correspondente ao costume das pessoas de bem. ${ }^{115}$

\subsection{Prismas funcionais.}

A partir da análise semântica da fides, com a apreciação conjunta de seus prismas diversos. seria possivel inferir teorias bem fundamentadas sobre a gênese e o desenvolvimento do instituto.

110. Cf. Buona fede cit. (nota 61 supra). p. 131.

111. Cf. Prinzipien cit. (nola 68 supra), p. 198.

112. Cf. De off. 3, 30, 110, "at non debuit ralum esse, quod erat actum per vim-Quasi vern forti viro vis posit adhiberi"

113. Cf. De off. 3, 29, 107, "fidesque iuris iurandi saepe cum hoste scrvanda"

114. Cf. Storia cit. (nota 63 supra), p. 107.

115. Cf. Prinzipien cit. (nota 68 supra). p. 198. 
Tendo em vista a forte interação entre os prismas apresentados, parece inevitável deduzir-se que a fides deve ser vista como uma teia de conotações, a qual não poderia ser reduzida a uma noção precisa, confirmando sua já alegada complexidade conceitual.

Assim, parece assentado que a fides representava um vínculo de garantia, no qual se pressupunha a necessidade de manter a palavra dada, com níveis de representação sacros e, mais tarde, éticos e morais. ${ }^{116}$ Constatar-se-ia, dessa forma, um processo de evolução paulatina da fides, ao final do qual esta não mais se caracterizava como idéia mística e religiosa, mas como uma noção laica dotada de conteúdo técnico. ${ }^{117}$

Essa gradual laicização levanta um importante questionamento, referente à natureza da fides, nomeadamente no que diz respeito à possibilidade de tratar-se de uma noção jurídica.

O exame filológico da fides, não obstante tenha apresentado extrema valia para a compreensão genérica do conteúdo da referida noção, é insuficiente para o estudo da mencionada questão. Desse modo, faz-se necessário recorrer ao estudo da fides pelos prismas funcionais das suas manifestações concretas.

De acordo com F Schulz, são numerosas na vida romana as relações marcadas pela fides, vínculos pressupostos pelo Direito Romano e sem os quais se torna impossivel avaliá-lo. ${ }^{118}$

Em virtude do fato de a fides ter apresentado diversos desenvolvimentos e direções, bem como diversas formações de significado, tem-se como resultado que suas interferências resultaram em complexo quadro histórico. ${ }^{119}$

O campo de aplicação da fides é subjetivo a gera controvérsias, uma vez que entra em conflito com outras noções como, por exemplo, a potestas e o

116. Cf. A. M. R. Menezes Cordeiro, Da Boa-fé cit. (nota 5 supra). p. 59.

117. Cf. A. Carcaterra. Dea Fides cit. (nota 80 supra), p. 200-201; 234. Como observa o autor, ainda não está claro para os estudiosos o modo exato pelo qual se deu o processo de laicização da ficles. Uma hipótese plausível, sugerida pelo próprio romanista italiano, seria a de que tal processo configuraria um desdobramento da própria laicização do Direito romano, o qual em certo momento deixou de ser monopólio dos pontífices.

118. Cf. Prinzipien cit. (nota 68 supra), p. 200; No mesmo sentido, G. Grosso, Buona fede cit. (nota 74 supra), p. 662.

1 19. Cf. G. Grosso, Buona fede cit. (nota 74 supra). p. 661. 
dominium $^{120}$ De forma geral, pode-se afirmar que a fides era a projeção de aplicações concretas prévias, situadas em duas áreas distintas: nas relações internas próprias da cidade e dos habitantes desta - e nas externas, da cidade com outros povos. ${ }^{121}$

\subsection{Fides no Plano Interno.}

No plano interno, diversas relações jurídicas são marcadas pela fides, podendo-se apontar, dentre outras, a clientela, tutela, curatela, adoção e fidúcia. Como denominador comum para todos estes institutos, pode-se apontar que se tratam de atos de homens livres que renunciam, em maior ou menor grau, à sua liberdade. ${ }^{122}$

Dentre todos estes vínculos, merecem destaque os de clientela. ${ }^{123}$ instituição social apta a tratamento jurídico, fortemente marcada pela fides e que remontaria, provavelmente, ao séc. IV a.C. ${ }^{124}$ Dessa forma, o estudo da clientela pode ser tomado como paradigmático no âmbito da análise da fides no plano interno.

A clientela pode ser descrita como instituição correspondente a um tipo de estratificação social que tomava como pressuposto uma graduação entre o cidadão livre sui iuris e o liberto, implicando a existência de pessoas adstritas a determinados deveres de lealdade e obediência perante outras, em troca de proteção. ${ }^{125}$ Ademais, cabe observar que a relação de clientela era transmissivel e obrigava à ajuda recíproca. ${ }^{126}$

120. Cf. P. D. SENN. Buona fede cit. (nota 6l supra), p. 130.

121. Cf. A. M. R. Menezes CordeIRo. Da Boa-fé cit. (nota 5 supra), p. 59; P.D. SENN, Buona fede cit. (nola 61 supra). p. 131; G. Grosso, Buona fede cit. (nola 74 supra), p. 661; e D. NÖRr Die Fide cut (nota 67 supra), p. 18.

122. Cf. P. D. SENN, Buona fede cit. (nola 6I supra), p. 130. J. GAUDEMET, Fides cit. (nola 72 supra), p. 243, suscita, ainda, a hipótese de a fides ter, nas relações internas, eficácia no âmbito das obrigações, mais precisamentc do nexum. A. M. C. MENEzes CordeIro, Da Boa-fécit. (nota 5 supra), p. 63, por seu turno, refuta esta hipótese.

123. Cf. A. M. R. Menezes Cordeiro, Da Boa-fé cit. (nota 5 supra), p. 59-60; P. D. Senn, Buona fede cit. (nota 6I supra), p. 130; e P. VoCI. Manuale di diritto romano, $2^{3}$ ed, vol. II. Milano, Giuffrè, p. 267.

124. Cf. J. GAUDEMET, 'Fides' cit. (nola 72 supra). p. 243.

125. Cf. A. M. R. MENEzes CORdeiro. Da Boa-fé cil. (nola 5 supra). p. $59-60$.

126. Cf. F. SCHUlz. Prinzipien cit. (nota 68 supra), p. 201. 
Surge de forma clara na clientela uma situação de desigualdade jurídica, traduzida na inclusão do cliente (cliens) na família, sujeitando-se este ao pátrio poder. ${ }^{127} \mathrm{O}$ cliente passava a ser considerado o mais querido dos parentes, devendo ser defendido mesmo quando contra os consangüíneos, situação que revela de forma clara a firmeza com a qual a fides foi conservada na clientela. ${ }^{128}$

O cliente, conforme aponta F Schulz, era alcançado pelas obrigações de reverentia e obsequium, e a partir destas seria possível deduzir outras tantas obrigações patrimoniais e extrapatrimoniais. ${ }^{129}$

O patrono, de sua parte, não poderia testemunhar contra o seu cliente, tendo em vista que era titular do dever de defender este último, bem como o ajudar no que fosse preciso. ${ }^{130}$ Em verdade, nenhum outro delito era considerado tão grave quanto o de não prestar apoio ao cliente. ${ }^{131}$

Interessante notar que a presença da fides na clientela apresenta tanto aspectos domésticos quanto políticos. Sob este ponto de vista, cumpre rememorar a já aludida $^{132}$ vitória da plebe para substituir a fides dos patricios por uma fides mais vantajosa, através da promulgação da XII Tab. ${ }^{133}$

A determinação do conteúdo da fides na clientela não é tarefa simples. As opiniões em relação a esta questão são divergentes, conforme relata P D. SI:NiN: afirmação de autoridade, norma sacra que se põe com o objetivo de limitar a arbitrariedade do patrono, representação de um poder ou um limite a este e, talvez, uma virtude própria aos indivíduos que usam com moderação o seu próprio poder. ${ }^{134}$

Pode ser apontada a presença marcante de dois aspectos semânticos da referida noção: a fides como poder - identificada com a posição jurídica do patrão,

127. Cf. A. M. R. MEnezes Cordeiro, Da Boa-fé cit. (nolu 5 supra), p. 59-60.

128. Cf. M. Bretone. Storia cit. (nota 63 supra), p. 104.

129. Cf. Prinzipien cit. (nota 68 supra), p. 200.

130. Cf. F. SCHul7, Prinzipien cit. (nota 68 supra), p. 200-1. Quanto a esta fides do patrono nas relações de clientela, J. GAUDEMET, 'Fides cit. (nota 72 supra), p. 243, aponta que ela correspondia à expressão técnica in fidem esse (estar em fidess).

13I. Cf. M. BRETONE, Storia cit. (nula 63 supra), p. 104.

132. Cf. cap. IV.1.3 infra.

133. Cf. P. D. SENN, Buona fede cit. (nota 6/ supra), p. 130.

134. Cf. Buona fede cit. (nota 61 supra), p. 130. 
caracterizada, dentre outros, por poderes de direção - e a fides como manutenção da palavra dada, constatada na análise da ação pela qual um indivíduo era recebido na fides de outro, com raizes na anterior escravatura, advindo da possibilidade de aceder à situação de cliens na seqüência de alforria ou pela cupitis deminutio. ${ }^{135}$

Ainda que estes dois aspectos sejam os mais evidentes, não são eles os únicos elementos da fides a colorir as relações internas. Nesse sentido, aponte-se a lição de F. Amaral, para quem a fides, no âmbito das relações internas, concretizava o valor ético-religioso da antiga fides, como se constata na XII Tab. $(7,14)$, em que se estabelece a consecratio como sanção para a fraus do patrono para com o cliente. ${ }^{136}$

Conforme se nota, o prisma funcional da fides no plano interno compunha-se pelos três prismas semânticos desta noção, comprovando que lodos estes coexistiam e interagiam entre si.

De qualquer modo, a fides própria das relações internas foi incapaz de aportar limitações suficientemente caracterizadas como de Direito. Tratava-se apenas de uma dada estruturação social, à qual se vão associando representações religiosas e morais, configurando-se como um vínculo que implicava garantias de natureza não juridica. $^{137}$

\subsection{Fides no plano externo.}

Inicialmente, cumpre observar que no plano externo qual seja o das relações entre Roma c outros povos - o prisma funcional da fides tem contornos diversos e mais complexos daqueles presentes nas relações internas. ${ }^{138}$

O prisma funcional sob análise centrar-se-ia, especialmente, na deditio in fidem è na lealdade à palavra (tanto nos tratados internacionais quanto nos juramentos). Nesse passo, procederemos ao exame de ambas as situações.

135. Cf. A. M. R. Menezes Cordeiro, Da Boa-fé cit. (nota 5 supra), p. 60.

136. A Boa-fé cit. (nota 8 supra), p. 199.

137. Cf. A. M. R. MENEzes Cordeiro, Da Boa-fé cit. (nota 5 supra), p. 67.

138. Em relação a essa questão, observe-se que G. (iRosso, Buona fede cit. (nota 74 supra). p. 661 , apenas reconhecc uma clara diferenciação entre a fides das relações intemas e a das relações extemas após a época arcaica. apontando que nesta as relações intırnas, tendo origem em uma socicdade concentrada em grupos minoritários, apresentavam um notável paralelismo com as relações externas. 
Os romanos desenvolveram uma singular forma de capitulação, por meio da deditio in fidem. expressão prática da fides que pode ser descrita como um ato pacífico de confiança em um superior. A deditio estava intimamente relacionada com $o$ instituto da clientela. ${ }^{139}$ possivelmente tendo se originado na pacífica incorporação a esta. $^{140}$

Diferentemente da clientela entre cidadãos, este instituto estabelecia-se, conforme nota F. SCHULZ, entre uma comunidade e o homem de Estado que a tenha tomado sob a hegemonia romana. de modo que pode ser considerada uma forma de relação internacional entre Estados. ${ }^{141}$

Não obstante, também desta clientela internacional derivava uma série de deveres de proteção e lealdade do patrono (fides patroni), bem como uma relação de mútua dependência entre este e o cliente, de forma semelhante ao que ocorria no plano interno. $^{142}$

A deditio realizava-se mediante um acordo formal. celebrado em liberdade pelas partes, correspondendo a uma rendição pura e simples. A alteração de status é o fator verdadeiramente determinante: a população vencida perde sua capacidade jurídica segundo o ius gentium, incorporando-se à fides e ao domínio (dicio) romanos. ${ }^{143}$ Trata-se de ato totalmente dependente da boa vontade do vencedor. que põe o povo vencido em uma situação intermediária entre o aliado (socius) e o escravo. ${ }^{144}$

139. A clientela, como já se expôs no cap. IV.1.5, fundava-se em reciprocas relações de direitos e deveres entre o patrono e o cliente, baseadas na fides, estruturando o amplo campo das relações internas e externas de Roma.

140. Cf. D. NÖRR, Die Fide cit. (nota 67 supra), p. 25-36.

141. Prinzipien cit. (nota 68 supra), p. 201. No mesmo sentido, G. Grosso, Buona fede cit. (nola 74 supra), p. 661, baseado na análise de Cic. De off. I, 11.35.

142. Cf. D. NöRR, Die Fide cit. (nola 67 supra), p. 36

143. Cf. D. NÖRR, Die Fide cit. (nota 67 supra), p. 33. Discorda dessa opinião A. M. C. MENEZES CORDEIRo, Da Boa-fé cit. (nota 5 supra), p. 65, afirmando que a deditio implicava uma posição cm tudo semelhante à da conquista armada, pura e simples, e não um tratado, no sentido de pacto livremente celebrado. Como resultado, transpareciam conseqüências puramente negativas, notadamente a anulação da personalidade juridica do Estado vencido. Uma terceira opiniăo é apresentada por A. CARCATERRA, Intorno cit. (nola 66 supra), p. 197, o qual defende que no plano extemo a fides também não deve ser entendida como mero arbítrio ou poder, mas sim comn vínculo, mesmo em relação à deditio.

144. Cf. P. D. SENN, Buona fede cit. (nola 61 supra), p. 130. 
Os deveres gerados por esta fides não estavam expressamente formulados, sobretudo os referentes ao vencedor, e a relação de submissão (ordemobıdiência) ocupava o lugar das obrigações contratuais. ${ }^{145}$

Assim, a fides, em relação à deditio, simboliza a admissão do vencido, não somente no âmbito do domínio romano, mas também em seu ordenamento jurídico. Isto significa, acima de tudo, que as restrições de poder dos superiores, ao menus em princípio, aplicam-se também ao vencido. ${ }^{146}$

Quanto mais incompreensivel fosse a fórmula da deditio para os vencidos, conforme observa D. Nörr, maior deveria ser o terror destes ante o mágico binômio pergunta-resposta que ela apresentava. ${ }^{147}$

Podia ser a deditio seguida da receptio in fidem, pela qual o vencedor "renunciava" aos largos poderes conferidos pela deditio. A efetividade e a medida desta renúncia estavam, todavia, na disponibilidade de Roma, a quem cabia decidir acerca da matéria. $^{148}$

Com efeito, a única fonte vinculativa da fides residia no populus romumus, o qual, graciosamente, poderia se empenhar em renunciar ao uso da força e ao exercício dos direitos totais que adquiria sobre o vencido. se assim pensasse ser conveniente. $^{149}$ De fato, normalmente nenhum terceiro imparcial encarregava-se de precisar o conteúdo da fides; os romanos conservaram o poder de concreção, do qual se aproveitaram conscientemente. ${ }^{150}$

De qualquer forma, por meio da capitulação da deditio o vencido deixaria de pertencer a um âmbito externo, próprio dos inimigos, para passar a fazer parte de um âmbito normativo interno, protegido pela fides. ${ }^{151}$

Desse modo, guerra e paz, ódio e proteção, medo e confiança combinamse, de forma surpreendente, no referido ato. A brutalidade e a severidade do vencedor, a

145. Cf. D. Nörr, Die Fide cit. (nolu 67 supra), p. 33.

146. Cf. D. NÖRR, Die' Fide cil. (nota 67 supra), p. 37.

147. Cf. Die Fide cit. (nora 67 supra), p. 33. O autor cita relatos históricos acerca do assombro dos macedônios ante ao cerimonial romano.

148. Cf. A. M. R. Menezes Cordeiro, Da Boa-fé cit. (nola 5 supra). p. 65.

149. Cf. A. M. R. MENEZES CORDEiRO, Da Boa-fé cit. (nota 5 supra), p. 66.

150. Cr. D. NÖRR, Die Fide cil, (nota 67 supra), p. 17.

15I. Cf. D. NÖRR, Die Fide cit. (nota 67 supra), p. 36. 
partir duste momento, passam a ter um amplo campo de atuação, o qual não era. todavia, ilimitado. Em virtude da fides, o vencedor sujeitava-se a reivindicações das quais, de iure, não podia sc furtar. Frequientemente, por exemplo, o vencedor romano rechaçava a aceitação da fides da deditio quando queria proceder livremenle contra os vencidos, mediante matança ou escravização. Daí deduz-se a norma "mínima" da deditio: a proteção da vida e da liberdade. ${ }^{152}$

Nesse diapasão, conforme aponta G. Girosso, a fide's estava particularmente viva e operante nos confrontos dos estrangeiros, cuja posição e relação com os Romanos determinava-se e desenvolvia-se, precisamente, sob a égide de tal noção. Esta rulação assumiria, assim, uma expressão imperialista ${ }^{153}$ colocando a fides como verdadeiro fator de submissão a Roma. ${ }^{154}$

O culto à deusa Fides teria servido para que os romanos pusessem nas mãos dos mais fracos, mediante o elogio de sua fides, um instrumento de influência em seu próprio comportamento. 155

Confirmando essa expressão imperialista, A. M. R. Menezes Cordeiro observa que a evolução da fides nas relações externas justamente corporizou sob forma juridica a agressiva expansão romana. em detrimento dos outros povos. ${ }^{156}$

Todavia, interessante notar que a fides populi Romani, de forma parodoxal, não serviu apenas como vetor imperialista romano, verdadeiro fator de domínio e submissão. Esta fides pública foi também louvada como virtude, vista como garantia de lealdade e de respeito a alguns princípios de correção e confiança. ${ }^{157}$

152 C'f. D. NörR, Die Fide cit. (nola 67 supra), p. 36.

153. Cf. Buona fede cit. (nota 74 supra). p. 661.

154. Cf. Francisco Amaral, A Bou-fé cit. (nola 8 supra). p. 199.

155. Apenas quando se considera a brutalidade do antigo Direito de guerra (ius belli) - o qual não protegia verdadeiramente os vencidos, facultando aos vencedores tomar medídas como o assassinato e a escravização dos primeiros - é que se pode compreender a eficácia da fides romana como pauta de comportamento. Cf. D. NürR, Die Fide cil. (nota $6^{7}$ supra), p. 17; 24.

156. Este vetor ficou claro no Tratado Romanu-Etólico de 212 - ou 211 aC.Cf. Da Boa-fé cit. (nota 5 supra), p. 64.

157. Cf. G. Grosso, Buona fede cit. (nora 74 supra), p. 661. Nesse sentido, cite-x também a lição de FRANCISCO AMARAL, A Boa-fé cit. (nota 8 supra), p. 199, para quem nas relações intemacionais a fides era "vista como virtude, garantia de lealdade e respeito, de correçào e de confiança" 
Os romanos, sobretudo no âmbito das relações internacionais, gabavamse de ser o povo da fides, e orgulhosamente a contrapunham às noções semelhantes dos cartagineses e dos gregos. ${ }^{158}$

Em verdade, a inobservância da fides, na visão do povo romano, seria uma mazela social. Observar a fides seria um dos princípios da vida, aquilo que nesta há de mais santo, base de toda a felicidade humana. ${ }^{159}$

Alguns exemplos históricos, conforme nota D. Nörr. denunciariam que a fides por vezes chegava a ser uma noção hipócrita, usado pelos romanos para mascarar suas ações. ${ }^{160}$ De modo geral, contudo, teria havido entre os diversos povos estrangeiros um amplo consenso accrca do fato de que os romanos, em geral, poderiam com razão orgulhar-se da sua fides. ${ }^{161}$

A par das relações de domínio impostas a povos estrangeiros, conforme observa A. M. (. Menezes Cordeiro, nota-se uma fides caracteristica das relações externas, base dos convênios livremente assumidos. ${ }^{162}$

Essa fides apresentava fortes traços do aspecto da lealdade à palavra, estando presente em situações diversas como a celebração de pactos de proteção mútua e o cumprimento de tratados internacionais. A este propósito, alguns exemplos históricos merecem ser apontados, uma vez que são dotados de papel representativo da mentalidade romana e do papel da fides.

Um primeiro testemunho da fides ora examinada foi o tratado celebrado entre Roma e Cartago, no auge da Primeira Guerra Púnica. Neste documento, estipulou-se que os cidadãos de cada uma das partes gozariam. na Sicília. de proteção nos negócios no setor de influência da outra parte, sendo esta proteção assegurada pela

158. Cf. F. S('HUL\%, Prinzipien cit. (nota 68 supra), p. 193. D. NÖRR, Die Fide cit. (nota67 supra), p. 17, comprova essa relação de orgulho ao reproduz as palavras de Valerio Maximo (contemporâneo do imperador Tibério): "(...) venerubile Fidei numen dexteram suam, cerlissimum salutis humanae pignus, ostental, quam semper in nostra civitate viguisse et omnes gentes senserunt (...)" (A venerável deusa Fides levanta a sua mão direita como símbolo certissimo da segurança humana. que sempre se manteve em nossa cidade, assim como foi reconhecida por todas as demais nações).

159. Cf. F. SCHULz, Prinzipien cit. (nota 68 supra), p. 193-194.

160. Nesse sentido, claras são as palavras do rei sirio Hierão II ao afirmar sarcasticamente, em 264 a.C., que a todo tempo brotava a fides dos lábios dos romanos, mas em rcalidade apenas para conseguir alcançar seus interesses egoistas. Cf. Die Fide cit. (nola 67 supra), p. 17.

161. Cf. D. NURR, Die Fide cit. (nota 67 supra), p. 17.

162. Cf. Da Boa-fé cit. (nola 5 supra), p. 68. 
fides. Aplicada nesse contexto, a fides externa revestira, na Roma do séc. III a.C., a natureza de ponto de referência vinculante em pactos igualitários, compreendendo a obrigação e a garantia estatal da força vinculante do ato. ${ }^{163}$

Um segundo exemplo, descrito por Cícero é o do cônsul romano Marco Atílio Régulo, aprisionado pelos cartagineses durante a já referida Primcira Guerra Púnica, ${ }^{164}$ e enviado a Roma com a missão de trocar prisioneiros e mediar um acordo de paz. Antes de sua partida, o cônsul teve de prestar juramento obrigando-se a regressar a Cartago na eventualidade de frustarem-se os objetivos de sua missão. ${ }^{165}$

Quando chegou a Roma, o cônsul não se deixou seduzir pelas vantagens da conveniência de frustrar o juramento (ficar em Roma, em sua casa, ao lado da esposa e dos filhos, retendo sua patente e dignidade de ex-cônsul); demonstrando invejáveis coragem e virtude. compareceu ao Senado e anunciou sua missão. recusando-se a votar no exame da questão, tendo em vista que. enquanto vinculado aos inimigos por juramento. ele não mais era um membro senatorial. Ao ser indagado sobre sua opinião. Régulo afirmou que a libertação dos prisioneiros de guerra seria inoportuna, uma vez que estes eram jovens e galantes oficiais. ao passo que ele já era idoso. Quando o conselho de Régulo prevaleceu, os prisioneiros permaneceram retidos e ele, fiel a seu juramento, retornou a Cartago, onde morreu martirizado. ${ }^{166}$

Para Cícero. a afeição do cônsul em relação à família e à pátria, bem como a consciência de um destino marcado por torturas nas mãos de um dos mais cruéis inimigos de Roma, não foram suficientes para impedi-lo de manter o juramento prestado aos cartagineses. Régulo teria encarado o destino de sofrimento e tortura para manter-se fiel a seu dever moral. pois acreditava ser moralmente correto expor sua convicção (de que seria danosa a libertação dos prisioneiros), e por ela sofrer. ${ }^{167}$

163. Cf. A. M. R. MEnEzes Cordeiro, Da Boa-fé cit. (nota 5 supra), p. 64: e G. Grosso, Buona fede cit. (nola 74 supra). p. 662.

164. Mais precisamente, em 255 a.C. na batalha de Túnis, África, pelo estratagema de Xântipo Lacedemônio, um general espartano servindo sob o comando de Hamilcar. As datas precisas são indicadas pelo tradutor da obra de (ícero, tendo em vista que o orador romano desprizou a indicação de tais detalhes. Cf. CiCERo. De officiis, trad. ing. de Walter Miller, Cicero-On Duties. Cambridge. Harvard University, 1913, p. 374.

165. Cf. De off. 3, 26, 99; 3, 27, 100.

166. Cf. Cic. De off. 3, 26, 99; 3, 27, 100. Novamente, as datas precisas são indicadas pelo tradutor. consoante explanado na nota 165 supra.

167. (f. De off. 3. 29. 105:3, 30, 110. 
Partinclo deste exemplo. Cícero observa que ao prestar-se um juramento há um dever de considerar não o que se pode temer em caso de violação, mas em quê reside a obrigação. Um juramento seria uma certificação lastreada por santidade religiosa; assim, a prestação de uma promessa solene, ante Deus como testemunha. deve ser sagradamente mantida. Isto porque a questão não mais diz respeito à ira dos deuses (lendo em vista que esta não existe) mas às obrigações de iustitia e fides. Dessa forma, quem viola um juramento prestado estaria violando a deusa Fides. ${ }^{168}$

Ainda, quando um tratado internacional continha expressas obrigações de apoio militar, Roma obrigava-se, em sentido estrito, a seu cumprimento. Os romanos evitaram, quando possível, limitar a própria liberdade de atuação mediante tal espécie de cláusula. com promessas de ajuda em determinadas situações. Muito pelo contrário. sem necessidade de cláusula alguma, sentiram-se legitimados e, dentro de um âmbito discricionário, obrigados, em virtude da fides, a intervir militarmente em relação a seus amigos e aliados (amici iet socii) ${ }^{169}$

Assim, a fides deixava de ser mera lealdade ao acordado para converterse em um modo geral de comportamento, o que teria motivado Cícero a afirmar que o povo romano conseguira dominar todas as terras defendendo os povos aliados (noster autem populus sociis defendendis terrarum iam omnium potitus est $)^{170}$

Para D. Nörr, é inquestionável que a agressão a um amicus et socius populi Romani colocava em discussão a fides romana. Como exemplo, cita a conquista de Sagunto por Aníbal. Sagunto. em que pese o fato de não ter acordo internacional celebrado com Roma, havia se submetido à proteção desta, mediante pacífica deditio in fidem, motivo pelo qual havia alcançado o status de amicus et socius. A fides exigiu uma reação contra Aníbal, considerado por Roma como agressor ${ }^{171}$

168. Em relação a esse tuma, o pensador romano cita um trecho de Ênio: "Ó Fides alma apta pinuis ét ius iurandum lovis" (Graciosa Fides, elevada em asas, jures sob o grande nome de Júpiter). Cf. De off. 3, $29,104$.

169. Cf. D. NÖ́R, Die Fide cit. (nota 67 supra), p. 20.

170. C.f. D. NÖRR, Die Fide cit. (nola 67 supra), p. 20.

171. Cf. Die Fide cit. (nota 67 supra). p. 22-23. A obrigação de reparar a injustiça cometida em Sagunto pode, inclusive, ser considerada um das causas que levaram Roma à Segunda Guerra Púnica, a qual acabou por conceder-lhe o domínio sobre o Mediterrâneo ocidental. Cf. D. NörR, Die Fide cùl. (nota 67 supra), p. 23. Ressaltando a relevância das relações de aliança, F. SCHULZ, Prinzipien cit. (nota 68 supra). p. 204, afirma que para os romanos os amigos (aliados) eram considerados mais necessários do que o fogo, a água e o pão. 
Outro exemplo que deve ser citado é o controverso "caso Mancino"172. o qual, segundo D. Nörr, demonstra a minuciosa observância da fides como lealdade ao acordo, bem como a hábil superação dos problemas derivados do cumprimento da fides $^{173}$

Após desafortunadas lutas com os numantinos, o cônsul Hostílio Mancino celebrou, em 137 a.C., um acordo de paz, provavelmente na forma de sponsio. Este acordo teria sido desaprovado pelo povo e Senado romanos, o que the trouxe um problema de eficácia jurídica. Por um lado, o acordo fora celebrado sem o consentimento do povo romano, de modo que sua eficácia vinculante com respeito ao povo era mais do que duvidosa. De outra parte. o magistrado havia comprometido a fides publica. Ademais, a permanência em Roma de um magistrado que não havia cumprido um tratado era considerada ofensa grave ${ }^{174}$

Para concomitantemente satisfazer as exigências da fides e suspender o cumprimento do tratado, aprovou-se uma lei, por sugestão de Mancino, de entrega solene de seu corpo aos numantinos. E assim foi feito: o pater patratus ${ }^{175}$ ofereceu, com palavras solenes, o corpo desnudo e atado do cônsul, o que foi recusado pelos numantinos. ${ }^{176}$

Ao final, Mancino foi reposto, por lei, em seus direitos civis, e a interpretação jurídica oficial romana foi a de que, com a intenção da entrega solene do general que havia celebrado o tratado, Roma liberava-se do cumprimento deste. Por meio de tal solução, a fides como lealdade ao acordado havia sido respeitada e permanecido praticável. ${ }^{177}$

Episódio semelhante seria o da celebração da paz entre Roma e os Samnitas. Os generais Tito Vetúrio e Espúrio Postúmío perderam a batalha de Cáudio,

172. Cr. Cic. De off. 3, 30, 109; 3, 30, 110.

173. Cf. Die Fide cit. (nota 67 supra), p. 19.

174. Cf. D. NÖRr. Die Fide cit. (nota 67 supra). p. 19-20.

175. Esse pater era o membro do colégio sacerdotal com competência para assuntos internacionais. Cf. D. NÖR. Die Fide cil. (nota 67 supra). p. 19.

176. Cf. D. NÖRR, Die Fide cil. (nola 67 supra), p. 19-20.

177. Ainda assim, tratava-se de um caso excepcional de resolução contratual salva fidc: a regra era a lealdade ao acordado, entendido em sentido positivo. A frustada entrega solene pode ser considerada mais como um sacrificio por um povo do que como a punição de um infrator du Direito, como comprova a estátua de Mancino desnudo erigida em Roma. Cf. D. NÖRR, Die Fide cil. (nola 67 supra). p. 19-20. 
e celebraram a paz sem o consentimento do Senado e do povo. Os generais, assim como os tribunos do povo Tibério Numício e Quinto Mćlio (os quais sancionaram a conclusão do acordo de paz), foram entregues aos inimigos, de modo a permitir que o acordo de paz fosse anulado. Curiosamente, esta atitude foi proposta e defendida pelo próprio Postúmio. ${ }^{178}$

Em ambos os exemplos históricos, a retidão moral teria prevalecido sobre a conveniência. Já $\mathrm{cm}$ um terceiro caso, o protagonista teria se rendido aos falsos atrativos da conveniência, sacrificando a retidão moral: Quinto Pompéio, vivenciando situação idêntica à de Mancino, advogou contra a medida, proposta ao Senado, que almejava determinar sua entrega ao inimigo. ${ }^{179}$

Como sintese dos eventos históricos apontados, releva reproduzir a seguinte citação de Cícero: "os romanos têm leis para regular as guerras, $e$ a fidelidade a um juramento deve freqüentemente ser observada em negociações com o inimigo. Um juramento prestado com a clara consciência de que é necessário seu cumprimento deve ser mantido" 180

O mérito dos exemplos históricos apontados, segundo Cícero, reside na época destes, e não nos homens que os protagonizaram. Isto porque os romanos antigos acreditavam que nenhum vínculo era mais eficiente para garantir a fides do que um juramento. Esta afirmação poderia ser comprovada pela XII Tab., pelas leis sacras, pelos tratados nos quais a fides era garantida até aos inimigos e pelas penalidadesinvestigações feitas pelos censores e penalidades por eles impostas. ${ }^{\mid 81}$

Observa-se, portanto, que para os romanos a fides deveria sempre ser preservada fírme nas relações públicas, quaisquer que fossem as vicissitudes. Assim, mesmo quando se estivesse guerreando com um inimigo legítimo e declarado, os juramentos a este prestados deveriam ser mantidos, como se fossem tratados mútuos.

178. Cf. Cic. De off. 3, 30, 109; 3, 30, 110.

179. Cf. Cic. De off. 3, 30, 109; 3, 30, 110.

180. Cf. Cic. De off. 3, 29, 107.

181. Cf. Cic. De off. 3, 31, I11, "Nullum enim vinculum ad astringendam fidem iure iurando maiores artius esse voluerunt. Id indicant leges in duodocim tabulis, indicant sacratae, indicant foedera, quibus etiam um hoste devincitur fides, indicant notiones animadversionesque censorum, qui nulla de re diligentius quam de iure iurando iudicabant". 
Não fosse isso verdade, Roma não teria entregue acorrentados aos inimigos os cônsules, os quais eram os homens mais ilustres à época. ${ }^{182}$

\subsection{Fides e objetivização do comportamento.}

Com base no exposto, parece inevitável deduzir-se que a fides teve um papel notável na antigüidade, especialmente em Roma, apresentando-se ativamente operante e dominante nas relações internacionais - seja entre Estados, seja entre cidadãos de Estados diversos - bem como profundamente enraizada nas relações privadas. $^{183}$

A fides nasceu no seio das civilizações clássicas como regra de responsabilidade voltada a conferir objetividade aos comportamentos dos indivíduos, de modo a permitir maior grau de previsibilidade e segurança nas relações humanas.

Como observa P Frezza, a autoconsciência, que revela o homem a si mesmo, mostra-lhe também a existência do ser alheio, consciente ele próprio; no encontro destes dois seres, confrontam-se suas consciências. Neste contexto, a experiência do diálogo -.. contato imediato entre dois sujeitos - dá margem ao fenômeno da compreensão, a qual, todavia, não pode pressupor a identidade entre as partes, tampouco a absoluta diferenciação. ${ }^{184}$

O fenômeno da compreensão abrange, portanto, o paradoxo de oferecer ao outro - e dele esperar em troca - um "si próprio" (alter ego) que não frustre a expectativa de continuidade, de não contrariedade do comportamento esperado. Este paradoxo da autenticidade do sujeito humano, superposto ao fenômeno da compreensão, passou a ser traduzido pela noção de fides. ${ }^{185}$

Assim, a fides consistiria em uma tentativa de objetivação do comportamento humano, de modo a possibilitar a previsibilidade das condutas

182. Cf. M. BRETONE, Storia cit. (nota 63 supra), p. 104.

183. Cf. G. Grosso, Buona fede cit. (nota 74 supra), p. 661.

184. Cf. A proposito di 'fides' $e$ bona fides' come valore normativo in Roma nei raporti dell'ordinamento interno e internazionale in SDHI 57 (1991), p. 299.

185. Cf. P. FrtzZA, A proposilo cit. (nola 185 supra), p. 300 . Conforme revela o autor, essa constatação teria levado o estóico Epiteto a proceder à identificação entre a fides e a própria nanureza do homem: "o homem nasceu para a fides e, aquilo que a subverte, subverte a propria natureza humana" 
individuais no âmbito de relações interpessoais, procurando adequar tais condutas aos padrões esperados de um homem médio comum (bonus paterfamilias).

Inicialmente, a objetivação do comportamento era voltada aos contatos mantidos entre o homem e a divindidade. passando posteriormente a abranger relações bipolares que implicavam a assunção de vínculos.

Em ambas as situações, a objetivação do comportamento humano pressuporia a necessidade de manutenção da palavra dada, bem como o respeito às garantias advindas de vínculos de poder, e implicaria a necessidade de adequação às condutas previstas em normas, jurídicas ou não.

\subsection{Natureza.}

Após examinados os principais aspectos da fides, cumpre analisar a natureza desta, especificamente no que concerne à possibilidade de tal noção ser compreendida como verdadeira norma jurídica. Esta análise revela-se fundamental para que, posteriormente, possa-se estudar a passagem da fides àfides bona.

Em relação à vexata quaestio em tela, pode-se a apontar que a doutrina romanística tende a concentrar seus entendimentos em duas correntes distintas, a saber: (i) a fides seria uma norma jurídica; (ii) a fides não portava conseqüências jurídicas, sendo apenas uma noção ética e moral.

A parcela majoritária dos romanistas defende que a fides deve ser compreendida como uma norma jurídica, ${ }^{186}$ compreendida como principio jurídico, convenientemente desenvolvido desde os tempos antigos, ${ }^{187}$ fundamento de obrigatoriedade jurídica para todos os homens sem distinção da sua nacionalidade. ${ }^{188}$

186. P. Bonfante, Essenza cit. (nota 6 supra), p .719; J. C. MOREIRA Alves, Direito Romamo. 13. ed., v. II, Rio de Janeiro, Forense, p. 313; P FrEZZA, A proposito cit. (nota 185 supra), p. 300 ; M. KASER, Das römisches cit. (nota 61 supra), p. 50; F. SCHUlz, Prinzipien cit. (nota 68 supra), p. 194 s; P. VOCI, Manuale cit. (nota 124 supra), p. 267; e FRANCISCO AMARAL, A Boa-fécit. (nota 8supra), p. 202.

187. Cf. P. VoCI, Manuale cit. (nota 124 supra), p. 267; e F. SCHULL, Prizipien cit. (nota 68 supra), p. 194 ss.

188. Cf. M. KASF.R, Das römisches cit. (nola 61 supra), p. 50. 
Reconhecida a natureza da fides como norma juridica. ter-se-iam como conseqüincias diretas o reconhecimento do estreito vínculo que nasce de um contrato obrigatório válido e do negócio jurídico não solene. ${ }^{189}$

Já a segunda corrente. sustentada sobretudo por A.M.C. Menezes Cordeiro, J. Paricio e P. D. Senn, rejeita todas as orientações que da fides pretendam retirar conseqüências jurídicas que não as extraídas em um momento posterior do Direito Romano, mas então já com a adjunção de bona. Para estes autores, a fídes não estava um condições de, por si, trazer uma força vinculativa. Tratar-se-ia, na verdade, de uma noção cujo conteúdo seria de natureza ética e moral, e não jurídica. ${ }^{190}$

Posição intermediária a estas duas teses é capitaneada por D. Nörr, ao defender que a fides aplicável à relações externas de Roma tinha a natureza de norma jurídica, o que restaria comprovado pelo fato de que, uma vez violada, habitualmente era punida ou, ao menos ameaçada, com sanções. ${ }^{191}$

Esta corrente reconhece que a apelação à fides não deve ser interpretada como uma mera apelação a excelsas qualidades virtuosas, como a compaixão, a clemência e a benevolência, mas sim como norma jurídica. ${ }^{192}$

A singularidade desta natureza juridica, todavia, seria difícil do precisar ${ }^{193}$ Ao que tudo indica, a tutela concedida pelo ius gentium às relações com peregrinos teria levado ao ingresso da fides no ordenamento jurídico romano, e a transformação desta, de norma-basc, autônoma, em objeto (de disciplina e tutela) da parte de uma norma do ordenamento positivo. ${ }^{194}$

Comprovaria essa asserção o fato de que, já no início da República romana, a fides teria sido crigida à condição de norma juridica destinada a garantir a

189. Cf. F. SCHULL. Prinzipien cit. (nota 68 supra). p. 194.

190. Cf. Da Boa-fé cit. (nota 5 supra), p. 70; Buona fede cit. (nota 61 supra), p. 131. No mesmo sentido, J. PARJClo, Historia cil. (nota 65 supra), p. 98;

191. Cf. Die Fide cit. (nota 67 supra), p. 16-17. No mesmo sentido, A. CARCATERra, linomo cit. (nola 66 supra), p. 167. Em relação ao referido tema, M. G. ZOZ, Il nwolo della buona fede nel contratto di transporto maritimo in II ruolo della buona fede oggetiva nell esperienza giuridica storica $e^{\prime}$ contemporanea, vol. IV, I.uigi Garofalo, Padova, CEDAM, 2003, p. 541, nota que a fides possibilitou sancionar, primeiro não juridicamente c depois juridicamente, as relações juridicas mantidas entre romanos e estrangeiros, trazendo adequação do Direito às novas necessidades econômicas.

192. Cf. D. NörR, Die Fide cil. (nota 67 supra), p. 37.

193. Cf. D. NÖRR, Die Fide cit. (nota 67 supra), p. 17.

194. Cf. A. CARCATERRa, Intorno cil. (nota 66 supra), p. 197. 
proteção jurídica dos contratos de compra e venda que haviam sido celebrados conforme as cláusulas do Primeiro Acordo Romano-Cartaginês. ${ }^{195}$

Com base no estudo comparativo destas diferentes correntes, parece lícito defender a natureza de norma jurídica para a fides apenas no que concerne ao prisma funcional que esta apresentava nas relações externas de Roma. Fundamentam esta asserção as importantes conseqüências jurídicas trazidas por esta noção no plano internacional, como a necessidade de observância dos vínculos contraídos e as sanções previstas para a sua violação.

Em que pese ser admissível essa natureza jurídica da fides no plano externo, não parece cabível afirmar que se possa falar em uma norma geral de fides no Direito Romano, muito menos em uma prematura representação de um princípio de boa-fé romano. ${ }^{196}$

Mais assentado parece ser defender que a fides, em lugar de fonte jurígena, configuraria uma "medida" tendo em vista que não se imporia por si, mas por elementos de Direito positivo material e processual. ${ }^{197}$ Com efeito, consoante intentaremos demonstrar abaixo, ${ }^{198}$ os ideais da fides encontram vinculação jurídica a partir do momento em que passam ser assegurados pela bona fides - esta sim verdadeira norma jurídica e pela tutela dos bonae fidei iudicia.

De qualquer modo, a fides seria uma das categorias essenciais para a compreensão do ordenamento jurídico romano, uma vez que representaria a expectativa de comportamento conforme a norma, seja esta ética, moral ou jurídica. ${ }^{199}$

Mais do que isso, consoante procuraremos demonstrar, a fides seria a base da fides bona, princípio jurídico que somente em um momento posterior seria introduzido no Direito Romano, por obra dos pretores. ${ }^{200}$

De fato, não obstante essa evolução conturbada e imprecisa da fides, com falta de precisão nas utilizações jurídicas, ainda incipientes, tal noção conservaria uma

195. Cf. D. NÖRR, Die Fide cit. (nota 67 supra), p. 17.

196. Cf. D. NöRr, Die Fide cit. (nora 67 supra), p. 37. Em sentido contrário, P. VoC, Momaale cit (nola 124 supra), p. 267.

197. Cf. A. CAR('ATERRA, Ancora sulla 'fides 'e sui 'bonae fidei iudicia' in SDHI33(1967), p. 66. 198. Cf. cap. IV.2.

199. Cf. D. NÖRR, Die Fide cit. (nota 67 supra), p. 16.

200. Cf. cap. IV.2.4. 
conotação séria e profundamente enraizada no imaginário da coletividade romana, suscetível de provocar reações afetivas nas pessoas. Desse modo, a fides estava especialmente vocacionada e disponível para dar cobcrtura a novidades juridicas, dentre as quais se destacou a fides bona. ${ }^{201}$

2. Da fides à bona fides.

2.1. Considerações iniciais.

Consoante se expôs acima, não parecc caber à fides um papel verdadeiramente jurígeno, muito menos de norma de boa-fé romana, posição esta que. conforme se procurará demonstrar, apenas pode ser imputada à fides hona (ou bona fides).

Verdadeira vexara quaestio, a transição da fides às noções defides bona e bona fides tem agitado a doutrina histórico-jurídica, sem que se possa falar em soluções definitivas. $^{202}$ Para que se possa analisar este debate, contudo, faz-se necessário que se apresentem algumas considerações preliminares acerca das noções de hona fides e fides bona

2.2. Contornos gerais da hona fides.

Inicialmente, deve-se observar que a communis opinio refere-se de forma indiscriminada à boa-fé romana como bona fides ou fides bona. assumindo tais noções como equivalentes. 203

201. Cf. A. M. R. Menezes Cordeiro, Da Boa-fé cit. (nota supra), p. 69

202. Cf. A. M. R. Menezes Cordeiro, Da Boa-fé cil. (nota 5 supra), p. 71.

203. Os seguintes autores não apontam uma possivel distinção entre bona fides e fides bona: A. S. Justo, Direito Privado Romano, vol. III, Coimbra, Coimbra, 2000, p. 87; M. TAlAmanCA, La "bona fides 'cit. (nota 10 supra), p. I ss; F. SCHULz. Prinzipien cit. (nota 68 supra), p. 198; J.PARICIO, Historia cit. (nola 65 supra), p. 97; M. BRETONE, Storia cit. (nota 63 supra), p. 104; P. BONFANTE, Essereu cit. (nota o supra), p. 718-719; G. GRosso, Buona fede cit. (nota 74 supra), p. 643. Quanto à parcela doutrinária que procede à referida diferenciação, cf. cap.IV.2.3 infra. 
A bona fides, que não econtra definição alguma nas fontes, ${ }^{204}$ caracterizar-se-ia como uma noção jurídica ${ }^{205}$ que atuava como verdadeiro critério de valoração das circunstâncias do caso concreto. ${ }^{206}$

Fissa noção juridica imporia às partes de um negócio concreto uma série de deveres que deviam ser cumpridos na relação juridica, implicando o respeito aos próprios vínculos e promessas assumidos, observando-se o padrão de comportamento correspondente aos costumes de confiança, honestidade, correção e lealdade das pessoas de bem. ${ }^{207}$

Tratar-se-ia, portanto, do dever genérico de comportar-se com retidão nas relações jurídicas, que poderia ser reportado aos ideais da fides, notadamente em relação ao respeito à palavra dada, com o qual mantinha uma concxão bastante cstreita. Dessa forma, possibilitava-se a prevalência de simples acordos sobre outros valores, essencialmente formais. ${ }^{208}$

Sob esse ângulo, resulta significativo um aspecto que sempre acompanhou a operatividade da bona fídes, qual seja o seu caráter unicamente setorial. Apenas para determinadas relações jurídicas típicas era possível empregar o esquema normativo da bona fides, sendo para tanto necessária a tutela processual formular baseada no oportet ex fide bona. ${ }^{20 y}$

Conforme nota $P$. Bonfante, resta claro que nas diversas relações juridicas o comportamento de lisura e lealdade, compreendido na bona fides. deve se referir a um objeto determinado e diverso. O dever abstrato e geral de conduta conforme o homem médio deve, em cada relação, explicar-se em algum dever concreto e particular. 210

204. Cf. M. TALAMANCA, la 'bona fides' cil. (nola 10 supra), p. 30.

205. A noçào de bona fides, para P. D. SENN, Buona fede cit. (nota 61 supra), p. 130, seria tipicamente técnico-juridica, uma vez que não poderia ser encontrada nos textus literários.

206. Cf. Francisco Amaral, A Boa-fé cit. (nota 8 supra), p. 197.

207. Cf. F. SCHUlZ, Prinzipien cit. (nola 68 supra), p. 198 ; J. PARIClO, Historia cit. (nota 65 supra), p. 97: M. BRETONE. Storia cit. (nota 63 supra), p. 104; e FranCisCo AMARAL, A Boa-fé cit. (nota 8 supra). p. 200.

208. Cf. M. TAlamanCA. La 'bona fides' cil. (nota 10 supra), p. 46.

209. Cf. M. TalamanCA, La bona fides cil. (nota 10 supra). p. 40: 47.

210. Cf. Essenza cit. (nola 6 supra), p. 718-719. 
A noção do que deve ser compreendido como bonu fides $\mathrm{cm}$ cada situação seria mesurada em relação às particularidades e expectativas da sociedade. e remetida em sua extensão à apreciação do juiz, o qual teria por tarefa interpretar tal noção e aplicá-la ao caso concreto. ${ }^{211}$ Este critério supraindividual e objetivo constuma ser definido como a fides do bonus vir. ${ }^{212}$

Dessa forma, a bona fides pode ser compreendida como um principio normativo de justiça contratual, que visaria a tutelar o equilibrio contratual, garantindo a igualdade das posições dos contraentes. por meio da atuação judicial. Tratar-se-ia de um critério do grau de tolerabilidade da estrutura do equilíbrio da prestação como vontade das partes, um vetor de integração necessário ao conteúdo do contrato. ${ }^{213}$

Nesse contexto, a bona fides caracterizar-se-ia como um dos fundamentos materiais e constitutivamente decisivos do Direito romano, no qual o casuísmo tópico-jurisprudencial atuava analogicamente, por referência a valores fundamentais. ${ }^{214}$

A bona fides era, em sintese, um critério normativo de comportamento. que modelou todo um complexo de relações obrigacionais romanas, fornecendo a possibilidade de valorá-las objetivamente, por mcio da atuação judicial. ${ }^{215}$

Por fim, note-se que a presente noção de bona fides distingue-se daquela aplicável na seara dos Direitos Reais, a qual se identifica com a noção de boa-fé subjetiva adotada nos ordenamentos jurídicos contemporâneos. ${ }^{216}$

Essa bona fides em sentido subjetivo, conforme se intenterá demonstrar abaixo, ${ }^{217}$ foi o resultado de um processo de difusão, tanto horizontal quanto vertical, sofrido pela noção de hona fides em seu sentido original.

211. Cf. P. BONF A vTE. Essenza cit. (nota 6 supra), p. 718.

212. Cr. J. PARIC 'IO, Historia cit. (nota 65 supra), p. 97; e P. D. SENN, Buona fede cit. (nota 61 supra), p. $|3|$.

213. Cf. R. CARDILLI, La buona fede come principio di diritlo dei contrati. in Roma c'America Dirilto romano comune 13 (2002), p. 185.

214. Cf. Francisco Amaral, A Boa-fé cit. (nota 8 supra), p. 198.

215. Cf. G. Grosso, Buona fede cit. (nola 74 supra). p. 643.

216. Cf. J. PARICIO, Historia cit. (nota 65 supra), p. 98; P. D. SENN, Buonafede cit. (nota 61 supra), p. 131; e M. TALAMANCA, la 'bona fides' cit. (nota 10 supra), p. 10.

217. Cf. cap. IV.5. 
2.3. Fides bona e bona fides.

Uma segunda orientação doutrinária procura distinguir as noções de bona fides e fides bona, alegando que haveria uma pretensa diferença filológica e funcional entre ambas. ${ }^{218}$

Para os defensores desta corrente, a antítese própria das relações reais e das obrigacionais encontraria pólos na oscilação existente entre a bona fides, subjetiva (como erro ¿ ignorância), e a fides bona (como critério normativo), objetiva. ${ }^{219}$

Lm verdade. parece correto afirmar que fides bona e bona fides seriam expressões equivalentes, que portariam a mesma significação. Corroboraria este argumento o fato de que a pretensa diferenciação defendida por uma parcela minoritária da doutrina romanística. como visto acima, não é acompanhada por comprovações nas fontes. Ademais, deve-se ter em consideração a estrutura da língua latina, na qual o sistema de flexões de casos permite que a ordem das palavras seja alterada sem que isso implique mudança semântica nas sentenças; ${ }^{220}$ assim, seria natural haver referências tanto à expressão fides bona quanto à bona fides, uma vez que os termos bona e fides estão igualmente flexionados em ambas. ${ }^{221}$

A expressão fides bona encontra-se, sobretudo, utilizada no âmbito dos bonae fidei iudicia, como cláusula formular (oportet ex fide bona), critério segundo o qual o juiz deve julgar a relação juridica concreta. Já a expressão bona fides, por scu turno, parece ser usada para retratar a noção substancial de boa-fé. ${ }^{222}$ Ambas, contudo, referir-se-iam ao aspecto objetivo da boa-fé, apresentando identidade semântica.

218. Cf. A. M. R. MENezes CORdeIRO, Da Boa-fé cit. (nota 5 supra), p. 71; FranciscoAMARAL, A Boa-fé cit. (nola 8 supra), p. 200; e G. PUGLIESE. Istituzioni di diritto romano, 22 ed, Torino. Giapp ichelli. 1990, p. 507.

219. Cf. Francisco Amaral, A Boa-fé cit. (nota 8 supra), p. 200.

220. De fato. em latim uma mesma palavra tem terminaçòes distintas para indicar a função que exerce na oração (flexão de caso). Cf. NAPOLEÃo MENDES DE AL.MEIDA. Gramática Latina, 29" ed, São Paulo, Saraiva, 2000, p. 14-15.

221. Assim, parece assentado afirmar a possibilidade de usar o termo bona fides tanto em sentido objetivo como subjetivo. Cf. M. TALAMANCA, La 'bona fides' cit. (nola 10 supra), p. $13 \mathrm{ss}$.

222. Não obstante, é raro o emprego da expressão bona fides em provimentos normativos que não o edito do pretor. Cf. M. TALAMANCA, La 'bona fides' cit. (nota 10 supra), p. 16. 
Todavia, tendo em vista o fato de que a bona fides posteriormente sofreu diluição, e passou a significar também "boa-fé subjetiva" ${ }^{223}$ parece ser mais adequado utilizar-se o termo fides bona, de modo a evitar eventuais confusões conceituais.

\subsection{Transição como obra do pretor.}

Parte da doutrina romanística compreende a bona fides como noção equivalente à fides, o que caracterizaria a primeira como expressão tautológica, uma vez que o adjetivo bona não the acresceria nenhum tipo de significação. ${ }^{224}$

Conforme observa F. Schulz, a fides não poderia ter historicamente portado um significado neutro (como, por exemplo, valetudo ou venenum), tendo em vista que a deusa Fides tinha um templo no Campidoglio. Para o romanista alemão, mala fides - assim como Graeca fides ou Punica fides - importaria negação da fides. ${ }^{225}$

Nesse sentido, P. Frezza afirma ser insustentável a hipótese da superveniência de um valor normativo, antes inexistente, a indicar a passagem da fides à bona fides, tida como resultado de conferir-se à fides valoração de regra objetiva de responsabilidade nascente dos negócios de Direito privado. ${ }^{226}$

Esta corrente, portanto, não reconhece a existência de um processo de transição da noção de fides à outra noção de bona fides, assumindo-as como portadoras de um mesmo significado.

Não obstante seja evidente a proximidade entre a fides e a bona fides, deve-se reconhecer que esta última parece ser o produto de um processo evolutivo, uma vez que se caracteriza como uma norma jurídica de conteúdo preciso, enquanto a fides era apenas uma noção jurídica incipiente. ${ }^{227}$

\section{Cf. cap. IV.5.}

224. Cf. F. SChUl Z, Prinzipien cit. (nola 68 supra), p. 197. Nesse sentido, P. BONFANTE, Esserza cit. (nota 6 supra), p. 719 , afirma que a bona fides não seria mais do que a fides com a adição de um adjetivo costumeiro que não acresce propriamente nada ao conceito. Também na opinião de J. C. MURERRA ALVES, Direito cit. (nota 187 supra), p. 313, a bona fides pode ser entendida como sinônimo da fides, sendo um "conceito ético acolhido, sem modificação, pelo direito".

225. Cf. Prinzipien cit. (nota 68 supra), p. 197.

226. Cf. A proposito cit.(nota 185 supra), p. 300.

227. Cf. P. D. SinN, Buona fede cil. (nota 61 supra). p. 131. 
Essa evolução, dada a complexidade que the é inerente, seria artificial, uma obra humana voluntária. Mais do que isso, tratar-se-ia de uma criação hábil, tendo em vista que se escolheu a fides, um termo apto a preservar suas potencialidades técnicas sendo de extrema valia para os juristas - e sensibilizar imediatamente o leigo. De fato, a justaposição de fides, noção ligada a "poder", "confiança", "garantia" e "respeito" e com uma notável áurea mística, com bona revelam o sentimento de algo axiologicamente positivo. 228

Assim, em um certo ponto os juristas começaram a utilizar a bona fides como instrumento para a elaboração de algumas instituições de Direito contratual. Este fenômeno manifesta-se, incialmente, no século III a.C., conferindo logo aos bonae fidei iudicia o emprego da noção bona fides. ${ }^{229}$

As necessidades de aceleração do tráfico jurídico e, sobretudo. de manter relações contratuais com os peregrini (os quais não eram destinatários de normas de ius civile), teriam levado ao desenvolvimento da fides como elemento jurídico objetivo, por esta razão apelidada de bona. ${ }^{230}$

Era natural que essas necessidades .. cuja conseqüência jurídica, correspondente ao desenvolvimento da economia, era expressão da força vinculante da bona fides . estimulassem a criação de figuras concebidas para servir o tráfego universal, como é caso da compra e venda. ${ }^{231}$

Outrossim, também a própria assunção sob a égide da bona fides podia ser operada para negócios cuja origem não se vinculava, necessariamente, a relações com estrangeiros, por exemplo a sociedade e o mandato. Tais negócios eram reconhecidos, da mesma maneira, como merecedores da operatividade da bona fides, conseqüintemente podendo ser usados, indiferentemente, por cidadãos e estrangeiros. $^{232}$

228. Cf. A. M. R. Menezes Cordeiro, Da Boa-fé cit. (nota 5 supra), p. 101.

229. Cf. P. D. SENN, Buona fede cit. (nota 61 supra), p. 131 ; e Francisco AMARAL, A Boa-fé cit. (nola 8 supra). p, 200.

230. Cf. A. M. R. Menezes Cordeiro, Da Boa-fé cit. (nota 5 supra),, p. 91; e Cf. Francisco AMARAl, A Bua-fé cit. (nota 8 supra), p. 200.

23I. Cf. G. Grosso, Buona fede cit. (nota 74 supra), p. 662; e A. M. R. Menezes Cordero, Da Boa-fé cit. (nora 5 supra), p. 100.

232. Cf. G. Grosso, Buona fede cil. (nota 74 supra), p. 662. 
Finalmente, outros negócios jurídicos, como a tutela, que se caracterizavam por ser essencialmente aplicáveis a cidadãos romanos, também eram tutelados com base no esquema da bona fides. ${ }^{233}$

Nesse contexto, pode-se observar que realidades oriundas de periodos históricos diversos, com diferentes funções e âmbitos de aplicação, surgiram uniformizadas como fidei bona. ${ }^{234}$ Dessa forma, constatar-se-ia uma mesma força vinculante da bona fides para inúmeras relações entre cidadãos e entre cidadãos e estrangeiros. $^{235}$

Esse cenário não poderia ser obra do acaso; revelaria, em verdade, a assinatura indelével da comunidade humana organizada, dispondo de órgãos especializados para aplicar o seu engenho à reforma, meditada e pretendida, de relações sociais. $^{236}$

Ademais, considerando-se o fato de que o Direito Romano é extremamente pragmático, econômico quanto à adoção de reformas terminológicas ou similares, o recurso a expedientes lingüísticos inventivos só poderia ter advindo de uma necessidade de nominar realidades novas, criadas de modo especial. ${ }^{237}$

A expressão bona fides, portanto, teria sido uma inovação semântica criada pelo pretor, com um sentido técnico-jurídico, aproveitando o patrimônio sóciolingüístico da noção ćtico-moral da fides, profundamente enraizada na coletividade romana. $^{23 \gamma}$

Assim, em determinada altura, teria surgido a combinação bona fides, a qual, remetida ao juiz nas demandas tuteladas por bonae fidei iudicia, inserir-se-ia no sintagma oportet ex fide bona. ${ }^{239}$ Esta expressão, bastante simples, bastava para aclarar

233. Cf. A. M. R. Menezes Cordeiro. Da Boa-fé cit. (nota 5 supra), p. 100.

234. Cf. A. M. R. MEnezes Cordeiro, Da Boa-fé cil. (nola 5 supra), p. 100

235. Cf. G. Grosso, Buona fede cit. (nota 74 supra), p.662.

236. Cf. A. M. R. Menezes Cordeiro, Da Boa-fé cil. (nota 5 supra), p. 100; e A. CARCATERrA, Intorno cit. (nota 66 supra), p. 3-35.

237. Cf. A. M. R. Menezes Cordeiro, Da Boa-fé cit. (nola 5 supra), p. 101 ; e A. CARCATerra, Intorno cit. (nota 66 supra), p. 3-35.

238. Cf. A. ('arcaterra, Ancora cit. (nola 66 supra): p. 79; ¿ Francisco AMAral, A Boa-fé cit. (nota 8 supra), p. 204.

239. O conteúdo e as implicações do oportet ex fide bona surão examinados no cap. IV.3.6 infra 
ao destinatário, com precisão e eficácia, uma idéia complexa e técnica, qual seja a da bona fides. ${ }^{240}$

Mister observar, para que se possa compreender esse cenário, que o sistema jurídico romano tinha base processual, pois assentava na atribuição concreta de ações, e não no reconhecimento abstrato de posições jurídicas. Precisamente no campo processual teria havido a referida evolução fundada no labor pretoriano, em cujo decurso irromperia a bona fides, no âmbito dos bonae fidei indicia. ${ }^{241}$

\section{Bonae fidei iudicia.}

3.1 Considerações iniciais.

Após o exame da noção de bona fides, procederemos à análise dos juízos de boa-fé $\mathrm{f}^{242}$ (bonae fidei iudicia) no âmbito do sistema processual romano, nos quais, podem ser encontradas as principais aplicações da bona fides. ${ }^{243}$

Os bonae fidei iudicia - aos quais deve ser conferido amplo relevo, conforme observa V. Arangio-Ruiz ${ }^{244}$ - são uma categoria particular de juízos de procedimento criados no Período Clássico, caracterizados por adotarem uma fórmula

240. Cf. A. M. R. Menezes Cordeiro, Da Bua-fé cit. (nota 5 supra), p. 100-101.

241. Cf. A. M. R. Menezes Cordeiro, Da Boa-fé cit. (nota 5 supra), p. 71.

242. Na doutrina romanística, podem ser encontradas referências tanto à expressão "juízos de boafé" quanto a outra equivalente, qual seja "ações de boa-fé" Fxaminando a terminologia dos bonae fidei iudicia, F. SCHUL7, Classical Roman Law, 1951, trad. esp. De J. Santa Cruz Teigeiro, Derecho romano clásico, Barcelona, Bosch, 1960, p. 33. observa que a linguagem clássica conhece apenas esta expressão, e não as de bona fidei actio, bona fide iudicium, bona fidei contractus, bona fidei negotium. Assim, utilizaremos sempre a expressão "juízos de boa-fé". por ser a que melhor se coaduna com a tenninologia constante das fontes.

243. Cf. P. D. SenN, Buona jede cit. (nota 61 supra). p. I31; Franctsoo Amaral, A Boa-fé cit. (nota supra),, 203; e M. TALAMANCA, La 'bona fides' cit. (nota 10 supra), p. 40. A ponte-se que parte da doutrina romanistica afirma a aplicabilidade da boa-fé objetiva também fora do àmbito dos bonae fidei iudicia, ainda que com relevância menor. Nesse sentido, M. BRETONE. Storia cit. (nota 63 supra), p. 326, comenta a existência de um precioso documento acerca da questão: o capítulo XX da lex Rubria de Cália Cisalpina, provavelmente de $49-42$ a.C.

244. C.f. Istituzioni di diritto romano, 14 ed.. Napoli, Jovene, 1994, p. 298. 
na qual, mediante a aposição de uma cláusula especial, ordena-se ao juiz que ele sentencie em conformidade com os ditames da boa-fé. ${ }^{245}$

De fato, a invocação à boafé, consoante aponta Francisco. Amaral, passou a qualificar o processo como bonae fidei iudicia. ${ }^{246}$ No mesmo sentido, $M$. KASER observa que os juízos de boa-fé somente poderiam ser invocados no curso de um processo formulário, perfazendo um grupo das mais importantes relações obrigacionais cuja exigibilidade não se fundava na lei, mas na boa-fé (oportere ex fide bona), consoante as orientações de juristas e pretores. ${ }^{247}$

\subsection{Bonae Fidei Iudicia e Stricti Iuris Iudicia.}

Nas fontes ${ }^{2+8}$ encontra-se apontada uma contraposição entre bonae fidei iudicia e stricti iuris iudicia, ${ }^{249}$ a qual demonstra que os juristas clássicos teriam exaustivamente individualizado, já a partir do fim da época republicana, a categoria dos juizos de boa-fé. 250

Não obstante o fato de a distinção entre relações jurídicas bonae fidei e stricti iuris ser substancial, deriva ela da adição de apenas três palavras na fórmula da ação bonae fidei: ex fide bonu. ${ }^{251}$

245. Cf. P. D. SENN, Buona fede cit. (nota 61 supra), p. 13 I ; A. M. R. MeNezesCoRDeiro, Da Boafé cit. (nota 5 supra),, p. 73; F. SCHULZ, Classical, cit. (nota 243 supra). p. 33-34; e P. VoCl Mamale di diritlo romano, $2^{\mathrm{a}}$ ed., vol. I, Milano, Guffrè. p. 112.

246. Cf. A Boa-fé cit. (nota 8 supra), p. 200.

247. Cf. Das römische's cit. (nola 61 supra), p. 37.

248. Notadamete em I. 4. 6, 28. Cf. M. TALAMANCA. Processo civile (diritto romano) in ED 36 (1959), p. 64; FRANCISCO AMARAL, A Boa-fé cit. (nola 8 supra), p. 202; e V. ARANGlO-RUT, Istituzioni cit. (nola 245 supra), p. 299

249. Juizos stricti iuris, stricti iudicii ou iudicia stricıa. denominações próprias da linguagem pósclássica. Cf. A. D'ORS, Elementos de derecho privado romano. $2^{3} \mathrm{ed}$, Pamplona. Universidad de Navarra, 1975, p. 60.

250. Cf. M. TAlamanCA, Processo cit. (nota 249 supru). p. 64; A. D'ORS. Flementos cit. (nota 250 supra), p. 60; e V. ARANGIO-RUIZ, Istilluzioni cil. (nota 245 supra), p. 299.

251. Cf. B. Nicholas, An Introduction to Roman Law. Cambridge, Clarendun, 1975, p. 163. 
Nos juizos que não podiam ser caractarizados como bonae fidei perfazendo stricti iuris iudicia, portanto - o magistrado deveria julgar rigorosamente de acordo com a pretensão enunciada pelo autor da demanda. ${ }^{252}$

O officium iudicis estava, assim, extremamente limitado a dizer "sim" ou "não" sobre a existência ou inexistência do direito do demandante. Eventuais circunstâncias do caso concreto apenas deveriam ser ponderadas se inseridas pelo pretor na exceptio da fórmula processual. ${ }^{253}$

\subsection{Processo formular e expansão comercial.}

As ações de boa-fé surgiram, consoante observam F. Amaral e P D. SENN, em um momento fundamental da história do Direito Romano: aquele no qual as leges actiones (ações da lei) ${ }^{254}$ - insuficientes para tutelar todas as situações jurídicas estavam sendo progressivamente suplantadas pelo processo formular. ${ }^{255}$

Como observa M. Bretone, este novo processo conservou a distinção em dois estados (in iure e apud iudicem), mas não se vinculou aos rígidos modelos das legis actiones. e adotou como instrumento a formula (ou iudicium), ${ }^{256}$ à qual as partes submetiam-se com a litis contestatio. A controvérsia era, na fórmula, reassumida pelo magistrado em termos precisos, após um livre debate entre as partes, mantido perante ele, que fornece ao juiı o esquema para a decisão. ${ }^{257}$

As fórmulas dos juizos - e também as das exceptiones, dos interdicta e das stipulationes praetoriae, dentre outros - eram enunciadas no edito pelo pretor e

252. Cf. M. TAlamanCa, Processo cit. (nota 249 supra). p. 64.

253. Cf. A. S. Justo, Direito Privado Romano, vol. I. Coimbra, Coimbra 2000, p. 245. O esuuema do processo formular será examinado nos caps. IV.3.3 e IV.3.6.

254. U mais antigo sistema processual romano, caracterizado por ser excessivamente formalista e rigido, adotando rituais solenes e apresentando intimo relacionamento com a religião (fas). Cf. JosÉ Rogério CRUz e TuCCI - LuIz CARlos de AzEvedo, Lições de História do Processo Civil Romano, São Paulo, RT, 1996, p. 41. Este sistema processual foi abolido, salvo raras exceções - pela lex lulia, de 17 a.C. Cf. M. TALAMANCA, La repubblica in Lineamenti di storia del diritto romano, Mario Talamanca (org.), Milano, Giuffrè, 1979. p. 168.

255. Cf. Francisco Amaral, A Boa-fé cit. (nota 8 supra), p. 203.

256. Cf. JOSÉ ROGÉRIO CRUZ E T UCCl - LUIZ CAR LOS DE AZEVEDO, Liỗes cit. (nota 255 supra), p. I00.

257. Cf. Storia cit. (nola 63 supra), 104; e JosÉ RogÉrio CRUZ e TUCCI - LUIZ CARLOS DE AZEVFDO. Liçôes cit. (nota 255 supra), 100. 
visavam a tutelar situações subjetivas não contempladas pelo ius civile. A partir da lex Aebutia, contudo, o pretor deveria considerar, no edito, também os pressupostos fáticos dos ius civile para os quais se poderia, com efeitos civilísticos. agere per formulas. ${ }^{258}$

A introdução das fórmulas escritas, portanto, implicou o surgimento de um novo tipo de processo, o qual adotava procedimentos de conteúdo variável, menos rígidos e mais adaptados aos reclamos da comunidade. ${ }^{259}$

Desde momentos históricos arcaicos Roma manteve contatos comerciais com outros povos, ${ }^{260}$ e houve relações jurídicas entre cidadãos (cives) e peregrinos (hostes, peregrini), consoante alusões constantes da XII Tab.. ${ }^{261}$

Contudo, a notável expansão romana na península itálica, no Mediterrâneo e em diversas outras regiões européias (sécs. III a.C. a I d.C) propiciou níveis inéditos de desenvolvimento das atividades econômicas (comerciais, financeiras, artesanais, minerais e operárias) de Roma. Esta nova realidade acarretou a multiplicação de relações jurídicas entre cidadãos romanos, entre romanos e peregrinos, e entre os próprios peregrinos. ${ }^{262}$

Nesse passo. conforme observa A. M. R. Menezes Cordeiro, as mutações econômico-sociais, anunciadas logo no início da expansão territorial romana, provocaram reformas jurídicas realizadas pela instância pretoriana. ${ }^{263}$

Com efeito, dentre os primeiros efeitos da ampliação das relações comerciais de Roma, conforme aponta V Arangio-Ruiz, consta a instituição, em 242 a.C., ${ }^{264}$ de um novo tipo de pretor, o qual tinha jurisdição sobre as relações mantidas entre romanos e estrangeiros: preator qui inter cives et peregrinus ius dicit ou, mais brevemente, praetor peregrinus. ${ }^{265} \mathrm{~A}$ jurisdição do pretor peregrino teria consolidado o

258. Cf. M. TAL.AMANCA, La repubblica cil. (nola 255 supra), p. 168.

259. Cf. JOSÉ Rogt́RIO CRUZ E TUCCI - Luiz Carlos de Azeredo, Liçòes cit. (nota 255 supra). p. 47.

260. Basta lembrar que já em 509 a.C. Roma e Cartago celebraram um tratado comercial. ('f.F. DE. MARINI AVONZO, Lezioni di storia del dirilto romano, Padova, CEDAM, 1999, p. 125.

261. Cf. J. Pariclo, Hisloria cit. (nola 65 supra). p. 95.

262. Cf. G. PUGLIESE, Istituzioni cit. (nota 219 supra), p. 505.

263. Cf. Da Boa-fé cit. (nola 5 supra). 103.

264. Data aproximada do final da Primeira Guerra Púnica, quarenta anus antes da conclusão da segunda com a vitória definitiva sobre Cartago. Cf. M. BRETONE. Storia cit. (nota 63 supra), p. 104.

265. Cf. Storia del diritto romano, $7^{3}$ ed., Napoli, Jovene, 1984, p. 145. No mesmo sentido, Francisco Amaral, A Boa-fé cit. (nota 8 supra), p. 200. 
processo formular, suplantando o antigo sistema também no tribunal do pretor urbano. $^{260}$

Dessa forma, o pretor peregrino tinha o dever de administrar a justiça entre estrangeiros e entre romanos e estrangeiros; a tal pretor cabia a nomeação dos juízes, os quais tinham uma liberdade de apreciação das demandas bastante ampla. ${ }^{267}$ Diante do tribunal do referido magistrado as partes não pronunciavam, como era conduta exigida ante o pretor urbano, as palavras sacramentais da legis actio, mas exprimiam sua pretensões recíprocas da forma como thes conviesse, servindo-se, quando necessário, de intérpretes. ${ }^{268}$

Fm tal cenário, foi possivel fazer valer para e contra os peregrinos situações subjetivas reconhecidas nas regras consuetudinárias aplicadas nos mercados ou através de relações comerciais ou financeiras internacionais. Para esta finalidade, todavia, uma vez que muitas destas regras, mais que jurídicas, eram ético-sociais - por exemplo aquelas atinentes à emptio venditio (compra e venda) e fundavam-se na fides, foi necessário que o pretor peregrino esquematizasse uma fórmula que obrigasse o órgão judicante a pronunciar-se segundo a fides bona. ${ }^{269}$

\subsection{Origem.}

Com base nas considerações acima apresentadas, referentes à realidade histórica na qual se inseriu o surgimento dos bonae fidei iudicia, proceder-se-á à análise da origem destes juízos. ${ }^{270}$ Nomeadamente, examinar-se-ão duas possibilidades: (i) a de tratar-se de produto do ius gentium; e (ii) a de estar-se diante de criação pretoriana.

266. Cf. M. BRETONE, Storia cit. (nota 63 supra), 104.

267. Cf. M. BRETONE, Storia cit. (nota 63 supra), 104.

268. V. ARANGIO-Ruiz. Storia cit. (nota 266 supra), p. 145.

269. Cf. G. PUGl.IESE, Istiluzioni cit. (nota 219 supra). p. 209.

270. Há, na doutrina, uma calorosa discussão acerca da origem i natureza dos bonaefidei iudicia. As divergincias apresentadas pelas posições que têm sido assumidas, conforme observa A. M. R. MENEZES CORDEIRO, Da Boa-fé cit. (nora 5 supra). p. 90. não podem ser solucionadas por meio de um trabalho puramente histórico de reconstrução das fontes. 
Como se viu, o traço saliente dos bonae fidei iudicia, segundo a communis opinio, teria sido a sua aplicabilidade tanto a cives quanto a peregrini, configurando-se assim como iudicia universais. ${ }^{271}$

A afirmação de tal universalidade surge natural, uma vez que a fides seria um dado extrajurídico, ético-social e, como tal, insensível às restrições próprias do ius civile; implicaria todos os indivíduos que, honestamente, estivessem adstritos a certa conduta. De fato, conforme observa A. M. R. Menezes Cordeiro, sendo a recepção dos bonae fidei iudicia - em esquemas jurídicos - precedida da criação do praetor peregrinus, nada mais razoável do que esperar um âmbito geral de incidência. ${ }^{272}$

Dessa forma, os bonae fidei iudicia estavam a serviço, especialmente, das relações entre cidadãos romanos. Todavia, em virtude do fato de que não estariam baseadas na lei, mas em obrigações de boa-fé (oportere ex fide bona), seriam também aplicáveis a peregrinos. ${ }^{273}$ Isto porque, conforme aponta M. Kaser, o vínculo da boa-fé estender-se-ia a todos os homens, cidadãos e não cidadãos. ${ }^{274}$

Este entendimento, consoante adverte A. M. R. Menezes Cordeiro, deve ser matizado, pois nem todos os institutos bonae fidei iudicia eram, inicialmente. aplicáveis a cives e peregrini. ${ }^{275}$ Com efeito, M. Kaser aponta que, dentre outros institutos, a fiducia e a tutela teriam inicialmente ficado limitadas a cidadãos romanos. ${ }^{276}$ Posição semelhante adota J. Paricio, ao afirmar que havia instituições jurídicas dotadas de um rigoroso formalismo (como a mancipatio e a sponsio), exclusivas do Direito aplicável aos cidadãos romanos. ${ }^{277}$

Não obstante. o sentido geral da evolução dos bonae fidei iudicia foi o de uma aplicação cada vez mais extensa, com vocação de universalidade. Esta evolução justificar-se-ia na medida em que os bonae fidei iudicia sempre estiveram estritamente

271. Consoante adverte A. M. R. MENI ZES CORdeIRO, Da Boa-fé cit. (nola 5 supra). p. 82. deve-se preferir a expressão "universal" à qualificação habitual dos bonae fidei iudicia como juízos de ius gentium, uma vez que esta categoria surgiu muito depois da criação daqueles.

272. Cf. Da Boa-fé cit. (nola 5 supra), p. 83.

273. Cf. M. KASER, Das römisches cit. (nota 61 supra), p. 50.

274. Os cidadãos sempre tiveram acesso aos bonae fidei iudicia; para os não cidadãos, outros juizos foram criados. destinados apenas a eles. Cf. Das römisches cit. (nota 61 supra), p. 37.

275. Cf. Da Boa-fé cit. (nota 5 supra). p. 83.

276. Cf. Das römisches cil. (nola 6I supra), p. 51; 200.

277. Cf. J. Paricio. Historia cit. (nola 65 supra), p. 95-96. 
ligados ao desenvolvimento comercial e a progressos, ${ }^{278}$ contribuindo sobremaneira para a modernização e desnacionalização do Direito privado, o que facilitou a aplicação deste em todas as partes do Império Romano. ${ }^{279}$

A mencionada vocação de universalidade traz em si um importante desdobramento, concernente à relação existente entre os bonae fidei iudicia e o ius gentium. Especificamente, deve-se examinar a possibilidade de tal Direito ter produzido os juíos de boa-fé. Para tanto, necessário se que se façam algumas considerações acerca da noção de ius gentium. ${ }^{280}$

Em que pese o fato de ao ius gentium poderem ser dadas conotações diversas, ${ }^{281}$ tem-se hoje por assente que nele se agrupavam instituições consideradas, pelos romanos, comuns a todos os povos com os quais mantinham relações. ${ }^{282}$ Estas relações, notadamente comerciais, beneficiaram-se do conjunto de normas mais simples e flexíveis do ius gentium, distantes das antigas formas solenes, aplicáveis a todos os homens, sem distinção de nacionalidade. ${ }^{283}$

Para proceder à distinção deste Dircito comum em relação ao Direito que regulava as relações entre romanos (ius civile), recebeu ele a denominação de ius gentium. Esta antitese, em verdade, configura-se mais como um labor doutrinário, realizado pelos fílósofos, do que como uma classificação criada pela jurisprudência. Não se trata, portanto, de um Direito dos estrangeiros, senão a um Direitu que. embora fosse romano, resultava acessivel a estes. ${ }^{284}$

278. Cf. A. M. R. MENEzes CORdeiro, Da Boa-fó cil. (nota 5 supra), p. 83.

279. Cf. M. KASER, Das römisches cit. (nota 61 supra), p. 51: 200.

280. A dicotomia conceitual entre ius civile e ius gentium é amplamente reconhecida e documentada. sobretudo na época do Império. Cf. M. TALAMANCA, La repubblica cit. (nota 255 supra), p. 171.

281. A. M. R. MEvezes Curdeiro. Da Boa-fé cit. (nota 5 supra). p. 95, observa que três conotaçües conferidas ao ius gentium merecem destaque: (i) o Direito das relaçőes dos peregrinos com os romanos; (ii) o conjunto das instituições comuns a todos os povos; e (iii) o Direito das relações entre os Estados.

282. Cf. A. M. R. Menezes Cordeiro, Da Boa-fé cit. (nota 5 supra), p. 95: e F. De MARINI Avonzo, Lezioni cit. (nola 261 supra), p. 124.

283. Cf. FrancisCo AMARAI, A Boa-fé cit. (nota 8 supra), p. 200.

284. Cf. J. PARICIO, Historia cit. (nota 05 supra). p. 95-96: e V. ARANGio-RLE Storia cil. (nota 260 supra), p. 145. 
De qualquer forma, o ius gentium apenas teria começado a enquadrar as relações entre romanos e peregrinos a partir do séc. II d.C., muito após a criação dos primeiros juizos de boa-fé, a qual remonta ao séc. III a. C. ${ }^{285}$

O lapso histórico existente entre a criação dos bonae fidei iudicia e o surgimento do ius gentium é tomado por fundamento por A. M. R. Menezes Cordeiro para declarar que a referência persistente ao ius gentium, a propósito da origem a natureza da fides bona, deve, definitivamente, ser evitada. ${ }^{286}$ Nesse sentido também se manilesta $\mathrm{M}$. Bretone, observando que haveria uma relação de confirmação, ¿ não de criação do juízos de boa-fé pelo ius gentium. ${ }^{287}$

Assim, parece correto afirmar que não foi o ius gentium que produziu os bonae fidei iudicia. Na verdade, o fato de as relações entre romanos ¿ peregrinos tercm se baseado em grande parte na fides bona é que teria levado as pretensões respectivas à inclusão no ius gentium.

A fastada a possibilidade de os bonae fidei iudicia terem sido um produto do ius gentium, cumpre estudar uma segunda tese concernente à origem de tais juizos. qual seja aquela referente à possibilidade de tratar-se de uma criação pretoriana.

Em relação a esta possibilidade. as divergências podem ser sintetizadas em duas teses: (i) a de ter havido uma juridificação dos bonae fidei iudiciu derivada da fides bona (com reconhecimento posterior pelo pretor) e a de ter ocorrido uma positivação por força do pretor (ou seja, a de os bonue fidei iudicia serem fruto de criação do pretor. ${ }^{288}$

A primeira tese procura demonstrar a pré-existência de costumes comerciais captados pelo praetor peregrinus, os quais, por estarcm já radicados, foram recebidos no ius civile e não no ius honorarium. ${ }^{289}$

Este entendimento é defendido por V. Arangio-Ruiz, o qual entende que a origem dos bonae fidei iudicia residiria no agrupamento de costumes comerciais

285. Cf. cap. IV.3.5 infra.

286. Cf. Da Boa-fé cit. (nota 5 supra), p. 96.

287. Cf. Storia cit. (nota 63 supra). p. 105.

288. Cf. A. M. R. MENezes Cordeiro, Da Bou-fé cit. (nota 5 supra), p. 92.

289. Simplificadamente, a contraposiçào entre ius civile e ius honorarium funda-se no fato de que o segundo tinha como fonte exclusiva o edito do pretor, enquanto o primeiro baseava-se em fontes diversas como a XII Tab. e as leges. Cf. M. TALAMANCA, La repuhhlica cit. (nora 255 supra), p. 171. 
como bona fides, reconhecidos pelo pretor peregrino e, depois, pelo urbano. Para o romanista, os contratos nascidos no âmbito do comércio internacional e tutelados pelo pretor peregrino não poderiam adotar um oportere puro e simples, expressão que indicava uma obrigação concernente ao ius civile Romanorum. Isto porque as obrigações comerciais eram fundadas sobre a fidúcia recíproca que era necessária entre os comerciantes habituados a encontros nos mercados de diversos países. ${ }^{290}$

M. Bretone acolhe esta opinião, observando que o pretor, ao inserir no seu edito os juizos de boa-fé que lhe dizem respeito, sabe que está se referindo a experiências já entendidas, pelos menos em uma certa medida, como jurídicas. Para o autor, tudo levaria a supor, por exemplo, que mercadores romanos e estrangeiros que estipulavam uma compra e venda, em Roma ou Alexandria, considerassem o vínculo independentemente da tutela magistratural. ${ }^{291}$

Assim, a origem pretória dos bonae fidei iudicia é considerada improvável por M. Bretone, o qual afirma ser mais plausivel a explicação de que eles permaneceram sempre estranhos ao Direito pretório. Corroboraria este entendimento o significativo fato de que tais juízos não tinham cláusulas editais de introdução. ${ }^{292}$

A estrutura dos bonae fidei iudicia serve de fundamento também a Francisco Amaral para justificar a preexistência destes juizos, revelada pelo conteúdo na intentio. Para o autor, o termo oportet indicaria a existência de um dever com origem em um sistema de valores anteriores à concessão da ação por parte do pretor, o que comprovaria não se tratar de ação pretoriana. ${ }^{293}$

Também J. Paricio considera improvável a tese de que os juízos de boafé tiveram origem na práxis do tribunal do pretor peregrino, afirmando que tais juizos devem ter se originado nas relações entre cidadãos. De qualquer forma, observa o

290. Cf. Istituzioni cit. (nota 245 supra), p. 298.

29I. Cf. Storia cit. (nota 63 supra), p. 102-105, não afasta a possibilidade de ter-se encontrado, antes da instituição do pretor peregrino. maneira de tutelar tais juizos, por meio de compromissos e arbitragens. ou atravis da própria jurisdição do pretor urbano; inegável para o autor. todavia, o fato de que o advento do pretor peregrino marca o inicio de uma nova lase. A possibilidade de ter havido tutelas alternativas é também aventada por V. ARANGIO-RUIZ, Istituzioni cil. (nula 245 supra). p. 298: e J. PARICIO, Historia cil. (nota 65 supra). p. 96.

292. Cf. Storia cit. (nota 63 supra). p. 326.

293. Cf. Francisco Amaral, A Boa-fé cir. (nola 8 supra), . p. 202); e P. D. Senn, Buona fede cil. (nola 61 supra), p. 131. 
romanista, as ações de boa-fé foram sempre civis; a recepção pretoriana não as converteu em honorárias. ${ }^{294}$

Nessa primeira orientação, portanto, as realidades juridicas bonae fidei ter-seiam imposto por si próprias. O pretor apenas teria recebido e reconhecido tais realidades, e não as criado, motivo pelo qual não poderiam ser consideradas como figuras de Direito honorário. ${ }^{295}$

Esta corrente, para A. M. R. Menezes Cordeiro, não tem apoio nas fontes, e coaduna-se mal com o espírito do Direito Romano. Na falta de elementos históricos, seria pura conjectura a afirmação da precedência de práticas consuetudinárias $\mathrm{em}$ relação à aproximação das realidades imegradas nos bonae fidei iudicia. Ademais, deve-se considerar a dificuldade em conseguir, por via consuetudinária, algo que se aproxime da complexa teia de relações contidas nos bonae fidei iudicia. Finalmente, a viabilidade da referida tese seria comprometida pela aversão tradicional do Direito Romano ao costume, patente em todo o processo que culminou com a XII Tab. ${ }^{296}$

De outra parte, a segunda orientação, prevalecente na doutrina, ${ }^{297}$ alega que a criação pretoriana dos bonae fidei iudicia teria se processado através dos meios honorários típicos. O pretor, simplesmente, teria aproveitado realidades juridificadas pela própria fides e, posteriormente, a novidade fides bona teria sido recebida no ius civile.

Assim, segundo esta teoria, o pretor limitar-se-ia a oficializar o que já ocorria de fato, mercê da própria fides, a qual seria o próprio fundamento da pretensão levada a juízo. Em outras palavras, a fides, enquanto representação fundamental da ordem social romana á época da República, teria conduzido ao surgimento de uma séria de pretensões éticas e morais, mais tarde reconhecidas pelo pretor. ${ }^{298}$

294. Cf. Historia cit. (nola 65 supra), p. 96.

295. Cf. A. M. R. MENEZes CORDeIRo, Da Boa-fé cil. (nota 5 supra), p. 92.

296. Cf. Da Bua-fé cit. (nota 5 supra), p. 96-97.

297. Cf. M. TAlamanca, La 'bona fides' cit. (nota 10 supra), p. 42ss; G. Pugliese, lstincioni cit (nota 219 supra). p. 506; M. KASER, Das römisches cit. (nota 61 supra), p. 26-37; P.D. SENN, Buona fede cit. (nola 61 supra), p. 132; e A. M. R. MENEzES CORDEIRO, Da Boa-fé cit. (nola 5 supra), p. 94 ss.

298. Cf. A. M. R. Menezes Cordeiro, Da Boa-fé cit. (nota 5 supra), p. 94-95. 
Nesse passo, de acordo com G. Pugliese, os bonae fidei iudicia devem ser vistos como uma contribuição essencial dos pretores, sob a orientação dos juristas, que conferiram valor jurídico às obrigações e aos institutos éticos-sociais inspirados na fides. ${ }^{299}$

De fato, o surgimento das ações de boa-fé foi contemporâneo ao nascimento da idéia de trocas obrigacionais. Anteriormente. o Direito romano não conhecia outra noção que não a de escambo real, da qual a mancipatio é o protótipo; a stipulatio, de outra parte, produzia apenas obrigações unilaterais. A troca obrigacional, dessa forma, não poderia ser agasalhada, por via meramente interpretativa, por qualquer dos modelos preexistentes. Fazia-se necessária a criação de uma nova categoria jurídica. precisamente aquela dos juízos de boa-fé. ${ }^{300}$

Contrapondo as duas orientações, pode-se concluir pela melhor fundamentação da segunda, reconhecendo que as regras aplicáveis aos bonae fidei iudicia teriam natureza pretoriana. Diversos fatores atestariam a veracidade desse entendimento, como a consagração de muitas dessas regras na instância do pretor peregrino. com a universalidade subseqüente, e a criação, pelo pretor. do dolus (com as conseqüentes implicações nas outras exceptiones). ${ }^{301}$

O novo regime teria sido precisado pelo pretor. com apoio nos jurisprudentes, de tal forma que a inclusão do ex fide bona na fórmula corresponderia a instruções concretas e precisas dadas ao juì. Todas as implicações dos bonae fidei iudicia não surgiram no mesmo ensejo; foram, porém, sempre de criação voluntarística, puramente jurídica. ${ }^{302}$

A dialética entre os estímulos - provenientes da sociedade e da abertura cultural - às inovações e o influxo da tradição, particularmente forte na sociedade romana, encontrava na atividade criativa dos pretores uma janela para que o primeiro contrapeso pudesse prevalecer. ${ }^{303}$

299. Cf. Istituzioni cit. (nota 219 supra), p. 506.

300. P. D. SENN. Buona fede cit. (nota 61 supra), p. 132.

301. Cf. A. M. R. Menezes CORdeiro, Da Boa-fé cil. (nola 5 supra), p. 103. A questão das exceptiones será discutida no cap. IV.3.6 infra

302. As conclusões acima têm apoio direto nas fontes. notadamente Ulp. 11 aded. D. 4,3, 1,3 e Cic. De off. 3, 17, 70; 3, 14, 60. Cf. A. M. R. Menezes Cordeiro. Da Bou-fécit. (nola 5 stpra), p. 103-104.

303. Cf. M. TAlAMANCA, La 'bona fides' cit. (nola lo supra), p. 48. 
O recurso à bona fides representava para o pretor uma escolha praticamente inafastável, tendo em vista que o formalismo tradicional do ius civile inviabilizava a tutela jurídica das relações comerciais, sobretudo no que diz respeito ao respeito à palavra dada e à conferência de eficácia vinculante aos meros acordos. ${ }^{304}$

Com base no exposto, parece assentado reconhecer-se que a gênese da bona fides reside nos bonae fidei iudicia. Isso porque a bona fides seria o resultado de trabalho criativo dos pretores voltado à constituição de uma nova noção jurídica, a qual serviria de base para um sistema processual apto a tutelar as relaçōes jurídicas surgidas na realidade da expansão comercial romana. ${ }^{305}$

\subsection{Elenco.}

Uma vez examinada a origem dos bonae fidei iudicia, importa determinar quais juízos enquadravam-se nesta categoria. Trata-se de verdadeira vexata quacstio, uma vez que a extensão dos elencos e a qualificação de alguns juízos como de boa-fé continuam a provocar amplas divergências entre os romanistas. ${ }^{306}$

Parte da doutrina romanística apresenta elencos bastante restritos de juizos de boa-fé. Assim, E. Chamoun aponta que eram tuteladas por bonae fidei iudicia os contratos de fídúcia, depósito, comodato e penhor, ressaltando que paira incerteza sobre a inclusão do último. ${ }^{307}$ B. Biondi aponta elenco um pouco mais extenso, incluindo os juízos referentes aos contratos de compra e venda, locação, sociedade e mandato. Em relação aos demais juizos normalemente apontados pela doutrina, o romanista observa que eles não apresentavam enquadramento nem denominação uniformes. $^{308}$

O exame das fontes, contudo, sugere que diversos outros institutos juridicos romanos passaram paulatinamente a ser tutelados por juízos de boa-fé. Sem

304. Cf. M. TAlamanCA, Lu 'bona fides' cit. (nota 10 supra), p. 45.

305. Cf. P. D. SENN, Buona jede cit. (nota 61 supra), p. 131 ; Francisco AMARAL. 1 Boa-fe cit. Inota 8 supra),, 203; c M. TAlamanCA, La bona fides cit. (nota supra), p. 40. Em sentido contrário,

306. Cl. G. GRosso, Buona fede cit. (nota 74 supra), p. 663; A. M. R. MENEZESCORDEIRO, Da Boafé cit. (nola 5 supra), p. 74; e F. SCHULz, Classical cit. (nota 243 supra). p. 35.

307. Cf. Ebert Chamoun, Instituições de Direito Romano, $3^{a}$ ed.. Rio de Janeiro, Forense, 1957, p. 342.

308. Cf. B. Biondi, Contrato e Stipulatio - Corso di lezioni, Milano. Giuffie, 1953, p. 238. 
perder de vista a advertência fuita pelos especialistas, concernente às divergências provocadas pela análise das fontes em relação ao tema, procuraremos apresentar breves considerações de cunho comparatístico acerca dos elencos dos bonae fidei iudicia.

O mais antigo bonae fidei iudiciae remontaria ao séc III a.C, tutelando o pactum fiduciae, instituto bastante antigo, contudo não previsto na XII Tab.. ${ }^{309}$ o qual teria servido, de certa maneira, de modelo para os juízos de boa-fé. ${ }^{310}$

De forma sucessiva, outras ações desta natureza teriam sido introduzidas na sistemática processual romana: no séc. II a.C., ações para a compra e venda (emptiovenditio), locatio conductio, societas, negotiorum gestio. e mundatum. Já na época republicana, teriam advindo ações de tutela do comodato. do depósito e de penhor. ${ }^{311}$

Conforme se pode inferir, entre os juizos de boa-fé mais antigos constam em maioria institutos ligados ao prisma semântico de poder da fides dos períodos arcaico e pré-clássico. Tais institutos apresentariam, todavia, uma natureza jurídica e técnica, que a fides antiga. descolorida, seria incapaz de. por si, traduzir. ${ }^{312}$

Ao final da época clássica o elenco das ações de boa-fé já era consideravelmente extenso. Nesse sentido, Cícero indicava uma relação, atribuída a Quinto Múcio, que compreendia tutela, sociedade, fidúcia, mandato, compra e venda. locatio conductio, equiparando a estas a actio rei uxoriae (dote). ${ }^{313}$

Consoante observa A. M. R. Menezes Cordeiro, na enumeração de Cícero nota-se uma seqüência que, projetando para o fim os contratos fontes de ações respectivas (compra e venda e condução-locação), deixa no primeiro lugar a tutela, a

309. Cf. FRancisco Amaral, A Boa-fé cit. (nota 8 supra), p. 202. Conforme adverte P.D. SENN, Buona fede cit. (nota 61 supra), p. 133, essc pactum, modemamente, não é mais considerado um contrato pelos especialistas, sob o argumento de que consistia em uma convenção acessória a uma mancipatio, mediante a qual as partes acordavam acerca da nova transferência da propriedade au alienante, sob determinadas condições. De qualquer forma, observa o autor, o pactum fiduciae possuia as características genéricas de um contrato. e a elaboração daquele teria sido o ponto de partida da criação dos contratos consensuais.

310. Cf. A. D’OrS, Elementos cit. (nota 250 supra), p. 60.

311. Cf. P. D. Senn, Buona jede cit. (nota 61 supra), p. 133; e Francisco Amaral. A Boa-fé cit. (nota 8 supra), p. 202.

312. Cf. A. M. R. Menezes Cordeiro, Da Boa-fé cit. (nota supra), p. 78.

313. Cf. De. off. 3. 17, 70. Em relação ao tema, cf. os comentários de G. Grussu. Buona fede cit. (nola 74 supra), p. 663; A. M. R. MENEZES CORDEIRO. Da Boa-fé cit. (nota 5 supra), p. 74; F. S(7ULZ. Classical cit. (nota 243 supra), p. 35; A. S. JUsto, Direito Privado cit. (nola 254 supra), p. 246-247; M. KASER, Das römisches cit. (nota 61 supra), p. 200; e A. D'ORS. Elementos cit. (nota 250 supra), p. 60. 
sociedade, a fidúcia e o mandato. Em qualquer destas quatro figuras juridicas, seria patente a ligação pessoal dos intervenientes, em vez da mera permuta econômica das outras duas. 314

O catálogo constante de Gai. $(4,62)^{315}$ incluía as ações para compra e venda, locação, gestão de negócios, mandato, depósito, fidúcia, sociedade, tutela e ações divisórias. ${ }^{316} \mathrm{~A}$ ausência da ação referente ao comodato (actio commodati in ius) seria injustificada, e tem sido considerada pela doutrina como um erro do copista. ${ }^{317}$

Fm I. $(4,6,28)^{318}$ o catálogo, em que pese năo mais incluir a actio fíduciae e a actio rei uxoriae, acrescentava a actio praescriptio verbis, ${ }^{319}$ além das ações voltadas aos contratos inominados, de penhor, de divisão de herança, de divisão de coisa comum, de permuta e de aestimatum. ${ }^{320}$ Salvo a hipótese de lapso nos textos

314. Cf. Da Boa-fé cit. (nota 5 supra), p. 77-78. O autor afirma ser plausivel a possibilidade de a condenação nos quatro iudicia em causa acarretar infâmia.

315. "Sunt autembonae fidei iudicia haec: ex empto venditio, locatio conductio, negntiorum gestorum, mandati, depositi, fiduciae, pro socio, tutelue, rei uxuriae".

316. Cf. A. S. Justo, Direito Privado cit. (nota 254 supra), p. 246-247. Nesse sentido, cf. tb. M. KASER, Das römisches cit. (nota 61 supra), p. 200.

317. Cf. J. ZABLOCKI, Ex fide bona nella formula del comodato, in Il ruolo della buona fede oggetiva nell 'esperienza giuridica storica e contemporanea, vol. IV, Luigi Garofalo (org.), Padova, CEDAM, 2003, p. 457; Nesse sentido, também se posicionam FranCiSCO AMARAL, A Boa-fécil. (nola 8supra), p. 202; e P. D. SENN, Buona jede cit. (nota 61 supra), p. 133. F. SCHULZ, Classical cit. (nota 243 supra), p. 35, também aponta posíveis equívocos no elenco de Gaio. G. GROSSO, Buona fede cit. (nota 74 supra), p. 663, por seu turno, considera ainda a possibilidade de o catálogo de Gaio incluir a actio pigneraticia in ius.

318. "Actionum autem quaedam bonae fidei sunt, quaedam sctricti iuris. Bonae fidei sumt hae: ex emptio venditio, locatio conductio, negotiorum gestorum, mandati, depositi, pro sócio, tutelae, commodati, pigneraticiu, familiae erciscundae, communi dividendo, praescriptis verbis, quae de aestimatio proponitur, et ea, quae ex permutatione competit, el hereditatis p'titio. quamvis enim usque adhuc incertum erut, sive interbonae fidei iudiciu connumerandu sit sive non, nustru tamen constitutio apente eam esse bonae fidei disposuit"

319. Trata-se de ação geral para os contratos inominados, introduzida pela jurisprudência no inicio do séc. II, conforme se depreende de Ulp. 4 ad ed., D. 2, 14, 7, 2.

320. Cf. A. M. R. Menezes Cordeiro, Da Boa-fé cit. (nota 5 supra), p. 75; A. S. Justo, Direito Privado cit. (nota 254 supra), p. 246-247; M. KASER, Das römisches cil. (nota 6I supra), p. 200; Alexandre Correia - Gaetano Sciascia, Manual de Direito Romano, $2^{a}$ ed., vol. I, São Paulu, Saraiva, 1953. p. 103; FranCISCO AMARAL, A Boa-fé cit. (nola 8 supra), p. 202-203; e P. D. SENn, Buona fede cit. (nota 61 supra). p. 133. Para G. Grosso, Buona fede cit. (nota 74 supra), p. 663, também extaria incluida a actio ex stipulatu (que havia substituido a actio rei uxoriae). 
das fontes, parece correto afirmar que se está diante de uma evolução do elenco, o qual teria se alargado. ${ }^{321}$

As tentativas de elaboração de um elenco dos bonae fidei iudicia são veemementementc criticadas por F. Schulz, que rejeita a possibilidade de listá-los. Para o autor, o edito pretoriano conteria uma seção de tais juízos, mas esta não seria completa. Também pairariam dúvidas quanto à relação formulada por Gaio, ${ }^{322}$ a qual não estaria isenta de caprichos e arbitrariedades históricas, ainda que pretendendo ser exaustiva. Por fim, em diversos iudicia não denominados bonae fidei iudicia (propriamente ditos) nos tempos clássicos, verificar-se-ia a fides bona na mesma medida, fato que seria explicado em razão da inexistência de denominação comum para os iudicia. ${ }^{323}$

As criticas de F. Schulz têm o mérito de destacar o fato de que as fórmulas dos bonue fidei iudicia teriam se desenvolvido gradualmente, não tendo sido concebidas por um único estudioso dentro de um plano amplo e comprecnsivo. ${ }^{324}$

Todavia, não parece ser coerente o desdobramento dessa constatação, apresentado por P. D. Sunn e Francisco Amaral, tendente a considerar o númuro dos juízos de boa-fé, em principio, ilimitado, uma vez que dependeria do modo como os juristas consideram as situações concretas. ${ }^{325}$

Em verdade, mais assentado é reconhecer que os bonae fidei iudicia tutelavam um conjunto determinado - ainda que amplo . de pressupostos fáticos nos quais era possivel empregar o esquema operativo da bona fides. ${ }^{326}$ Estar-se-ia, assim, diante de situações tipificadas, e não de um rol aberto de juízos de boa-fé.

321. Cf. A. M. R. MENE7ES CORdeiro, Da Boa-fé cit. (nola 5 supra), p. 74-75; AlEXANDRE Correia Gatiano Sciascia, Manual de Direito Romano, 2"1 ed., vol. I, São Paulo, Saraiva,1953, p. 103.

322. Cf. Gai 4,62

323. Cf. Classical cit. (nota 243 supra), p. 35.

324. Cf. Classical cit. (nola 243 supra), p. 35.

325. Cr. Buona fede cil. (nota 61 supra), p. 133; e A Boa-fé cit. (nota 8 supra). p. 202.

326. Cf. M. TALAMANCA, La 'bona fides cit. (nota 10 supra), p. 52-53. ('f. tb. cap. IV.2.2 szpra. 
3.6. Fórmula e cláusula oportet ex fide bona.

Como já se viu acima, ${ }^{327}$ os bonae fídei iudicia somente podiam ser invocados no curso de um processo formular, configurando uma categoria particular de juízos de procedimento nos quais se adotava uma fórmula dotada da aposição de uma cláusula especial de boa-fé

Tendo em vista essas informações, deve-se proceder ao exame das particularidades e implicações da fórmula adotada nos juízos de boa-fé. Para tanto, mister que se façam algumas breves considerações de cunho propedêutico acerca da estrutura genérica dos procedimentos adotados no âmbito do processo formular.

A fórmula caracterizava-se como documento escrito que o magistrado entregava, com o acordo das partes, juiz privado eleito para dirimir a controvérsia ${ }^{328}$ Tal documento compunha-se por quatro partes (ou cláusulas), além da nomeação (datio iudicii): intentio, demonstratio, adiudicatio e condemnatio ${ }^{329}$

A intentio pode ser descrita como a parte da fórmula que encerra o direito pretendido pelo demandante, contendo a enunciação da relação jurídica substancial sobre a qual a demanda era fundada. ${ }^{330}$

Nas ações que versavam sobre relações obrigacionais, a intentio poderia ser certa ou incerta, conforme revelasse uma dúvida referente a objeto determinado ou indeterminado (incertum). Na segunda hipótese, a intentio requeria uma prévia demonstratio, cláusula pela qual se especificava o fato constitutivo do direito alegado pelo autor. $^{331}$

A cláusula da aiudicatio, por seu turno, permitia ao juiz adjudicar determinada coisa a um dos litigantes, sendo típica das ações divisórias, dentre outras. $^{332}$

327. CI. cap. IV. 3.1 supra.

328. Cf. M. TALAMANCA, La repubblica cit. (nota 255 supra), p. I 66. 89.

329. Cf. José RogérIo CRUZ E T UCCI - LuIZ CARLOS DE AZEVEDO, Lições cit. (nola 255 supra), p.

330. Cf. A. D'ORS, Elementos cit. (nola 250 supra), p. 59; JOSÉ ROGÉRIO CRUZ E T UCCI-LUIZ CARLOS DE A7.FVEDO, Lições rit. (nota 255 supra), p. 90.

331. Cf. A. D’OrS, Elementos cil. (nota 250 supra), p. 59; JOSÉ ROGÉRIO CRUZ E TUCCI- LUIZ CARLOS DE AZEVEDO, Lições cit. (nota 255 supra), p. 91-92. 93.

332. Cf. José Rogério CruZ e TuCCI - Lutz CAR Los de AZEvedo, Lições cit. (nota 255 supra). p. 
Já a condemnatio seria a conclusão lógica da fórmula, cláusula na qual se confere ao juiz o poder para absolver ou condenar o réu, tendo por objeto uma quantia pecuniária (determinada ou incerta). ${ }^{333}$

Dentre os juízos cujas fórmulas continham uma demonstratio, segundo a qual o juiz tinha de averiguar "tudo o que" (quidquid) o sujeito passivo devia por determinada causa incerta, ${ }^{334}$ destacavam-se justamente os bonae fidei iudicia. em que se fazia referência a uma demanda fundada na fides bona (oportere ex fide bona). ${ }^{335}$

A possibilidade de poder contemplar objetos incertos permitia que fossem consideradas, nos juízos de boa-fé, não apenas obrigações de dar como objeto quantia certa de dinheiro ou coisa determinada. mas genericamente quaisquer obrigações de dar ou fazer. ${ }^{336}$

A fórmula dos bonae fidei iudicia, portanto. caracterizava-se por uma estrutura particular: a condemnatio não era precedida pela simples intentio. mas por uma cópia da cláusula formada pela demonstratio seguida pela intentio.

Essa particularidade comportava uma divisão, em duas partes, da relação jurídica invocada pelo autor: em uma parte a fonte de tal relação e, em outra, a obrigação que dela derivou. A fonte constava enunciada na demonstratio como objeto de juízo. enquanto na intentio, que enunciava a relação jurídica invocada pelo autor a 93.

333. Cf. José Rogério Crul e TuCCI - Luiz CAR los de AZEvedo, Lições cit. (nota 255 supra), p.

334. De fato, estar-se-ia diante de uma fórmula incerta, não apenas em relação ao objeto mas também no que concerne à causa da obrigação (aditamento ex fide bona), conforme afirma M. KASER. Das römisches cit. (nola 61 supra), p. 205.

335. Cf. A. D'ORS. Elementos cit. (nota 250 supra), p. 59; B. BIONDI, Contratu cit (nota 309 supra). p. 238: A. Gl arINO, Diritlo privalo romano. $12^{\mathrm{a}} \mathrm{ed}$., Napoli, Jovene, 2001, p .192; M. KASI R, Das römisches cit. (nota 61 supra), p. 205; e A. S. JUS TO. Direito Privado cit. (nota 254 supra), p. 246. Importa ressaltar que as ações de boa-fé não eram as únicas a sancionar o incertum, como demonstra a criação (aproximadamente no mesmo período histórico) da actio ex stipulatio incerti, a qual era uma ação de direito estrito. De qualquer forma, parece correto afirmar que as ações de boa-fé constituiram o protótipo das açòes incertas. as quais foram concebidas tomando por base o modelo das primeiras. Cf. P. D. SENN, Buona fede cit. (notu 61 supra), p. 132.

336. Cf. P. D. SENN, Buona fede cit. (nola 61 supra).p. 132. Conforme observa Fravcisco AMARAI, A Boa-fé cit. (nota 8 supru). p. 203, em relação às prestações referentes a obrigações de fazer, era necessário levar em conta os elementos requeridos pela boa-fé (conhecimento e observância das regras técnicas, diligência profissional e respeito aos pactos especiais estipulados pelas partes). 
seu próprio favor. os deveres do réu cram indicados de seguinte forma: quidquid ob eam rem $\mathrm{Nm} \mathrm{Nm}$ Ao dare facere oportet ex fide bona. ${ }^{337}$

Para resolver um problema concreto, este modelo abstrato deve ser adaptado às circunstâncias. Assim. V. Arangio-Ruiz cita a hipótese de um vendedor grego que desejava ir a juízo contra um comprador romano. Facultava-se ao refurido vendedor a preparação de um plano escrito, a ser apresentado ao juiz, no qual constava a recordação da premissa da celebração da compra e venda, bem como a solicitação para a condenação da contraparte ao quidquid dare facere oportet ex fide bona. ${ }^{338}$

De modo a ilustrar a prática do procedimento em tela. relevante transcrever outro exemplo, desta feita apontado F Schulz. concernente ao iudicium venditi, tutela própria para o vendedor de uma coisa reclamar o preço devido: Quod Aulus Agerius Numerio Negidio, quo de agitur, vendidit, quidquid paret ob eam rem Numerium Negidium dare facere oportere ex fide bona, eius iudex Numerium Vegidium Aulo Agerio condemnatio, si non paret absolvito. ${ }^{339}$

É a cláusula ex fide bona $a^{340}$ que torna o iudicium venditi um juízo de boafé. Os termos "quidquid paret ob eam rem Numerium Negidium dare facere oportere ex fide hona" contêm a intentio incerta, com base na qual o juiz está autorizado a fixar a soma devida ao autor conforme as exigências da fides bona, soma esta que poderá ser maior ou menor do que o preço estipulado. Maior. por exemplo, se o demandado incorreu em mora e por este motivo passou a dever juros; menor, por exemplo, se as partes tiverem acordado que o preço deve ser pago em parcelas sucessivas, das quais apenas a primeira tenha vencido. ${ }^{341}$

337. "Tudo o que o réu Sicrano deve dar ou fazer, segundo a fides bona". Cf. P.D. SENN, Buona fede cit. (nota 61 supra), p. 131.

338. Cf. Storia cit. (nota 266 supra), p. 145.

339. Se restar comprovado que Aulo Augério (vendedor) vendeu a coisa, o juiz deve condenar Numério Negidio (comprador) a dar e fazer conforme a boa-fé; se não restar demonstrado, deve absolvêlo" Eius é um genitivo relacional, significando "a teor do que haja sido dito na parte precedente da fórmula o juiz deve fazer uma valoração em dinheiro e condenar o demandado a pagar uma soma fixa" Cf. Classical cit. (nota 243 supra), p. 34. Conforme observa M. 'ГALAMANCA, La repubblica cit. (nota 255 supra), p. 167. Aulo Augério e Numério Negidio eram tomados como nomes típicos do autor e do réu.

340. Por regra geral, a formula venditi contém a adição da ( $x$ fide bona àintentio. Excepcionalmente. a redação pode ser diversa (como na actio fiduciae e na actio rei uxoriae), em razão da multiplicidade de sujeitos responsáveis. Cf. F. SCHULZ, Classical cit. (nota 243 supra). p. 34.

341. Cf. F. Schul.7, Classical cit. (nota 243 supra), p. 34. 
A cláusula "Quod Aulus Agerius Numerio Negidio fundum Cornelianum, quo de agitur, vendidit". por sua ver, constitui a demonstratio, necessária em função da já referida intentio incerta. ${ }^{342}$

Conforme se pôde notar quando da análise do exemplo acima apontado, nos juízos de boa-fé as obrigações vinham deduzidas segundo o esquema quidquid dare facere oportet ex fide bona, o qual concedia ao juiz o poder de valorar a pretensão conforme os ditames da fides bona.

A aposição do referido esquema na intentio atribuia ao juiz uma ampla margem de valoração discricionária, não encontrada nos iudiciae stricti iuris. Com base nessa margım, permitia-se ao juiz estabelecer. a seu critério, tudo aquilo que o réu devesse prestar ao autor com base na fides bona, devendo proceder a uma interpretação consoante o conjunto de circunstâncias do caso concreto, e não apenas de acordo com a letra do pacto ou da lei. ${ }^{343}$ Transformava-se assim, como alega A. Justo, o incertum em cerlum. $^{344}$

De fato, conforme aponta V. Arangio-Ruiz, o oportet ex fide bona trazia consigo uma particular flexibilidade, uma atitude de adequação às mais sutis matizes da vontade das partes, bem como às mais diversas exigências da consciência juridica. ${ }^{345}$

Nesse contexto, A. Guarino obscrva que a tarefa do juiz não deveria restringir-sc apenas a reconhecer a existência c o valor da obligatio declarada pelo autor. Fundamental seria também proceder ao exame de todas as razões expostas pclo autor ¿ de todas as justificativas do demandado para estabelecer se, e em que medida, umas ou outras se distanciassem das exigências da fides bona. ${ }^{346}$

342. Cf. F. SCHulz, Classical cit. (nota 243 supra), p. 34.

343. Cf. A. Guarino, Diritlo cit. (nota 336 supra), p. 192; P. D. SENN. Buona fede cit. (nota 61 supra), p. 131; A. D'ORS, Elementos cit. (nota 250 supra), p. 60; 233: B. BIONDI, Contrato cit. (nota 309 supra), p. 238; M. KASER, Das römisches cit. (nota 6l supra), p. 200; e A. M. R. MENEZESCORDEIRO,Da Boa-fé cit. (nola 5 supra). p. 82. A amplitude e delicadeza dos poderes atribuidos ao juiz de um bonae fidei iudicium, como aponta V. ARANGIO-RUIZ. Istituzioni cit. (nota 245 supra), p. 299. já teriam sido profundamente sentidas à época de Cícero.

344. Cf. A. S. Justo, Direito Privado cit. (nota 254 supra), p. 245.

345. C.f. Istituzioni cit. (nola 245 supra), p. 298. Para o autor. o oportel ex fidt bona pode ser visto como um fator de primeira ordem na evolução do sistema contratual romano.

346. Cf. Diritto privalo cit. (nota 336 supra), p. 192-193. No mesmo sentido, Francisco Amaral, A Boa-fé cit. (nota 8 supra). p. 202. 
Da mesma forma, seria imprescindivel o exame da lealdade, honorabilidade e fidelidade à palavra. Assim, afirma-se que o juiz deve atender potius id quodactum, quam id quod dictum sit ("mais daquilo que se quis fazer do que daquilo que foi dito"); cumpre-lhe apreciar o comportamento das partes no momento do contrato ou durante a execução deste, bem como no momento da propositura da uctio. $^{347}$

Nesse diapasão, o conteúdo e os efeitos do próprio contrato não dependeriam apenas da declaração das partes, mas também da naturcza do negócio em seu complexo. Ademais, não seria suficiente considerar somente o contrato em si mesmo, uma vez que os deveres do réu no momento da sentença dependiam também do comportamento adotado pelas partes após a conclusão do contrato, e mesmo durante o curso do processo. ${ }^{348}$

Em relação ao exame das nuances do caso concreto. L. Vacca aponta nas fontes exemplo ilustrativo, em que Celso negava ao vendedor a possibilidade de valerse da actio venditi para o pagamento do preço, tendo o comprador adquirido a disponibilidade do bem ex alia causa, e não ex causa emptionis. ${ }^{349}$ Neste caso, tendo em vista que se está diante de um contrato sinalagmático. tutelado por iudicium bonue fidei, a boa-fé permite condicionar a condenação e a exigibilidade de uma prestação à circunstância de a contraprestação no sentido de atribuição patrimonial dependente da causa do contrato - já ter sido extinta ou permanecer exigível. ${ }^{350}$

A operatividade do sinalagma, de acordo com L. Vacca. teria papel fundamental no desenvolvimento da relação contratual, a qual, sendo tutelada por um iudicium bonae fidei, impunha que se mantivesse o equilíbrio entre as prestações. ${ }^{351}$

Cabe ressaltar que a margem de discricionariedade conferida ao juiz não deve ser confundida com uma pretensa arbitrariedade (liberum officium), que lhe

347. Cf. A. S. Justo, Direito Privado cit. (nota 254 supra), p. 246.

348. Dessa forma, por exemplo. o atraso do adquirente no pagamento do preşo assume um significado completamente diverso se o vendedor adimpliu pontualmınte a sua obrigação de consignar o objeto vendido ou se, ao contrário, está em mora. Cf. P. D. SENN, Buona fede cit. (nota 6l supra).p. 132: e Francisco Amaral, A Boa-fé cit. (nuta 8 supra), 202.

349. Cf. Pomp. 11. ad Sab. D. 21, 2, 29.

350. Ct. Buona fede e sinallagma contrattualc' in Il ruolo della buona fede oggetiva nell 'esperienza giuridica storica e contemporanea, vol. IV. Luigi Garofalo (org.). Padova, CEDAM, 2003, p. 350.

351. Cf. Buona fede cit. (nota 351 supra), p. 350. 
atribuiria uma espécie de poder ilimitado para decidir o que pensasse ser conveniente nas demandas. Tratava-se, apenas, de atribuir ao juiz maior liberdade de movimentos, alargando o seu officium, de modo a dispor de uma bitola especialmente lata para decidir. $^{352}$

Com efeito, de acordo com F Schulz, os juristas clássicos desenvolveram um conjunto importante de regras voltadas à interpretação das fórmulas nos bonae fidei iudicia, criando pautas de conduta para os juizes, os quais, em geral, adotavam a doutrina jurídica estabelecida. ${ }^{353}$ Ademais, os próprios ditames da bona fides atuavam como margem de limitação à conduta do iudex, ${ }^{354}$ uma vez que poderiam ser considerados, ao menos a partir da época republicana, como normas de aplicação cogente. $^{355}$

Nesse passo, relevante a constatação de $\mathrm{M}$. Bretone acerca da relação entre a fides e a liberdade do magistrado para a apreciação das circunstâncias concretas nos julgamentos. O poder conferido aos magistrados permitia-lhes, com base no exame das particularidades do caso concreto, conceder (com um decreto) tutela em situações não disciplinadas no edito, arbitrariedade conciliável com o uso correto da iurisdictio. O uso desta, todavia, nem sempre cra correto: as violações eram sempre possíveis, e até mesmo freqüentes. Até o advento, em 67 a.C., de legislação estabelecendo a obrigação de os pretores respeitaram seus éditos, apenas a fides e a dignitas vinculavam os magistrados à observância dos éditos. ${ }^{350}$

De qualquer modo, esta sistemática processual permitia ao juiz chegar a uma conclusão exatamente comensurada, não apenas às injustiças, mas também às razões do réu. ${ }^{357}$ Como resultado, a condenação poderia recair em uma ou outra parte. $^{35 x}$

O iudex, em vez de ater-se a formalismos escritos, tinha por função nos bonae fidei iudicia, através de certos expedientes, descer até a substância das questões.

352. Cf. A. M. R. MfNezes CORdeiro, Da Boa-fé cit. (nota 5 supra), p. 82.

353. Cf. Classical cit. (nota 243 supra), p. 35.

354. Cf. A. CARCATERra. Ancora cit. (nota 198 supra), p. 68.

355. Cf. M. TALAMANCA, La 'bona fides cit. (nota 10 supra), p. 43.

356. Cr. Storia cit. (nola 63 supra), p. 104.

357. Cf. A. GuARINO, Diritto privato cit. (nota 336 supra), p. 193.

358. Cf. V. ARANGIO-RUIZ, Istituzioni cit. (nola 245 supra), p. 299. 
Assim, não bastava uma composição meramente formal dos litígios: procurava-se uma solução verdadeiramente material. ${ }^{359}$

$\mathrm{Na}$ sentença, baseada em circunstâncias concretas e específicas, manifestava-se a atividade criativa do juiz, que em muitos casos estabelecia para as partes uma norma sem precedentes no ordenamento jurídico romano. Esta norma seria particular, mas, através da reprodução em sentenças, chegar-se-ia a uma norma de cunho geral. ${ }^{360}$

P. Voci, para ilustrar esse desenvolvimento, adota como exemplo, a seguir transcrito, uma relação juridica na qual haveria fundamento para compensação de créditos e débitos dos mesmos sujeitos. Suponha-se que, ao fim da tutela, o expupilo exerce contra o tutor a actio tutelae. Examinando esta ação, o juiz determina que o ex-tutor deve ao ex-pupilo 100 sestércios, bem como reconhece que o primeiro gastou 20 sestércios de seu próprio bolso em beneficio do administrado. Tendo em vista que se trata de um iudicium bona fides, não se admitiria que o autor exigisse seu crédito sem que à outra parte não fosse facultado proceder do mesmo modo, o que fundamentaria uma sentença determinando a compensação. ${ }^{361}$

Acredita P. Voci que o primeiro juiz que reconheceu a compensação estabeleceu um efeito específico do critério geral da fides bona, e criou um precedente que, seguido pelos juizes sucessivos, conduziu à criação de uma norma válida para todos os juízos de boa-fé. ${ }^{362}$

Os precedentes criados pelos juizes somavam-se aos preexistentes, fazendo com que, de forma gradual, diversas normas aptas a estabelecer efeitos práticos da cláusula oportet ex fide bona estivesse implícitas nos bonae fidei iudicia. ${ }^{363}$

Dessa forma, impera apontar as principais normas de apreciação judicial relacionadas à referida cláusula, ${ }^{364}$ a qual, como se infere do exposto, era dotada de

359. Cf. A. M. R. Menfzes Cordeiro, Da Boa-fé cit. (nota 5 supra), p. 89.

360. Cf. P. VocI, Manuale cil. (nota 246 supra), p. II2.

361. Cf. Munuale cit. (nota 246 supra), p. 113.

362. Cf. Manuale cit. (nota 246 supra), p. 113.

363. Cf. A. M. R. MEnezes Cordeiro, Da Boa-fé cit. (nola 5 supra), p. 100.

364. Em verdade, os fatores que o juiz pode e deve examinar variam em cada caso, razão pela qual não podem ser exaustivamente enumerados. Cf. M. KASER, Das römisches cit. (nota 6I supra), p. 201. 
amplas conseqüências práticas na composição do litígio, devendo ser consideradas pelo julgador ao fim da sentença. ${ }^{365}$

Primeiramente, as ações de boa-fé permitiriam ao juiz considerar as obrigações reciprocas entre as partes litigantes e avaliar eventuais contra-créditos (nascidos ex eadem causa). Assim, seria possível fixar a condenação do demandado de modo a compensar previamente o que este poderia exigir ao demandante em virtude daquela mesma relação obrigacional (compensatio ex fide bona). ${ }^{366}$

Nesse passo, pode-se afirmar que os bonae fidei iudicia transpuseram a incipiência da compensação no rígido sistema processual romano. reconhecendo ao juiz a possibilidade de operá-la, desde que reunidas as condições necessárias. ${ }^{367}$

Em segundo lugar. deve-se atentar à questão da reciprocidade. uma vez que os bonae fídei iudicia implicavam ações correspondentes. Dessa forma, a iniciativa processual poderia ser tomada por qualquer dos sujeitos da relação obrigacional correspondente. $^{368}$

Com efeito, nas situações jurídicas que lhes caíssem na alçada, as partes dispunham sempre, cada uma, da sua ação de sinal contrário. Em alguns casos, tais ações tinham nomina próprios: actio empti e actio venditi; actio lacti e actio conducti. Nos outros, falava-se apenas, de modo genćrico, em actio contraria. ${ }^{369}$

Ademais, deveriam ser apreciados eventuais pactos acessórios não formais (pacta adiecta) celebrados pelas partes, os quais poderiam ter influenciado a existência e a extensão da obrigação. Em virtude do fato de tais pactos terem o condão de aumentar, diminuir ou tornar ineficaz a obrigação, eles eram valorados como conteúdo do contrato. apreciados na ação contratual sempre que tivessem sido

365. Cf. A. Guarino, Diritto privato cit. (nota 336 supra), p. 193,

366. Cf. A. D'ORS, Elementos cit. (nota 250 supra), p. 233: A. GUARINO, Diritto privato cit. (nota 336 supra), p. 193; M. KASER, Das römisches cit. (nota 61 supra), p. 201; B. BIONDI, Contrato cit. (nota 309 supra), p. 239; e G. Grosso, Buona fede cil. (nota 74 supra), p. 663.

367. De fato, antes do advento dos bonae fidei iudicia, a compensação representava dissonância em relação aos alicerces do sistema processual vigente, uma vez que implicaria a apreciação de elementos estranhos ao pedido e à causa de pedir. Cf. Ulp. $29 \mathrm{ad} \mathrm{ed.} \mathrm{D.} \mathrm{16,} \mathrm{1,} \mathrm{2.} \mathrm{1;} \mathrm{Gai.} \mathrm{4,} \mathrm{63.} \mathrm{Fm} \mathrm{relação} \mathrm{ao} \mathrm{tema,}$ cl. os comentários de A. M. R. MEnezes Cordeiro, Da Boa-fé cit. (nota 5 supra), p. 88.

368. Cf. A. M. R. MENEzes CORDEIRO, Da Boa-fé cit. (nola 5 supra), p. 88: e A. D'ORs, Elemumtos cit. (nota 250 supra), p. 234.

369. A uniformização geral das referidas ações nos bonae fidei iudicia é justinianéia. C.f. A. M. R. Menezes Cordetro, Da Boa-fé cit. (nota 5 supra), p. 88. 
celebrados a par e passo do contrato principal (pactu adiecta in continendi) ou depois da conclusão deste (pacta adiecta ex intervallo). ${ }^{370}$

O regime dos pacta adiecta para os contratos dos quais deriva um iudicium bonae fidei, conforme nota B. Biondi, é substancialmente diverso daquele dos demais juizos. Havendo oportere ex fide bona, supera-se o tradicional principio que ex nudo pacto actio non nascitur, em face da inerência dos pacta. ${ }^{371}$ Em outras palavras, o juiz deveria, sempre que se deparasse com um oportet ex fide bona, indagar acerca da exceptio pacti. ${ }^{372}$

Também as eventuais prestações acessórias (como juros. frutos, etc.) ${ }^{373} \mathrm{e}$ a adjudicação de interesses não pactuados eram considerados inerentes aos bonae fidei iudicia, enquanto nos outros juízos era necessária a aposição de uma stipulatio para tanto. ${ }^{374}$

Esta consideração tem particular relevo para a discussão do problema da evolução histórica da responsabilidade contratual. O início da consideração da culpa (como negligência) deu-se nos contratos dos quais derivava um iudicium bonae fidei, no qual a conduta do devedor em relação ao adimplemento da obrigação deveria ser submetida a uma valoração mais profunda: como eram contrários à bona fides quaisquer comportamentos menos que corretos, de forma semelhante não poderia escapar a negligência do devedor em relação ao adimplemento da obrigação. ${ }^{375}$

Ademais, a vontade efetiva e real, acima da exteriorização, é certamente dotada de maior consideração quando se trata de iudicia bonae fidei. A questão o erro, portanto, projeta-se de modo mais preciso. ${ }^{376}$

370. Cf. A. S. Justo, Direito Privado cit. (nola 254 supra), p. 246; A. GUARINo, Dirtito prinedo cit. (nota 336 supra), p. 193; e M. KASER, Das römisches cit. (nota 61 supra), p. 201. G GRosso, Buona fede cit. (nota 74 supra), p. 663, por sua vez, não admite a inerência dos pacta adiecta ex intervallo.

371. Cf. Contrato cit. (nota 309 supra), p. 239.

372. Cf. A. M. R. Menezts Curdeiro, Da Boa-fé cit. (nola 5 supra), p. 87.

373. Cf. A. GUARINo, Dirilto privalo cit. (nola 336 supra), p. 193; e M. KASER, Das römisches cit. (nota 6I supra), p. 201.

374. Cf. A. Guarino, Dirillo privato cit. (nota 336 supra), p. 193; M. KASER, Das römisches cit. (nota 61 supra). p. 201; e B. BIONDI. Contrato cit. (nota 309 supra). p. 240.

375. Cf. B. BIONDI, Contrato cit. (nota 309 supra), p. 240.

376. Cf. B. BIONDI, Contrato cit. (nola 309 supra), p. 240. 
Outrossim, os artificios desleais exercitados por uma parte em face da outra - como o dolo (dolus malus), a coação ilícita (vis metusvei) e a subjugação a uma situação de temor (metus). ${ }^{377}$

Tendo em vista que a bona fides por si exclui qualquer comportamento incorreto (não apenas em relação ao adimplemento da prestação, mas também à própria conclusão do contrato), quando uma parte queixava-se de uma das referidas condutas do adversário, as quais tram desconformes com a bona fides, não se exige a oposição formal de uma exceção (exceptio doli). ${ }^{378}$

De fato, quando se tratava de contrato que dava lugar a um iudicium ex fide bona, caso um dos contraentes tenha sofrido violência ou sido enganado, nulo ipso iure seria o contrato, devido ao fato de que o oportere ex fide bona exige serem a violência e o dolo levados em consideração. Com efeito, não poderia o juiz consentir com a existência de um oportere ex fide bona eivado de tais vícios. ${ }^{379}$

Assim, enquanto como regra geral toda e qualquer queixa de condutas desleais das partes devesse ser expressamente alegada em juízo e, assim, levada ao conhecimento do magistrado e inserida na fórmula como exceptio doli, rinha-se como inerentes $^{380}$ aos bonae fidei iudicia tal exceção. ${ }^{381}$

377. Cf. A. GUaRINO, Diritto privato cit. (nota 336 supra), p. 193; M. KASER, Das römisches cit (nota 61 supra), p. 201 ; e B. BIONDI, Contrato cit. (nola 309 supra), p. 239.

378. Cf. A. D`Ors, Elementos cit. (nola 250 supra), p. 233; e A. M. R MENEZESCORDERO, Da Boufé cit. (nota 5 supra), p. 87 ss. Nesse sentido, B. BIONDI, Contrato cit. (nota 309 supra), p. 239, afuma que o juiz. em virtude do próprio oportere ex fide bona, é investido do conhecimento do dolo da parte, uma vez que, como diziam os romanos, fides bona contraria est fraudi et dolo. O oportere ex fide bona a a conseqüente inerência da exceptio doli importam comportamento segundo a boa-fé por parte de ambos os contraentes. Estas conclusões seriam baseadas na exegese de Paul. 32 ad. ed., D. 17, 2, 3, 3.

379. Cf. B. BIONDI, Contrato cit. (nota 309 supra), p. 239.

380. A. M. R. MENezes Cordeiro, Da Boa-fé cil. (nota 5 supra), p. 87, nota que a expressão "inerência das exceçōes", largamente acolhida nas fontes, não é, em rigor, correta. Conforme observa o autor. nos bonae fidei iudicia o juiz, perante o oportet ex fide bona da fórmula pretoriana, licava automaticamente adstrito a conhecer da malícia das partes, de pactos adjacentes e de uutros fatores prejudiciais. Seria preferivil, assim. falar em "inutilidade das exceçōes" nos bonae fidei iudicia.

381. Cf. V. ARANGIO-RUIZ, Istituzioni cit. (nota 245 supra). p. 299; AleXANDre CorreiaGateT ano SCIASCIA, Manual cit. (nola 322 supra), p. 102-103; e A. S. JUSTO, Direilo Privado cit. (nota 254 supru), p. 246. 
Por fim, a infrigência de deveres acessórios que a relação obrigacional impõe às partes (em especial, deveres de proteção e fidelidade), legitimavam a exigência de indenização. ${ }^{382}$

Em síntese, o critério da boa-fé permitia ao juiz estimar com maior flexibilidade a responsabilidade do demandado e o interesse do demandante, avaliando as circunstâncias individuais do caso concreto. ${ }^{383}$

3.8. Caracterização como conjunto de regras jurídicas.

Outra questão relacionada ao exame da fórmula no âmbito dos bonae fidei iudicia é aquela concernente à possibilidade de a fides bona ser compreendida como fonte das obrigações.

Para responder a tal questão, é necessário notar que na fórmula inseriamse regras e princípios que, geralmente. justificavam o surgimento das obrigações e que, por este mesmo motivo, faziam parte do ordenamento jurídico romano. Este conjunto de regras e princípios consistiria, precisamente, no sistema da fides bona. ${ }^{384}$

Uma análise atenta da fórmula dos bonae fidei iudicia, portanto, permitiria concluir-se que a fides bona não é fonte de obrigações, mas um conjunto de regras jurídicas que se referem ao regime jurídico das obrigações. De fato. menciona-se na demonstratio a situação concreta da qual deriva a obrigação. mas a origem e o conteúdo desta são regulados pela fides bona, presente na intentio. ${ }^{385}$

382. M. KASER, Das römisches cit. (nota 61 supra), p. 201.

383. Cf. A. D’ORS, Elementos cit. (nota 250 supra). p. 234.

384. Cf. P. D. SENN, Buona fede cit. (nola 61 supra), p. 132; e FRANCISCO AMARAL, A Boa-féc cut. (nota 8 supra), p. 202.

385. Cf. P. D. SENN, Buona fede cit. (nola 61 supra), p. 132; e Francisco AMARAL, A Boa-fécit. (nota 8 supra), p. 202. 
3.9. Relação com os contratos consensuais.

Nos contratos consensuais, a relação obrigatória é sustentada pela fides bona, que determina e justifica a tutela jurisdicional. ${ }^{386}$

A menção à boa-lé na intentio da fórmula dos bonae ficlei iudicia permitia também compreender o caráter bilateral da relação obrigacional em causa, bem como ter em conta a interdependência das obrigações das partes, novidade trazida por tais juizos). É nesse contexto, portanto, que o regime da fides bona gerou aquele dos contratos consensuais, consoante observa P. D. Senn. ${ }^{387}$

$\mathrm{O}$ estrito vínculo entre as partes esclarece a notável flexibilidade dos contratos consensuais, a qual é a razão a impossibilitar uma descrição genérica destes contratos, a não ser pela estrutura de base comum que eles apresentam. De fato, se os juristas romanos imaginaram formas contratuais muito amplas, eles estabeleceram os regimes destas por meio de uma análise casuística e conduzida com base em diversas espécies de relações jurídicas. ${ }^{388}$

Dessa forma, tem-se que os juristas romanos claboraram um regime jurídico próprio para cada espécie de relação. sobre a base do modelo de "classe contratual que se comporta segundo a regra da boa-fé" É precisamente assim que as vastas categorias contratuais romanas deram origem à maior parte dos diversos tipos contratuais modernos. $^{384}$

4. Bona fides como princípio de boa-fé objetiva do Direito romano.

O Direito romano, reconhecido como um Direito de principios e de juristas, era visto sob a perspectiva dos casos concretos. A casuística jurídica romana ${ }^{390}$ apresenta a natureza de raciocínio que partia da realidade natural e concreta, com

386. Cf. M. BRETONE, Storia cit. (nota 63 supra). p. 102.

387. Cf. Buona fede cit. (nota 61 supra), p. 132.

388. Cf. Francisco Amaral. A Boa-fé cit. (nota \& supra), 203.

389. Cl. P. D. SEnN, Buona fede cir. (nota 6I supra), p. 132; e Francisco Amaral, A Boa-fécit. (nota 8 supra), p. 203.

390. Consoante ressalta Francisco Amaral. A Boa-fé cit. (nota 8 supra). p. 199, deve-se preferir "casuística juridica romana" a "problemática romana" uma vez que o pensamento jurídico romano ter-seia orientado pela razão prática, e não pela razão teórica do pensamento axiomático-dedutivo. 
excepcional vocação para extrair princípios e construções jurídicas afirmados como universais. $^{391}$

Assim, pode-se apontar como grande mérito dos juristas romanos a procura por princípios e soluções para problemas sociais e casos concretos. atendendo às exigências da vida e ao seu sentido de justiça. ${ }^{392}$

Com efeito, o sistema jurídico romano era, como aponta $M$. TALAMANCA, um sistema aberto. Dessa forma, abrangia valores tidos como presentes em medida mais ou menos incisiva, segundo o arranjo social, político-econômico e cultural da comunidade - e juridicizados pelos juristas e magistrados, sem a dependência de normatização escrita. ${ }^{393}$

Dentre esses valores presentes no seio da comunidade e juridicizados para possibilitar a solução de problemas sociais e casos concretos, atuando de forma difusa, sem normatização escrita, merece destaque justamente a bona fides. ${ }^{394}$

Essa noção jurídica possibilitava a mesuração de manifestações de regularidade nas condutas, de modo a tornar previsíveis as soluções para conflitos futuros. De fato, a hona fides permitia que se tratasse o igual por igual e o diferente de modo diferente, de acordo com a medida da variação, almejando um equilíbrio nas relações jurídicas, capaz de suscitar consenso na comunidade. ${ }^{395}$

Assim, a bona fides atuava como critério de valoração das circunstâncias do caso concreto, impondo às partes da relação jurídica uma série de deveres inerentes ao respeito ao vínculo assumido. Estes deveres baseavam-se no padrão de comportamento com lealdade e retidão, esperado do homem médio romano 396

Por meio de tal expediente técnico, possibilitava-se ao juiz decidir certas causas considerando não apenas a verificação eventual do fato central (apresentado como causa petendi), mas também outros fatos conectados com o litígio. O iudex,

391. ('. CaIO Mário da SIIVA PEREIRA, Boa Fé cit. (nota 9 supra), p. 486; e Franciscoamaral. A Boa-fé cit. (nota 8 supra), p. 199.

392. Cf. Francisco Amaral, A Boa-fé cil. (nota 8 supra), p. 199.

393. Em oposição, os sistemas fechados, como os ordenamentos jurídicos modernos da familia romano-germânica, fundam-se primordialmente na prevalência de fontes normativas exprussas, sobretudo na forma de códigos. Cf. La 'bona fides' cit. (nota 10 supra), p. 21-26.

394. Cf. Francisco Amaral, a Boa-fé cit. (nota 8 supra), p. 199.

395. Cf. A. M. R. MENEZES CORdeiro, Da Boa-fé cit. (nota 5 supra). p. 18.

396. Cf. cap. IV.2.2 supra. 
assim, procurava uma solução verdadeiramente material para a controvérsia, examinando o conjunto de razões expostas pelo autor e as justificativas do réu, para determinar sc as partes haviam observado a bona fides em sua relação. ${ }^{397}$

Dessa forma, a intepretação dos negócios juridicos passava a exigir a análise da efetiva conduta das partes em todos os momentos da relação entre elas estabelecida. ${ }^{398}$

Nesse cenário, parece correto reconhecer que a bona fides configurava verdadeiro principio de boa-fé objetiva do Direito romano, exigindo das partes comportamento conforme padrões de retidão esperados do bonus paterfamilias, e atuando como cânone interpretativo dos negócios jurídicos. ${ }^{399}$

Assim, a concreta atuação do princípio da boa-fé objetiva moderno seria matéria já constante do Direito romano, ${ }^{400}$ caracterizando-se como criação original deste. $^{401}$

5. Difusão e conseqüente subjetivação da bona fides.

Parte da doutrina romanística, com destaque para $\mathrm{A}$. Montel e $\mathrm{P}$ Bonfante, reconhecem que há diferenças superficiais na noção de boa-fé romana - a qual se caracteriza por ser bastante rigorosa em algumas relações (por exemplo, os contratos), enquanto em outros institutos (como na usucapião) surge mais branda sem, contudo, admitir a bipartição entre a boa-fé das relações de Direito Real e a das relações obrigacionais. ${ }^{402}$

Para esta corrente, alguns elementos, a primeira vista, poderiam lembrar um contraste com a unidade da noção, o qual, contudo, sria desmentido por um exame

397. Cf. cap. IV.3.6 supra.

398. Cf. cap. IV.3.6 supra.

399. Cf. Francisco AmARAL, A Boa-fé cit. (nota 8 supra). p. 200: 204:

400. C.f. A. TRISCIUOGLIO, Bona fides e locazioni pubbliche nelle opinion's di Ulpiano in Il nuolo della buona fede oggetiva nell 'esperienza giuridica storica e contemporanea, vol. IV, Luigi Garofalo (org.), Padova, CEDAM, 2003, p. 312; P. BONFANTE, Essenza cit. (nola 6 supra).p. 719; A. QuARINo, Diritto cit. (nola 336 supra), p. 192-193; e FRANCISCO AMARAL. A Boa-fé cit. (nota 8 supra), p. 196.

401. Cf. P Vocl, Manuale cit. (nola 246 supra), p. 113.

402. Cf. Buona fede cit. (nota 106 supra), p. 602; e Essenza cit. (nota 6 supra), p. 728. 
atento do problema. Dessa forma. a boa-fé romana. em todas as situações, seria formalmente idêntica, consistindo na efetiva intenção de não violar o ordenamento jurídico. Pretensos indícios da bipartição da noção, na visão de A. Montel. significariam apenas que nem sempre a boa-fé era, por si, merecedora de tutela jurídica, e que a variedade das relações deve, necessariamente, ser apreciada. ${ }^{403}$

Contudo, essa orientação parece não estar bem fundamentada, ignorando as diferenças fundamentais existentes entre a boa-fí romana tomada nas acepções objetiva (pauta de conduta nas relações obrigacionais) e subjetiva (estado psicológico do individuo).

Mais do que dois prismas de uma mesma noção, estar-se-ia, em verdade, diante de duas noções diametralmente opostas, incompatíveis entre si ${ }^{404}$ Nesse sentido, P. D. Senn nota que haveria uma certa dificuldade para compreender como os juristas conservaram a mesma terminologia. ${ }^{405}$

Com efeito, a boa-fé romana constitui, através dos iudiciae aos quais ligou o seu nome, verdadeira norma de boa-fé objetiva. Ela acabaria, todavia, sendo posteriormente utilizada com um significado diverso nas fontes, na seara dos Direitos Reais. Neste campo, o sentido da bona fides seria flagrantemente diferente do dos bonae fidei iudicia. ${ }^{406}$

Desse modo, alím da ampla diferenciação de conteúdo apresentada entre as noções objetiva e subjetiva da bona fides, deve-se apontar que esta última não é contemporânea - e, muito menos, predecessora - da primeira. De fato, consoante afima M. Talamanca, "al livello delle fonti giuridiche, non risultano impieghi di bona fides in senso soggetivo anteriori a yuelli fatti sul piano del significato oggetivo del sintagma" 407

O Direito romano teria, no seu periodo clássico, apresentado a indicação de grandes grupos de situações possessórias típicas bonae fidei (notadamente no campo

403. Cf. Buona fede cit. (nota 106 supra), p. 602.

404. Cr. M. Tal AmanCa, La 'bona fides cit. (nota 10 supra). p. 16.

405. Cf. Buona fede cit. (nota 61 supra), p. 133.

406. Cf. A. M. R. Menezes Cordeiro, Da Boa-fé cit. (nota 5 supra), p. 106; 109.

407. "No âmbito das fontes juridicas, não consta emprego da bona fides em sentido subjetivo anterior áqueles fatos sob o plano do signficado objetivo do sintagma". Cf. La 'bona fides cit. (nota 10 supra), p.
40 . 
do usucapião), nas quais avultava, como grande denominador comum, o estado psicológico do individuo. ${ }^{408}$

A bona fides, nesta acepção, seria um puro estado de espírito, caracterizado pelo desconhecimento da existência de vícios, sem componentes éticos. Traduziria na prática, portanto, a não exigência da excusabilidade do erro, exceto em situações marginais. Aqui, a bona fides não projetaria quaisquer normas jurídicas, caracterizando-se apenas como um elemento fático extrajurídicu. Neste seu papel, a bona fides não comportaria uma ligação direta evidente com a chamada bitola de comportamento do Direito das obrigações. ${ }^{409}$

Conforme se procurará demonstrar a seguir, muito melhor é reconhecer que a boa-fé romana subjetiva teria sido uma criação artificial, resultante de um processo de difusão horizontal ${ }^{410}$ da fides bona.

Desmorunado o sistema formular. justa a tendência do processo extra ordinem transpor ao Direito substancial aquilo que resultava da redação da fórmula. preferindo-se, a partir de então, falar em contractus, em lugar de iudicium bonae fidei. Todavia, no novo Direito ambas estas noções perderam boa parte da precedente importância, em face de uma lei de Constantino. ${ }^{411}$

Nesse cenário, a bona fides perdia seu veículo condutor. qual seja o processo formular, tornando-se uma noção substancial com obstáculos práticos à aplicação aos casos concretos, visto que esta dependia da atuação judicial.

De outra parte, o aperfeiçoamento registrado na usucapião durante o Período Clássico requereu a nominação de uma realidade nova (estado psicológico de ignorância do beneficiário), tomada como requisito de tal instituto. Para este efeito. foi utilizada a bona fides, em um processo de difusão horizontal. ${ }^{412}$

408. Cr. A. M. R. Menezes Cordeiro, Da Boa-fé cit. (nota 5 supra), p. 109; e. M. Talamanch, Lu 'bona fides' cil. (nora 10 supra), p. 16 ss.

409. CF. A. M. R. Menezes Cordeiro, Da Boa-fé cit. (nora 5 supra)., p. 106-109

410. Verifica-se difusāo horizontal quando uma expressão qualificativa de um instituto jurídico concreto passa a designar, também, um instituto diverso. Cf. A. M. R. MENEZESCORDEIRO, Da Boa-fé cit. (nota 5 supra), p. 129.

411. Cf. C. I, 8, 3. Em ralação ao tema. cf. os comentários de B. Biond, Contrato cit. (nota 309 supra), p. 241.

412. Cf. A. M. R. MENEzes Cordeiro, Da Boa-fé cit. (nota 5 supra), p. 129. 
A natureza técnico-jurídica do termo, ressaltada pela sua utilização exclusiva em textos jurídicos, e a não dependência das caracteristicas originais do instituto, indiciariam a probabilidade de tratar-se de que houve uma reforma conduzida pelos jurisprudentes. ${ }^{413}$

Haveria notável vantagem no emprego da noção de bona fidcs à posse: esta noção provocava, tanto no jurista quanto no cidadão comum, a sensação de algo positivo, conveniente, ligado ao bem, suscitando a idéia de aprazibilidade merecedora de proteção. A adequação terminológica seria, portanto, patente ${ }^{414}$

Nesse diapasão, deve-se reconhecer a probabilidade de a bonae fidei possessionis ter surgido como um fenômeno de colonização lingüistica ténica. Profundamente diferente dos bonae fidei iudicia. a referida expressão revelaria, tal como estes, uma formação voluntarística e estudada de noções jurídicas. A transposição teria sido artificial, não havendo mais do que tênues ligações não jurídicas entre as duas utilizações. ${ }^{115}$

Aqui, portanto, teria sido iniciado um processo de difusão horizontal da boa-fé, dentro da ordem juridica, processo este que seria traduzido no emprego da noção em institutos díspares. No caso, a difusão horizontal ganharia intensidade com a introdução posterior da boa-fé em outros institutos, como o casamento e a acessão, sempre com o sentido de elemento psicológico a indicar ignorância de certos vícios. ${ }^{410}$

A difusão horizontal implicaria a perda de conexões da boa-fé com institutos jurídicos que primeiramente a haviam consagrado. Tal processo abriria as portas para a difusão vertical e, posteriormente, à diluição. ${ }^{417}$

413. Cf. A. M. R. MEnezes Cordeiro, Da Boa-fé cit. (nola 5 supra), p. 113.

414. A. M. R. Menezes Cordeiru. Da Boa-fé cit. (nola 5 supra), p. 113, admite que este novo processo de criação jurídica. com recurso à fides, tenharse iniciado na emplio, o que, $\mathrm{cm}$ um fatur suplementar de associação, contribuiria para explicar por que foi escolhida a expressão hona fides i não outra.

415. Cf. A. M. R. Menezes Cordeiro, Da Boa-fé cir. (nota 5 supra), p. 113.

416. Cf. A. M. R. MEnezes Cordeiro. Da Boa-fé cir. (nota 5 supra), p. 113.

417. Diz-se diluida uma noção quando. nos mesmos período histórico e ordem jurídica. seja ela repetidamente utilizada para traduzir situações juridicas distintas, $\mathrm{c}$ ainda. para expressar principios gerais. Assim. pode-se afirmar que uma noção diluida está em toda parte e, quando tomada de furma isolada, pouco quer dizer. C.f. A. M. R. MENEzes CORDEIRo, Da Boa-fé cit. (nota 5 supra).p. 113: 128. 
O pano de fundo desse processo evolutivo são as próprias transformações sofridas pelo Direito romano, agora limitado ao caminho entre os períodos clássico e justinianeu, abrangendo o chamado Direito romano "vulgar" 418

A vulgarização do Direito romano atuou de maneira intensa sobre a bona fides. O recurso à expressão bona fides para traduzir um estado psicológico de ignorância do possuidor, em uma altura na qual o termo - por meio dos bonae fidei iudicia, já tinha um sentido técnico consagrado, seria um claro sinal de confusão. Implicaria, em pleno Periodo Clássico, um estilo simplista, o qual, com base em conexões pouco mais do que psicológicas, permitiria um emprego acrítico da terminologia científica, acarretando a vulgarização da bona fides. ${ }^{419}$

A referida vulgarização caracterizar-se-ia como uma confusão estilística que teria provocado dificuldades doutrinárias consideráveis nos dois milênios subseqüentes. Dentre estas dificuldades, relevante apontar que a clareza da boa-fé subjetiva, muito superior à objetiva, impor-se-ia, absorvente. ${ }^{420}$

Finalmente, a evolução do bonum et aequum e da aequitas levaria ambos, de expressões técnicas a principios de grande extensão, acabando por mesclálos com a noção de bona fides. Esta passava assim a traduzir também as noções "justiça", "honestidade" e "lealdade" em um processo de difusão vertical. ${ }^{421}$

Nesse passo, a diluição da bona fides clarifica-se. Tal noção - utilizada para combater o formalismo, sob o influxo de renovação material encabeçada pelo

418. A precisão técnica do Direito clássico foi pouco a pouco afetada pela propagação de formulações jurídicas desconformes com o modelo clássico, denominadas "fenômenos vulgaristicos". Estes redundam na repetição, glosa e comentário em vez de criatividade; imobilismo e rigider. em vez de maleabilidade e capacidade de adaptação a situações novas; confusão c predomínio. seja de abstração, seja de casuísmo, em vez de precisão. A multiplicação de tais fenômenos foi tamanha, na metade ocidental do Império, a partir do ano 395, que se pode falar em um Direito romano vulgar. A difusão horizontal da bonafides, nesse contexto, deve ser considerada como vulgarismo. Cf. A. M. R. MENEZES CORDEIRO, Da Boa-fe cill. (nota 5 supra), p. 131; 133.

419. Cf. G. Grosso, Buona fede cit. (nota 74 supra), p. 663; e A. M. R. MENEzes Cordeiro, Da Boa-fé cit. (nota 5 supra), p. 133.

420. Cf. A. M. R. MEnezes Cordelro, Da Boa-fé cil. (nola 5 supra), p. 134.

421. Cf. A. M. R. MEnezes Cordeiro, Da Boa-fé cit. (nota 5 supra), p. 129. A fides bona, como principio normativo tinha um caráter técnico peculiar, que a distinguia tanto da aequitas -como termo de constante comparação, aspiração e adequação do Direito, e mola operacional do pretor - quanto do bomum et aequum, o qual, em certas fórmulas (in bonum el aequum conceptae), constituía um critério para comensurar o quantum da condenação na valoração de lesões extra-patrimoniais. Cf. G GRosso. Buona fede cit. (nota 74 supra), p. 662. 
pretor, com os frutos mais significativos nos bonae fidei iudicia - vê-se reduzida a um tópico formal, miscigenado com outras referências similares e, igualmente, privadas de conteúdo. Suspensa entre as duas culturas que viriam a fundir no Ocidente, a bona fides flutua, quer ao sabor da predominância de uma ou da outras, quer de acordo com as oscilações dos elementos internos que a apóiam. ${ }^{42 ?}$

Como resultado, consoante aponta M. TALAMANCA. "il sintagma buna fides viene adoperato, nel medesimo passo, com riferimento sai a quella che sarebbe l'operatività della buona fede in senso soggetivo sia a quella che ne sarehbe, invece. la valenza oggetiva" 423

A complexidade da diluição, com fenômenos de difusão horizontal e vertical, implicou, todavia, a manutenção de sentidos técnico-jurídicos, em uma ambivalência que, para A. M. R. Menezes Cordeiro, conferiria à boa-fé uma capacidade de renovação persistente, até os dias atuais. ${ }^{424}$

V Conclusão.

Partindo da análise da fides, da bona fides e dos bonae fidei iudicia, podemos concluir sustentando, em primciro lugar, a existência de verdadeiro princípio de boa-fé objetiva no Direito romano.

A bona fides, entendida como princípio juridico de boa-fé objetiva, trazia em seu bojo uma expectativa de conduta objetiva, previsivel e adequada aos parâmetros da sociedade romana, expectativa esta que se reportava aos ideais da fides, noção ética e moral.

O desenvolvimento da fides como elemento jurídico positivo (bona fides), exigência da aceleração do tráfico jurídico de Roma à época da expansão comercial, foi o resultado do engenho dos pretores, inserindo-se no âmbito do processo formular, mais precisamente dos bonae fidei iudicia.

422. A. M. R. Menezes Cordeiro, Da Boa-fé cit. (nola 5 supra). p. 146-147; e G Grossn, Buona fede cit. (nota 5 supra), p. 663.

423. "O sintagma bona fides vem adotado, no mesmo passo, com referência seja à operatividadu da boa-fé em sentido subjetivo, seja àquela em sentido objetivo". Cf. La 'bona fides ' cit. (nota 10 supra), p. 17.

424. ('f. Da Boa-fi cil. (nola 5 supra), p. 147-148. 
Com o fim do processo formular e o aperfeiçoamento do instituto da usucapião, iniciou-se um processo de difusão horizontal e posterior diluição da bona fides, que passou na época justinianéia a ser utilizada para traduzir uma noção subjetiva de boa-fé.

Ainda que diluída, a noção de bona fides conservou seu sentido técnicojurídico de exigência de conduta de retidão, permitindo que séculos mais tarde ecoasse sua acepção objetiva nos ordenamentos jurídicos modernos.

Assim, a bona fides, por meio da recepção do Direito romano na Idade Média, portava os germes para a criação de cláusulas de lealdade e retidão nas codificações ocidentais. ${ }^{425}$

Inegável, de certo, que a tradição romanística evoluiu ao longo dos séculos, recebendo contribuições cristãs e germânicas, e sendo atingida pelos ideiais cientificadores a partir do séc. XVI. Esta evolução, cumpre apontar, trouxe relevantes implicações para a boa-fé, notadamente no que diz respeito ao resgate de sua acepção como norma de retidão e à construção das noções de boa-fé objetiva e boa-fé subjetiva. ${ }^{426}$

Não obstante, parece correto afirmar que os principais contornos da boafé objetiva moderna já se encontravam presentes no princípio da bona fides. Esta, de fato, apresentava-se como dever genérico de comportamento com retidão e lealdade nas relações jurídicas, tal qual a boa-fé objetiva contemporêna.

Também de forma análoga ao que sucede com essa boa-fé objetiva, os critérios que definiam o que deveria ser compreendido como conforme à bona fides em cada caso concreto eram supraindividuais e objetivos .. configurando um modelo de conduta esperada do bonus et diligens paterfamilias -- e mesurados pelo magistrado.

Dessa forma, há que se reconhecer que na admissão e delimitação ponderada do que, como hoje se diz, exige boa-fé objetiva, reside uma dos contribuições mais importantes e eficazes portadas pelo Direito romano. ${ }^{427}$

425. Cf. M. G. ZOZ, Il ruolo della buona fede nel contratro di transporto maritimo in Il nuolo della buona fede oggetiva nell esperienza giuridica storica e contemporanea, vol. IV. Luigi Garofalo (org.), Padova, CEDAM, 2003, p. 541; e B. BIUNDI, Contrato cit. (nota 309 supra), p. 241 e

426. A. M. R. MEnezes Cordeiro, Da Boa-fé cit. (nola 5 supra). p. 1283-1288.

427. CF. M. KASER, Römisches cit. (nuta 61 supra), p. 154. 
Ao adotar a normatização de princípio de boa-fé objetiva, o Direito brasileiro, como de resto sucedeu com os demais ordenamentos jurídicos ocidentais, seguiu o modelo da bona fides, a qual parece configurar a origem da referida normatização. $^{428}$

Com efeito, deve-se admitir que a boa-fé objetiva do Dircito pátrio. tanto em seu papel de cânone hermenêutico quanto como norma de criação de deveres e restrição de direitos. assemelha-se de forma ampla com o princípio da bona fides, $o$ qual pode ser considerado como a origem da referida norma brasileira.

Certamente. diferem os critérios que informam o que deve ser compreendido como conduta de retidão em cada uma das referidas normas, tendo em vista que são dependentes das particularidades de cada sociedade e momento histórico. De qualquer forma. parece assentado afirmar que a natureza, o conteúdo e a operatividade da boa-fé objetiva brasileira e da bona fides possuem fortes traços em comum.

A atuação da boa-fé objetiva como criadora de deveres de retidão e como critério de orientação para a interpretação e integração dos contratos pode ser compreendida como herdeira das implicações da bona fides. Ademais, o papel de limitar o exercício dos direitos subjetivos, em contraposição ao princípio da autonomia das partes, apresenta forma semelhante àquela experimentada no Direito Romano. no qual o ius praetorium teria exercido a finalidade de reforçar. corrigir e suprir o ius civile. $^{429}$

Nesse cenário. o estudo da bona fides pode fornecer valiosos elementos para a correta compreensão dos contornos da boa-fé objetiva do Direito pátrio, auxiliando a aclarar as jả referidas ${ }^{430}$ três grandes preocupações inerentes ao estudo desta norma, quais sejam o conteúdo, a operatividade e a dimensão principiológica.

Em relação à precisa delimitação do conteúdo da boa-fé objetiva, pode-se afirmar que a lição depreendida do exame da bona fides comprova que se trata de noção diametralmente distinta da boa-fé subjetiva, porcuanto se refere a uma regra de conduta, e não a um estado psicológico do sujeito. Outrossim, pôde-se constatar que a

428. Cf. Francisco Amaral, A Boa-fé cit. (nola 8 supra). p. 196: e CasomáriodasllvaPereira, Boa-fé cit. (notay supra), p. 494.

429. Cf. Francisco Amaral, A Buct-fé cit. (nola 8 supra), p. 196.

430. Cf. cap. I. 
bona fides foi criada como norma objetiva, passando posteriormente a comportar uma acepção subjetiva, em virtude de processo de diluição conceitual.

Ademais, o conteúdo da bona fides também fornece precioso auxilio para compreender a inviabilidade de aproximação entre a noção de boa-fé objetiva e outras locuções jurídicas ou ordenadores metajurídicos, como eqüidade, Ética e Moral.

No que concerne à operatividade da boafé objetiva, novamente a análise da bona fides está apta a aclarar o papel do magistrado na aplicação de tal noção. De modo equivalente à atuação do pretor nos bonae fidei iudicia, cabe ao juiz examinar as condutas efetivas das partes de uma relação jurídica para determinar se há ou não adequação aos parâmetros comportamentais esperados do bonus et diligens paterfamilias.

Finalmente, a dimensão principilógica da boa-fé objetiva do Direito brasileiro reproduz a estrutura da bona fides, ressaltando a singularidade do que deve ser compreendido como adequado à conduta de retidão da boa-fé objetiva em cada sociedade e momento histórico, compreensão esta que se completa por meio da atuação judicial.

Em sintese, parece assentado afirmar que as conclusões alcançadas no presente estudo fundamentam a tese de que a bona fides caracteriza-se como fons et origo da boa-fé objetiva do Direito brasileiro.

São Paulo, dezembro de 2004. 